\title{
PATOGENICIDADE E TRANSMISSÃO POR SEMENTES DO AGENTE CAUSAL DA RAMULOSE DO ALGODOEIRO
}

\author{
MARTA APARECTDA DE SOUZA TANAKA \\ Engenheira Agrónoma
}

Orientador: Prof. Dr. José Otavio Machado Menten

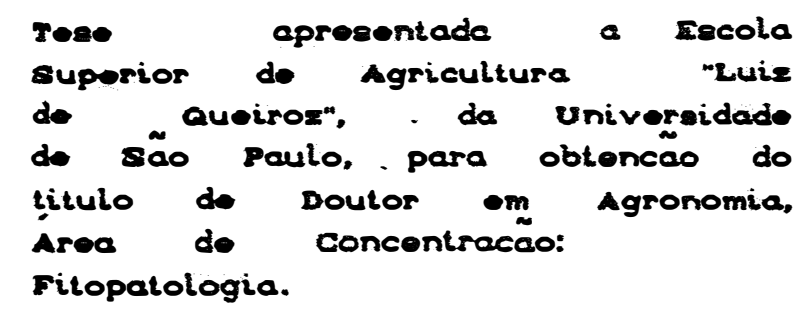

PIRACI CABA

Estado de STo Paulo - Brasil

Fevereiro - 1880 
PATOGENICIDADE E TRANSMISSATO POR SEMENTES DO AGENTE CAUSAL DA RAMULOSE DO ALGODOEIRO

MARIA APARECIDA DE SOUZA TANAKA

Aprovada em: 08/03/1990

Comissao julgadora:

Prof. Dr. Júlio Marcos Filho

Prof. Dr. Hiroshi Kimati

Prof. Dr. José Otavio Machado Menten

IACCampinas

Prof. Dr. José da Cruz Machado

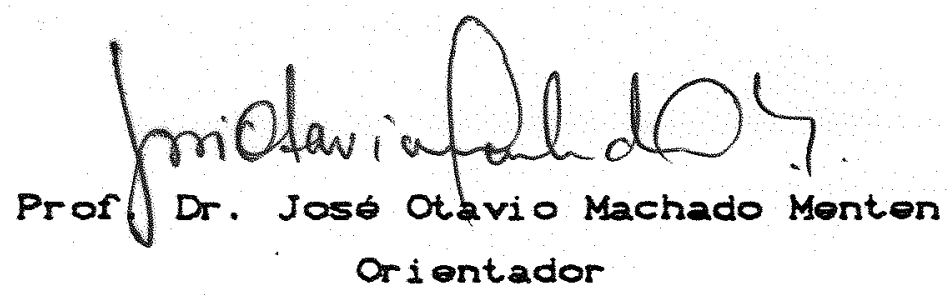


$i i i$

Ao meu esposo

Robento

- aos meus filhos

scuardo. Mancelo e reqio.

DEDICO 


\section{AGRADECIMENTOS}

- A Empresa de Pesquisa Agropecuária de Minas Gerais (EPAMIG). pela oportunidade concedida para a realização do curso de Pós-Graduação.

- Ao Departamento de Fitopatologia da Escola Superior de Agricultura "Luiz de Queiroz", por possibilitar a participação no curso de Pús-Graduação e a realização deste trabal ho.

- Ao Pror.Dr. José Otavio Machado Menten pela orientação. sugestres e incentivo.

- Ao Pror.Dr. Hiroshi Kimati. expresso, além do agradecimento pelo estimulo, apoio e amizade, minha estima e admi raçåo.

- Ao Pror.Dr. Clélio Lima Salgado. pela amizade e colaboração durante o curso de Pós-Graduação.

- Ao Instituto Agronomico de Campinas, pelas racilidades concedidas a partir do momento em que passei a integrar - seu corpo técnico. como também pelo rornecimento de sementes (Seçao de Algodãos e de 1 solados CSeção de MIcrobiologia Fitotécnicas.

- A Coordenadoria de Aperfelçoamento de Pessoal de NIvel Superior CCAPESU. pela concessão de bolsa de estudo. 
- Aos Pesquisadores Cientiricos Sergio Almeida de Moraes - Maria Angélica Pizzinatto pela revisao dos originais e valiosas sugestžes.

- Aos Pesquisadores Cientificos Toshio Igue e Roberto Tetsuo Tanaka pela colaboração na realizaça das analises estatisticas.

- A Pesquisadora Clentifica Angela Maria Cangiani Furlani pela colaboração na confecçao do "Summary".

- A todos aqueles que de alguma forma contribuiram para a realizaçăo deste trabal ho. 


\section{SUMÁRIO}

Página

LISTA DE TABELAS ......................

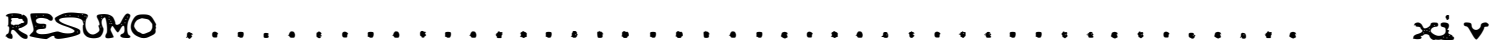

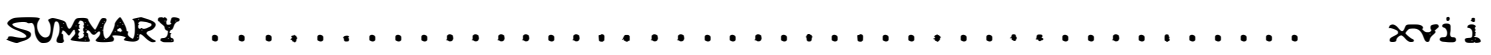

1. INTRODUÇRO ............................. 1

2. REVISTOO DE LI TERATURA ................... 4

2.1. Ocorrencia e sintomatologia da ramulose ... 4

2. 2. Importsncia oconomica da ramuloso ........ 6

2. 3. Associaçao de C. 8ossypii C. Bossypii var. cephalosporioides com as sementes de

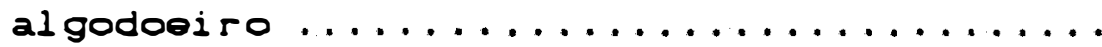

2.4. Aspectos da resistencia do algodoeiro a Colletotrichum gossypil var.

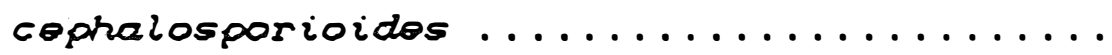

2.5. Resistencia relacionada a transmissáo de patogenos por sementes ................. 21

3. MAtERI AL E METODOS ...................... 25

3.1. Isolamento e preparo das suspensరes de co-

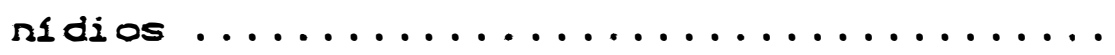

3.2. Crescimento micelial e esporulaço in vitro de C. 8ossypii var. cephalosporioidos o C.

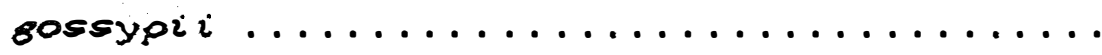

3.2.1. Crescimento micelial ............

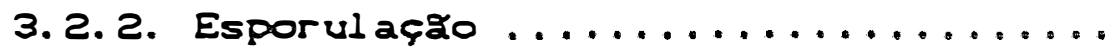


3.3. Patogenicidade de seis isolados de $C$. sossypii var. cephalosporioides em plantas de nove genotipos de algodoeiro ..........

3. 4. 'Transmissão de C. 8ossypii var. cephalosporioides pelas sementes de cinco

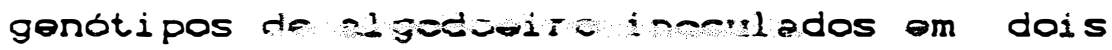
estadios de desenvol vimento ..............

3. 4.1. Análise de sanidade das sementes ...

3. 4.2. Iransmissão do patogeno semente-

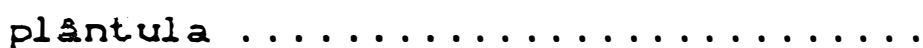

3.5. Comparação de métodos de inoculação de sementes de algodoeiro com C. 8ossypii var. cephalosporioides e C. sossypii..........

3.5.1. Métodos utilizados .............

3.5.1.1. Método 1 - Contacto das sementes com colinias dos fungos durante 24 horas $\theta$ secagem por 24 horas .....

3.5.1.2. Método 2 - Imersão das sementes em suspensão de conidios durante $30 \mathrm{minutos} \theta$ secagem por duas horas ....

3.5.1.3. Método 3 - Imersão das semontos om susponsão do conidios durante 2 horas $\theta$ secagem por 16 horas ......

3.5.2. Análise de sanidade das sementes ...

3.5.3. Emorgancia on casa do vegetaçzo ....

3.6. Patogenicidade de c. Bossypii var. cophalosporioides e C. 80ssypii a cinco genótipos de algodoeiro, através de inoculag̃o de somentes .................... 
3.6.1. Analise de sanidade das sementes...

3.6.2. Emergencia em casa de vegetaçao ....

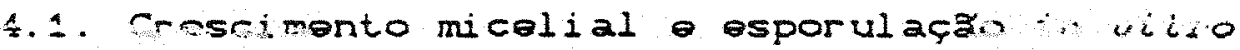
de C. sossypii var. cephalosporioidos a C.

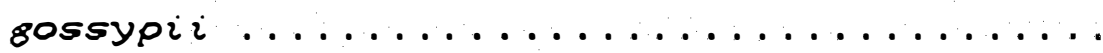

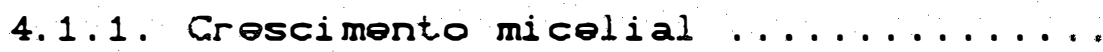

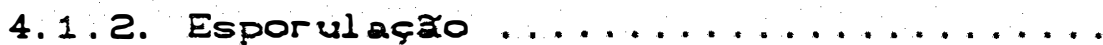

4.2. Patogenicidade de seis isolados de $C$. sossypii var. cephalosporioides em plantas de nove genótipos de algodoeiro ..........

4.3. Iransmissao de c. Bossypii var. cepralosporioides pelas sementes de cinco genotipos de algodoeiro inoculados em dois estádios de desenval vimento .............

4.3.1. Análise de sanidade das sementes...

4.3.2. Transmissao do patogeno semente-

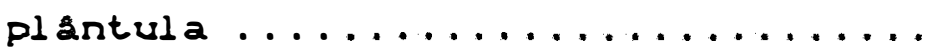

4. 4. Comparaçao de métodos de i noculaça de sementes com C. eossypii var.cephalosporioides

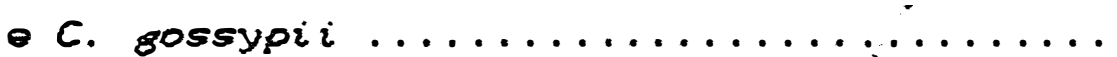

4.4.1. Analise de sanidade das semontes ... 62 4. 4.2. Emergencia em casa de vegetaçá .... 72

4.5. Patogenicidade de C. Bossypii e C. 80ssypii var. cephalosporioides a cinco genótipos de algodoeiro, através da inoculaçăo de semen-

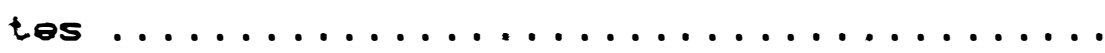

4.5.1. Análise de sanidade das sementes ... 


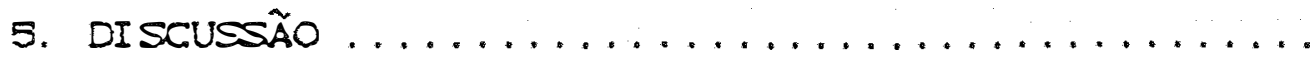

5.1. Crescimento micelial esporulaça in vitro de C. sossypii var. cophalosporioidos $\mathrm{C}$.

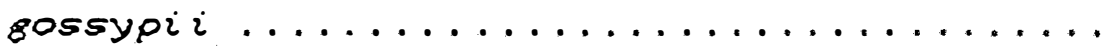

5.2. Patogenicidade de seis isolados de $C$. gossypi var. cephalosporlutdss or plantas de nove gendtipos de al godoeiro ..........

5.3. Iransmissao de C . 80ssypii var. cophalosporiodos pelas sementes de cinco genotipos do algodooiro inoculados on dois estádios de desenval vimento .............

5. 4. Comparação de métados de inoculaçåo de sementes com C. sossypii var . cephalosporiodes

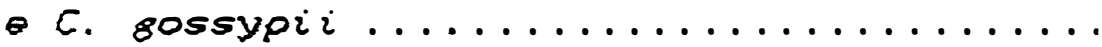

5.5. Patogenicidade de C. sossypii e C. 8ossypii var. cephalosporiodos a cinco genótipos de al godoeiro, através de inoculaça das se-

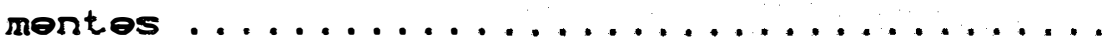

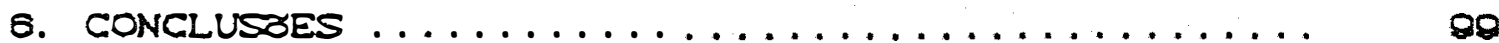

7. REFERENCI AS BI BLI OGRAFI CAS ................ 101

8. APENDICE ........................... 10 . 
1. Relaçăo dos isolados utilizados, sua procedencia e orgzo da planta de ondo roram obtidos .......

2. Crescimento micelial de seis isolados de C. sossypii var. cophalosporioidos em BDA.........

3. Crescimento micelial de seis isolados de $C$.

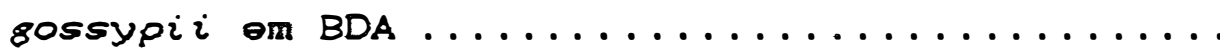

4. Esporulaçzo do sois isolados do C. goenypii var. cophalosporioides nos meios BDA o aveia.......

5. Esporulação de seis isolados de C. gossypii nos

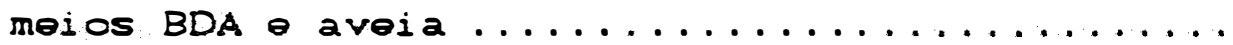

6. Reaçoes de nove genótipos de algodoeiro a inoculação com seis isolados de C. 8ossypii var. cophalosporioides, doença quantificada atraves do indice de doença CIDeo ..................

7. Indices de doença resultantes da inoculaçăo, de mistura de seis isolados de C. 80ssypii var. cophalosporioides em cinco genótipos de algodoeiro, em dois estádios de desenvolvimento....

8. Porcentagens de sementes com C. eossypii var. cophalosporioides provenientes das plantas inoculadas em dois estádios de desenvolvimento

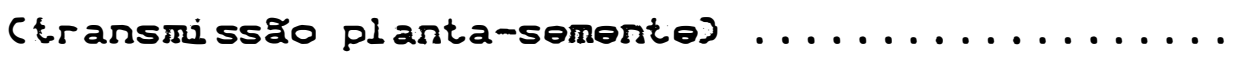

9. Porcentagens de redução da emergência de sementes provenientes de plantas inoculadas com $C$. sossypii var. cephalosporioides em dois estadios de desenvol vimento ....................... 
10. Porcentagens de plantulas sobreviventes com sintomas, provenientes das sementes de plantas inoculadas com C. sossypii var. copralosporioides em dois estádios de desenvol vimento CTransmissá

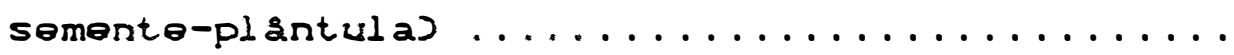

11. Porcentagens metize de t.ransmissao de C. gossypii var. cephelosporioides pelas sementes de cinco genótipos de algodoeiro, cujas plantas-må foram inoculadas em dois estádios de desenvolvimento.

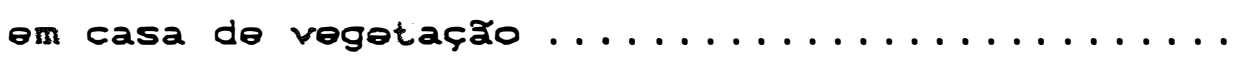

12. Porcentagens de sementes do cultivar CNPA-2H com C. sossypii var. cephalosporioides, resultantes da inoculaçao com o método 1 - contacto com das sementes com culturas do fungo durante 24 horas

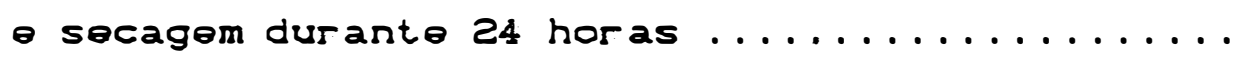

13. Porcentagens de somentes do cultivar CNPA-2H com c. gossypii vas. cephelosporioides resultantes da inoculaça com o mbtodo 2 - imorsao das somentes na suspensáo de indculo durante $30 \mathrm{minu-}$

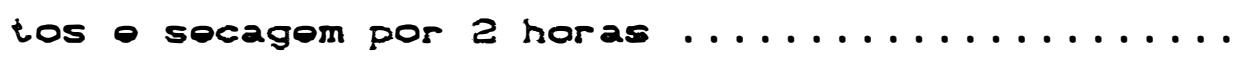

14. Porcentagens do somentes do cultivar CNPA-2H com c. sossypii var. cephalosporioides resultantes da inoculaça com o método 3 - imersá das sementes na suspensao de esporos durante 2 horas

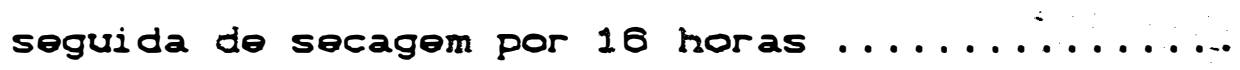

15. Porcentagens de sementes do cultivar CNPA-2H com c. sossypii var. cophalosporioidos, inoculadas com 3 diferentes métodos, com ou som assepsia

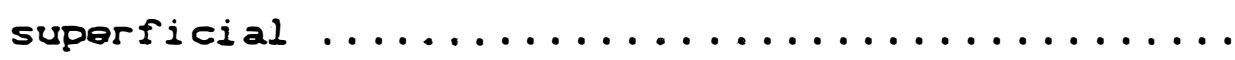

16. Porcentagens de sementes do cultivar CNPA-2H com c. sossypii, resultantes da inoculaça com o metodo 1 - contacto das sementes com culturas do fungo durante 24 horas e socagem durante 24 ho-

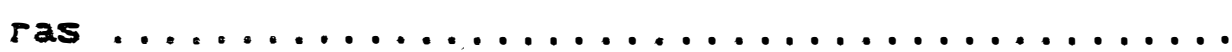


17. Porcentagens de sementes do cultivar CNPA-2H com C. sossypii, resultantes da inoculaça com o motodo 2 - imersao das sementes na suspensão de inoculo durante 30 minutos secagem duas

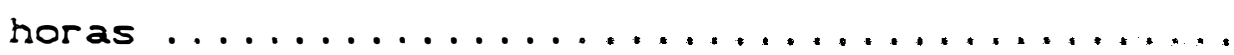

18. Porcentagens de sementes do cultivar CNPA-2H com C. 8ossypii, resultantes da inoculaçzo com o método 3 - imersao das sementes na suspensao de inoculo durante duas horas seguida de secagem 16

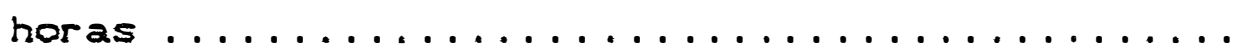

19. Porcentagens de sementes do cultivar CNPA-2H com c. sossypii, inoculadas com 3 diferentes mótodos, com ou sem assepsia superficial ..........

20. Porcentagens de plantulas sobreviventes com sintomas o roduç̃o da porcontagom do omorgoncia om casa de vegetaçăo, resul tantes da i nocul açăo das somortos do cultivar CNPA-2H, com C. Bossypii var. cephalosporioides, utilizando 3 diferentes

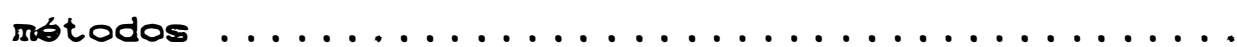

21. Porcentagens de plantulas sobreviventes com sintomas e redução da porcentagem de emergencia em casa de vegetaçao, resul tantes da inoculação das sementes do cultivar CNPA-ZH, com C. gossypii, utilizando 3 diforentes métodos .............

22. Porcentagens de sementes mortas, radiculas apodrecidas e incidoncia total de C. sossypii var. cophalosporioides a C. 8ossypii en cinco genótipos de algodoeiro, resultantes da inoculaçăo das sementes pelo método $3 \ldots . . . . . . . . . .$. 
23. Porcentagens de plantulas sobreviventes com sintomas e de redução da porcentagem de emergencia em casa de vegetação, resultantes da inoculação das sementes de cinco genotipos de algodoeiro com C. gossypit var. cophalosnorioidos o to. gossypii, utilizando o motodo $3 \ldots \ldots \ldots$ 
PATOGENICIDADE E TRANSMISSÃO POR SEMENTES DO AGENTE CAUSAL DA RAMULOSE DO ALgODOEIRO

\author{
Autora : MARIA APARECIDA DE SOUZA TANAKA \\ Orientador : Dr. JOSE OTAVIO MACHADO MENTEN
}

RESUMO

- presente trabalino fol realizado nos laboratórios e na casa de vegetaça do Departamento de Fitopatologia da Escola Superior de Agricultura "Luiz de Queiroz". da Universidade de Sa Paulo.

Foram conduzidos experimentos objetivando elucidar alguns aspectos relacionados com a transmissáo de C. gossypil var. cephalosporioides pelas sementes de algodoeiro e comparar os danos em sementes e plantulas com aqueles provocados por C. sossypii.

A patogenicidade dos 1 solados de C. gossypi $i$ e C. gossypii var. cepralosporioides rol correlacionada com a sua esporulação, porem não com o seu crescimento linear. em meio de cultura.

Verificou-se a existencia de variabilidade genetica entre os 1 solados de C. sossypiz var. cephalosporioides, avaliada pela reaça dos direrentes genotipos testados. Evidenciou-se a ocorrencia de raças 
virulentas do patógeno e resistência vertical incompleta do hospedeiro. caracterizadas pela impossibilidade de ordenamento dos isolados em relação aos genótipos e destes em relação aos isolados, aliada a presença de interaçăo direrencial significativa entre eles.

Em experimentos sobre a transmissão de $C$. gossypil var. cephalosporioides pela semente de cinco genótipos de algodoelro. inoculados em dols estádios de desenvol vimento, verificou-se que, embora a inoculação aos trinta dias após a semeadura tenha resultado em maior severidade da doença, a incidencla do patógeno nas sementes fol malor quando a inoculaçăo fol efetuada em plantas com maçăs formadas. Estas sementes aprosentaram maiores porcentagens de redução da emergencia e de plântulas com sintomas. Verificou-se que C. gossypii var. cephalosporioides rol transmitido pelas sementes dos diferentes genótipos em taxas que variaram, em média, de 49 a 70\%, respectivamente para os genotipos EPAMTG-3 e Nu15-79/117. Nem sempre a resistencia do genotipo na rase adulta fol correlacionada com a incidencia do patogeno na semente e a resistencia no estádio de plantula.

Foram comparados os danos em plantulas provocados por C. sossypii e C. gossypil var. cepralosporioides, atraves da inoculação das sementes por tres diferentes métodos. Verificou-se que o ereito dos 
dols patógenos sobro os parkmetros avaliados variou em função do isolado utilizado. A efíleincia dos métodos testados na obtençăo de sementes infectadas. variou de acordo com a técnica empregada. O método do contacto das sementes com colónias do fungo durante 24 horas. seguidas de secagem por 24 horas. roi considerado o mals eficiente. 


\author{
Author: MARIA APARECIDA DE SOUZA TANAKA

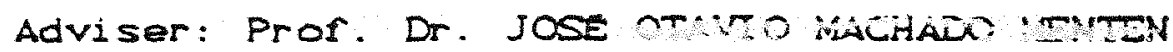

\title{
SUMMARY
}

The present investigation was carried out at the laboratories and greenhouse of the Department of Plant Pathology of Escola Superior de Agricultura "Lulz de Queiroz". University of Sao Paulo. Brazil.

Experiments were conducted with the objective of explaining some aspects concerned to seed transmission of C. sossypii var. cephalosporioides and to compare the damage caused by this pathogen to that caused by $C$. sossypii.

The results showed that the pathogenicity of C. Bossypii and C. Bossypii var. cephalosporioides isolates was correlated with their sporulation. but not with their 1 inear growth.

Tests of pathogenicity demonstrated the extstence of genetic variability among the $C$. gossypii var. cephalosporioides isolates when inoculated in different cotton genotypes. On the other hand. the 
genotypes varied in their reactions to the isolates.

Bhere was evidence of occurrence of virulent races of the pathogens and vertical incomplete resistance of the hosts, characterized by the impossibility of ranking the lsolates in rill ton to the toutypes and vice versa, and by a statistically significant differential interaction among them.

Experiments on seed transmission, with Ilve cotton genotypes inoculated with $C$. gossypil var. cephalosporioides at two growth stages, showed that the incidence of the pathogen was higher on seeds from plants inoculated at the boll stage. Neverthless, the highest disease severity resulted when inoculation was done thirty days after sown.

c. sossypit var. cephalosporioides was transmitted by seeds of the different genotypes in rates that ranged from $48 \%$ cror the most resistant EPAMIG-3 genotypes to $70 \%$ (most susceptible. Nu-15-79/1172. Also adult plant resistance was neither correlated with the pathogen incidence on the seads nor "with seadling resistance.

Seed Inoculation with C. gossypii and $C$. sossypii var. cephalosporioides by three different methods. was used to compare sedling damage. which severity varled as a runction of the isolate. Seed infection efriciency 
$x i x$

was also tested by the three methods and varied with the technique applied. The method that consisted of the sood contact with the rungi colonies during 24 hours followed by 24 hours air drying. was considered the most efricient. 
1. TMTRTuctó

A cultura do algodoelro CGossypiun hirsutun L. var. Latifolium Hutchl ocupa lugar de destaque no Brasil. não só por produzir a mals importante fibra text11 natural. mas também pelos diversos tipos de aplicaçăo de seus sub produtos.

Vários fatores podem interferir na produtividade do algodoeiro e. dentre eles. são cltadas inúmeras doenças causadas por fungos, bacterias, virus e nematóldes, que săo responsávels anualmente por enormes perdas (KIMAII. 1980; WATKINS, 1981 ).

Dentre as doenças de origem rúngica, a ramulose tem sido considerada uma das principals, causando em certos anos prejuízos da ordem de 20 a 30\%, podendo ascender a 85\% em casos extremos CCIA, 1977 ; KIMAII, 1980 s.

A doença, causada pelo fungo Colletotrichun gossypii South. var. cophalosporioides A.S. Costa e constatada pela primelra vez no Estado de Sto Paulo, no ano agricola de 1935-36 CCOSTA \& FRAGA JUNIOR, 1939), tem ocorrido com severidade, principalmente nos Estados do Hordeste e Minas Gerals, notadamente no Triangulo Mineiro. 
Nesta última regiao. embora de ocorrancla esporádica. quando as condl çres climaticas săo favorávels a sua manifestaçăo, os prejuizos são bastante acentuados CLIMA. 1981 ; IANAKA, 19820.

A possibilidade de trarenussão pelas sementes, demonstrada por COSTA (1939). LIMA (1981) e LIMA et al11 (1885). dentre outros, Iaz com que a distribulço das sementes produzidas em campos onde fol constatada a doença se constitua num risco de dissemi naçăo do patógeno. Essa disseminação podo aumentar o inoculo o. consequentemente, a incidencia da ramulose em locals onde ela já ocorre ou, o que é mals grave, levar o patogeno para áreas ainda 1 sentas.

Em consequencia disso, a escolha e adocáo de medidas de controle terá malor probabilidade de ext to se baseadas no conhecimento dos varios aspectos relacionados com a transmissăo pelas sementes. considerando tamborm a variabilidade genética do fungo quanto a patogenicidade.

A grande semelhança morfologlca, assim como os sintomas de tombamento produzidos por colletotrichum gossypii South. agente causal da antracnose, $e c$. eossypii var. cephalosporioides, não têm permitldo a ldentificação precisa desses patógenos quando incidem em sementes ou plantulas de algodoelro (COSTA. 1939 . Somente a inoculação das sementes pelo patogeno 1 dentificado pode garantir a assoclação da sintomatologia apresen- 
tada com o verdadelro agente causal.

Assim. os objetivos do presente trabalho roram:

$$
\text { - Avaliar o crescimento micelial. a }
$$

esporulaçăo in vitro e a patogerícicadio vie difentes isolados de C. gossypii e C. sossypi var. cepralosporioides.

- Avaliar a reação de diversos genótipos de algodoelro à l noculaçăo de varios lsolados de C. gossypit var. cepralosporioides.

- Estudar a transmissáo planta-semente e se mente-plantula de C. Bossypii var. cephalosporioides em al godoeiro.

- Comparar tros mótodos de i nocul ação de se mentes de algodoelro com C. Bossypii e C. Bossypii var. cephalosporioides quanto a eficiencia na obtenção de semen tes infectadas. 
2. REVISÃO DE LITEPATUR

2.1. Ocorrência e sintomologia da ramulose.

A ramulose ou superbrotamento fol observada pola primeira voz no Brasil no municlpio de Rancharia. Estado de Szo Paulo, em 1035 (COSTA \& FRAGA JUNIOR, 1037 ). Esses autores menclonaram que a doença fá havia sido constatada na "Cotton Research Station". em Trinidad e Tobago. no ano de 1927.

Inicialmente, a ramulose fol considerada como sendo causada por virus. devido a sintomatologia CCOSTA \& FRAGA JUNIOR, 1037). MaIs tarde, COSTA \& FRAGA JUNIOR (1939) identificaram o fungo Colletolrichum 8ossypii South. var. cephalosporioides como o agente causal da ramulose.

No Brasil, a doença já fol relatada também nos estados de Pernambuco. Paralba. Rio Grande do Norte. Pará (ABRAHZO \& COSTA, 1040), Bahla (CIA, 1077), GOlas CCARVALHO, 1971 ; CIA et al11, 1982b). Ceará (ARAUjo et al11. 1878). Minas Gorals (LIMA, 1081; IANAKA, 1082), Mato Grosso do Sul e Paraná (CIA et al11. $1082 b$ ). 
MALAGUTII (1855) constatou a sua ocorroncla na Venezuela, denominando-a de "escobilia". No Paragual fol constatada por MATHIESON \& MANGANO (1985). Incldindo sobre o cultivar de algodoeiro Reba P270. LIMA et alli C:S3E: mencionaram a sua ocorroncia tamberm na Bol I via.

os principals sintomas observados numa planta com ramulose são : ramiricação excessiva, altura sempre abalxo da normal. Internodlos curtos, contorcidos. nós 1ntumescidos. ramos com manchas pardacentas de rorma alongada. Fol has com lesbes necroticas alongadas, arrodondadas ou angulares, as vezes na nervura. Os tecidos mortos - secos das leszes rollares podem se desprender, del cando perfuraçZes de forma estrelada CABRAHKO, 1881 ; ABRAHKO \& COSTA, 1849; COSTA \& FRAGA JUNIOR, 1937; 1939; TOFFANO \& SILVIRA, 1 (284).

A doença pode se manifestar em qualquer idade da planta, porém as perdas tendem a ser malores se a infeção ocorrer nos estádios inictals do seu desenvolvimento. So a infeç̧a ocorrer em plantas ja desenvolvidas (ramulose tardia). geralmente os prejulzos são menores CABRAHAO. 1052; 1861 ; ABRAHAO \& COSTA. 1049; CIA, 18775. porque as maças ja estarão quase todas rormadas e o rungo ataca de preferencia as partes ma1s novas (broto apical), em crescimento ativo. 
2.2. Importância econômica da ramulose.

A ramulose é uma doença esporádica,que pode causar sérios problemas em determinados anos agricolas.

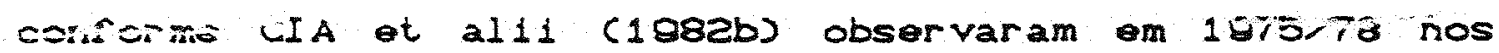
estados do Paraná. Minas Gerals e Golás, sem muita gravidade, atualmente, no estado de Sra Paulo.

A doença ja rol considerada uma das mais 1 mportantes do estado de Sra Paulo, onde ocasionou severos danos. No periodo de 1848 a 1852 os prejulzos causados foram elevados, girando em torno de 20 a $30 \%$, chegando.em alguns casos, a 85\% CABRAHZO, 1952 ; ABRAHZO \& COSTA, 1949; CIA. 1877 ). Segundo CIA (1877),a substitulçăo da variedade IAC-11, altamente suscetivel, por outras mais resistentes ou tolerantes, tornou a ramulose de 1 mportáncia secundária para o estado. No entanto, a doença pode se tornar novamente severa, devendo ser considerada nos trabal hos de mel horamento CCIA, 1977 ; KIMATI, 1980 s.

Dependendo das condiç̧es climaticas e da suscetibilidade da variedade. a produçáo, de modo geral, pode ser fortemente dimf nuIda ou quase nula. COSIA \& FRAGA JUNIOR (1837) O TOFFANO \& SILVEIRA (1864) consideraram que. devido a tendéncla da doença generalizar-se numa plantação, ela e capaz de causar prejulzos ás vezes totals, tornando a cultura do algodoeiro anti-economica. Sam recelo de exagero, onde ela ocorre constitul-se no 
fator que ocasiona os mals elevados prejuizos.

A ramulose, ultimamente, tem sido considera da de grande importancla em alguns estados do Centro-Sul e do Nordeste do Brasil, principalmente em anos de elevada precipitação pluvial (CARVALHo et aiji. 1884; 1986 ). Se ocorrer alta infecça durante os primeiros 30 dias de idade das plantas, estas ficam praticamente improdutivas CCARVALHO et al11, $1881 \mathrm{bJ}$.

CARVALHO et al11 (1886) ressaltaram a 1 mportancia que a ramulose tem assumido no Nordeste do Brasil, onde tem ocorrido em varias localidades. A doença vem merecendo multa atençăo por parte dos melhoristas. que tóm procurado incorporar ás varledades gens de resistencia não só a outros patógenos, mas tambóm à $C$. sossypii var. eepraiosporioides.

\section{LIMA Ot 2111 (1084; 1085) O CARVALHO Ot} al11 (1885) referiram-se a ramulose como uma das principals doenças da cultura do algodoelro no Brasil. Embora não ocorra normalmente com grande intensidade, quando as condiçes climaticas são favorávels, chega a causar grandes perdas.

As perdas se tornam particularmente 1 mportantes quando a infeccão ocorre em plantas alinda novas. Neste caso, a morte do broto apical, que estimula as gemas axilares a rormarem número excessivo de galhos. provoca um esgotamento das reservas em detrimento da carga 
de capulhos, que pode ser nula em multas plantas CABRAHÃO. $1852 ; 1861 \mathrm{~J}$.

ARANTES et ali1 (1988) relataram incidencia severa de ramulose em experimentos conduzidos em Mato Grosso no ano agricola $1803-60, "$ sendo que as melhores plantas receberam nota 3 , na escala visual de 1 a 5. crescente para severidade. Em tals circunstancias.a doença mostrou-se limitante para a cultura, sendo questionável a conventencia de se plantar algodáo com qualquer das? variedades estudadas CCNPA-2H, CNPA-3H, IAC-17. IAC-10. IAC-20, I APAR-4-PR-1 E EPAMI G-32.

Em estudos realizados em dols anos agricolas sobre a influencia da ramulose nas caracteristicas de ribra e produçăo do algodoeiro. verirlcou-se que a doença afetou a produtividade, peso do capulho, Ilnura, micronalre, comprimento, uniformidade e porcentagem de ribra, al ém do peso de 100 sementes. As reduçชes de produtividade foram de $33,19 \% \mathrm{em}$ um ano e $46,14 \%$ no outro (CARVALHO et al11. 1884 ).

2.3. Associação de C. gossypii e C. gossypii var. cepralosporiodes com as sementes de algodoeiro.

C. gossypii var. ceprolosporiodes encontrase associado ás sementes do algodoelro, sendo estas consideradas a principal vila de disseml naçăo do patógeno. Esta 
assoclaçăo pode ser lanto externa, na forma de esporos (conidios), ou interna, na forma de micello dormente CKIMATI , 1980; LINA et al11. 1985; 1988). A semente portadora do fungo constitui-se em inóculo prímário da doença. al ém do solo contaminado, servindo as leszes das plantulas e plantas infectadas como fonte de inbculo secundario CKIMATI , 1980 ).

COSTA (1839). rol o primeiro a demonstrar a possibilidade do patogeno ser transmitido pelas sementes. Utilizando sementes inoculadas artificialmente com C. 8ossypit, agente causal da antracnose, $\theta$ C. gossypii var. cepholosporioides, foram observadas diferenças na reação das plantas a cada um dos patogenos. Embora ambos causem tombamento. rol relatado que no caso de C. gossypii var. cephelosporioides a manifestaça dos sintomas mals ráplda. Posteriormente, apenas as plantas com C. 8ossypii var. cepralosporioides extbem sintomas de superbrotamento. Mals tarde, COSTA (1941) coneluiu que o número de sementes que carregam o patogeno em lnfeção natural não multo pequeno. sendo mal of que $1 \%$ em multas amostras colhidas de plantas doentes.

A 1 mportancia da transmissão pela semente rol cltada em várlos trabalhos CABRAHZO, 1852; 1881; ABRAHÃO \& COSTA, 1949; TOFFANO \& SILVEIRA, 1984; MALAGUTII, 1855 ; FOLLIN \& MANGANO. 19832.

Experimentos de campo foram reallzados por 
LIMA et al11 (1885) sobre o transporte e a transmissibllidade de C. sossypii var. cephalosporioides através da semente de algodoelro, em relaçăo ao estádio de desenvolvimento da planta na ocasiăo da infecçăo. As plantas foram 1 noculadas em quatro epocas distintas: aos 35 dias apos o plantio, quando a maloria das plantas emitiu botzes rlorals, estava com as flores abertas e com as maçás completamente desenvolvidas. Os resultados mostra ram que : a) houve uma relaçăo entre a porcentagem média de sementes portadoras do patógeno e o estádío desenvol vimento da planta inoculada; bJ quando a infeç̧ăo ocorreu nas plantas com maçăs desenvolvidas, o número de sementes - de amóndoas com o patógeno fol significativamente malor do que quando a infecção ocorreu nos demals estádíos de desenvol vimento da cultura; es năo houve correlaçăo entre - grau de severidade da doença e a porcentagem de sementes portadoras do patógeno.' Constatou-se ainda que o fungo fol encontrado tambem no interior da amendoa, em porcentagens que variaram de 0,4 a $2,0 \%$. Esses resultados foram conside rados como consequéncla da penetração do patógeno através da maçă. atingindo desse modo a semente. Essa suposição rol baseada no rato de se ter lsolado o patógeno de peque nas lesóes encontradas na superficle das maças.

PIZNATTO et al11 (1988) realizaram estudo sobre a transmissão de C. eossypii var. cephalosporioides utilizando sementes de 4 cultivares inoculados em 
condiçres de campo. O experimento fol 1 nstalado com 3 tipos de sementes : Inrectadas e desilintadas com ecido sulfúrico, Infectadas e deslintadas mecanicamente e sementes procedentes de campos isentos de ramulose. A taxa de i. ansmissao verificada variou de 0,58 a 3,36 , sendo malor para o genotipo mals suscetlvel, a 11 nhagem Nu-15-79/117. Foram atribuidas notas de 1 a 5 a todas as plantas da parcela. em duas avaliaçóes realizadas aos 100 e 120 dias após a emergencia. A porcentagem de plantas com sintomas na segunda avaliação pol malor do que na primeira. para os 4 genótipos, o que demonstra ter havido disseminaçao eflalente do fungo. mesmo para o genotipo mals resistente, EPAMIG-3, a partir do inoculo inicial transportado pelas sementes.

\section{LIMA et al11 (1988) demonstraram que $C$.} 8ossypii var. cepholosporioides pode sobreviver na semente de algodoelro com linter, com grau de umidade em torno de 12 a 13\%, armazenadas em condlç8es ambientes, com uma varlaçáo de temperatura de 16,8 a $33,0^{\circ} \mathrm{C}$, ate aos 12 meses de armazenamento. Aos 14 meses nestas condlços o patogeno já năo se encontra viável na semente. Os autores consideraram que. possivelmente, em temperaturas mals baixas - patógeno consiga sobreviver por um periodo mals longo. 0 que esta de acordo com os resultados de ARNDT C1946: $1=2=$ com c. Bossypii. ARNDT (1946) observou a sobrevivencia do fungo em sementes com grau de umidade de 
8. 10. 12. 14 e 16\%, armazenadas por 5 anos $\theta$ meio. Em sementes de algodoelro armazenadas com grau de umldade de $14 \%$. C. gossypii sosre uma reduçăo drástica na sua viabilidade. após 12 meses de armazenamento CARDNT, 18463 . Resuilados semelhantes foram obtidos por LUDWIG (1924) e LIMA et al11 (1988). que observaram a malor reduçå na porcentagem de sementes portadoras de C. sossypii e C. Bossypit var. cepralosporioides, respect1vamente, aos 12 meses de armazenamento em condlç̧̋es amblentes de laborator 10 . LIMA et alil (1888) relataram alnda que, aos 14 meses de armazenamento, a porcentagem de germlnaçao das sementes estava em torno de 31,5\%, e que,portanto, a viabilidade do patogeno rol menor do que a da semente.

Nos resultados de testes de sanidade de sementes de algodoeiro apenas se relata a presença de $C$. sossypii. e năo C. gossypii var. cephalosporioides, embora ambos possam estar ocorrendo. A grande semelhança morfologlca entre os dois fungos não tem permitido distingui-1os.

Tanto C. sossypii como C. sossypii var. cephalosporioides são considerados dentre os mals Importantes economicamente em estudos de patologia de sementes de algodoelro (PIZINATTO. 1987). Ambos podem causar sorlos problemas na germinaça. como falhas no "stand". necessidade de replant10, que leva por sua vez a 
despesas com måo-de-obra, maquinaria, etc. além de se perder a época recomendada para o plantio. No entanto, a ramulose reveste-se de importancia malor. devido as perdas que ocasiona a produçăo. Por esta razăo, e pelo rato das sementes se constitutrem no principal velculo de i sseminação do patógeno. é necessálo que se dedique esfacial atenção à ramulose.

$\mathrm{Na}$ reallzaçżo de estudos envol vendo a ramulose, muitas vezes torna-se necessário lançar măo da Inoculaçăo de sementes, o que garante a certeza de se estar trabalhando com C. Bossypii var. cepralosporioides e năo C. sossypii.

Varios mátodos tom sido utilizados para 1 nocul ação de sementes com esses dols patógenos.

COSTA (1939), ut111zando sementes deslintadas com acido sulfúrico, inoculou-as pelo contacto com coIontas de C. Bossypii e C. gossypi var. cephalosporioides. crescidos em melo de agar em tubos de ensalo. As sementes foram introduzidas nos tubos, sendo estes agitados várias vezes para que as mesmas tocassem nas colonias, o que faci iltou a adesão dos esporos. Logo após a infestaçao, as sementes foram semeadas em vasos de barro. Por esse método o autor obteve sucesso, conseguindo sintomas de tombamento e transmissão do rungo para as plántulas sobreviventes.

Estudando o erelto do potencial de inóculo de cossypit sobre o tombamento de mudinhas de 
algodoeiro. BALMER et al11 (18B8) 1 nocularam as sementes. deslintadas com ácido sul úrico, colocando-as em suspensão de conldios, em agl taçăo, durante 30 minutos. As sementes Inoculadas foram semeadas em vasos de barro e os autores obt1ve:an siniomas de tombamento em plantulas. Foi observado alnda. que existem diferenças em patogenicldade entre os isolados testados. evidencladas quando roram ut1l1zadas as concentraçôs mals balxas de inóculo. Essas diferenças entre 1 solados tendem a diminuir nas concentraçoes mais elevadas. o que deve ser considerado em trabalhos que ut 111 zem tal técnica.

$$
\text { HALFON-MEIRI \& VOLCANI (1977) também }
$$

ut1lizaram a técnlca de 1 mersão das sementes em suspensão de esporos de C. gossypiti. Os melhores resultados foram obtidos pela 1 mersão de 100 sementes em $100 \mathrm{ml}$ de suspensão de $2 \times 10^{5}$ esporos $/ \mathrm{ml}$. durante 3 horas, a temperatura de $20-25^{\circ} \mathrm{C}$. Nestas condl çes, cerca de $80 \%$ das sementes inoculadas deram or 1 gem a plântulas com sintomas típlcos da doença. quando semeadas em arela estêril.

Em experimento sobre a variabilidade de $C$. sossypi $i$ var. cephalosporioides e avallaçăo da resistêncla de linhagens de algodoeiro a ramulose. LIMA (1881) utilizou. para inocular sementes, uma suspensão de esporos na concentração de $10^{4}$ consdios/ml. Em cada erlenmeyer contendo a suspensão de esporos foram colocadas 32 sementes deslintadas com ácido sulfurico e em seguida 
agitadas durante $5 \mathrm{minutos.} \mathrm{As} \mathrm{sementes} \mathrm{inoculadas} \mathrm{foram}$ semeadas em sacos plásticos contendo solo esterilizado com brometo de metila, em casa de vegetaçăo. A avallação do grau de infecção foi efetuada 15 dias após a semeadura. por melo de uma escala de notas constitulda aus graus 0 (zero). 0.5 e 1.0. crescente conforme a severidade dos sintomas.

Para estudar o efelto de C. Bossypit e $C$. gossupii var. cephalosporioides em plantulas, FOLLIN \& MANGANO (1883) inocularam sementes de algodoelro pela 1 mersão das mesmas durante duas horas em uma suspensão de $10^{2}$ esporos $/ \mathrm{ml}$ de cada um dos dols patógenos. Antes da semeadura em vermiculita embebida em sol uçăo mineral nutr tiva as sementes foram postas a secar durante 12 horas. As plântulas mortas foram contadas aos 6,8 e 10 dias após a semeadura. No décimo dia as plantulas sobreviventes foram arrancadas e avaliadas. O experimento fol realizado a $25^{\circ} \mathrm{C}, 80 \%$ de umldade relativa e alternancia dia-noite de $12 / 2$ horas. Os autores observaram que a mortalidade se iniciou depols da germinação e fol mals ráplda e mais severa em C. gossypit, que fol, portanto, considerado mals agressivo. Esses resultados contrariam aqueles observados por COSTA (1838), que relatou ter verificado uma manffestaçăo de sintomas mals rápida para C. Bossypii var. cephalosporioides. Possivelmente esses resultados possam ser devidos as diferenças entre os isolados utilizados 
pelos autores, constitulfăo genetica dos cultivares e condif̧es ambientes. FOLLIN \& MANGANO (1883) observaram alnda que a inoculaçăo com $C$. sossypii originou menor número de plantulas sobreviventes $(2.6 \%$. enquanto que para C. gossypii var. cephalosporisudss esse número rol de 34.1\%, encontrando-se multas plantulas aparentemente sadias. Das plantulas sobreviventes a inoculação com $C$. gossypit var. cephalosporioides, $88.5 \%$ apresentaram necrose no colo, mas so $42,4 \% \mathrm{com}$ severidade. Por outro 1ado. naquel as sobreviventes a inoculaçăo com $C$. bossypi rol observada forte necrose no colo, que provavelmente as levaria a morte.

C. gossypit var. cephalosporioides rol 1 noculado com oxito em sementes de algodoelro do cultivar CNPA-2H, com linter ou deslintadas com ácido sulfúrico. mediante o contato das mesmas com colonias do fungo desenvol vidas durante 8 dias em melo de BDA, em placas de Petri (TANAKA et al11, 1887). Foram testados diferentes periodos de permanencia das sementes em contato com 0 1nbculo. ou seja. O (zeros. 12, 24, 38 e 48 horas. A avallação fol felta atraves de um teste de sanidade pelo metodo do papel de riltro com as sementes submetidas ou råo a assepsia superficial com hipoclorito de sodso. Observou-se. de modo geral, um aumento gradativo do erelto do patógeno sobre as sementes. a medida em que se aumentou - tempo de exposição ao inoculo. Paral el amente observou-se 
um menor erelto da assepsia superficial em funço do aumento do tempo de exposição. Indl cando que o contato das sementes com o lnoculo, a partir de 12 horas. resultou em infecção, com a penetração do fungo no interior da semente. Comparando as janjentes com linter as deslintadas. verificou-se que nas primelras o linter deve ter dificultado a penetraçăo, uma vez que a assepsia teve malor erelto sobre essas sementes.

2.4. Aspectos da resistência do algodoeiro a Colletotrichum gossypii var. cephelosporioidos.

Assim como para multas outras doenças. pode-se considerar o uso de cultivares resistentes ou tolerantes ao patogeno como o melo mals eficiente e económico de controlar a ramulose CCIA. 1877 ; CARVALHO et al11, 1988; LIMA et al11. 1984; 19862.

cOSTA (1841) relatou os primeiros trabal hos relacionados com a resistancla a ramulose, observando que a maloria dos cultivares testados comportaram-se como suscetl vels ao patógeno.

CIA (1877) comenta que em G. hirsutum rol observada variaç̃o quanto ao ataque de ramulose, o que mostra a viablildade de se razerem seleçós para resistenc1a.

Em consequencia da ramulose vir atingindo 
nivels quase epldemlcos em algumas regibes produtoras do Brasil. Intensificou-se recentemente o número de trabalhos de melhoramento buscando fontes de resistencla ao patógeno. como uma manelra de controlar a doença CLIMA et 2111,1884 .

CIA et al11 (1982a) consideraram de grande 1 mportancla a linclusão da ramulose nos ensaios visando obtenção de 1 inhagens resistentes as principals doenças do algodoelro no estado de Sro Paulo. Os materials geneticos em fase adlantada de melhoramento são testados anualmente para resistencla, al ém da ramulose, a murcha de Fusariun. mancha angular, murcha de Verticilliun e nematoldes. As médlas dos resultados obtldos apresentaram, em destaque. os materials IAC-17. IAC-17-727 e Mi nas Dona Beja como os mals resistentes. sendo que IAC-18 e IAC-19 comportaram-se como tendo resistencla lintermediária.

CARVALHO et al11 (1881a) O LIMA et al11 (1984), em trabalhos real1zados no CNP-Algodzo em Camplna Grande, PB, relataram que o cult1 var IAC-17. devido ao seu comportamento em campo, pode servir como testemunha resis tente, em trabalhos de melhoramento visando resistencia a ramul ose.

Tendo em vista a 1 mportancia da doença. CIA et al11 (1982b) Intciaram, no ano agricola 1981 ra, estudo com Inoculação artificial do patógeno, no qual testaram 18 materials genéticos. Embora a lncidencla da doença tenha 
sido relativamente fraca. os dados mostraram que os materials orlginados do cultivar IAC-17 foram relat1vamente melhories que a linhagem Nu-15-79/117, a testemunha suscet1 vel.

Irabalhos reallzados com ganotipos de algodoelro. do Banco de Germoplasma do Centro Nacional de Pesquisa de Algodzo CCNPAEMBRAPA. permitiram observar que houve acentuada varlação no nlvel de resisténcia ao patogeno. Esses trabal hos foram real 1 zados com 1 noculaç̧es artificials das plantas em casa de vegetação. durante os anos de 1881 e 1882. Dentre os materials testados nos dols ensalos. a 11 nhagem HR $21 T 16$ fol a que apresentou major nivel de resistencia. Essa linhagem resultante do cruzamento entre os cultivares 542 e Texas 16 CLIMA et al11. 18843

LIMA et al11 (1886) observaram que os nivels de resistencia a ramulose. apresentados por IInhagens obtidas dos cultivares CNPA-2H e BR-1 e das linhagens SU-0450-8008 C CNPA-81-200, foram slgniflcativamente malores do que aqueles apresentados pelas populaçZes orlginals. No flnal do tercelro clalo de seleção. o ganho genetico em resistencia variou de 21 a 61\%. sendo os malores nivels apresentados pelas duas linha gens orlgl nadas do cultivar BR-1.

Estudando a patogenicidade de dez 1 solados C. Bossypii var. cophalosporioides em relaçăo a tres 
cultivares e sete ilnhagens de algodoeiro, LIMA (1981) observou existir variabilidade entre os 1 solados testados. Esses resultados levaram o autor a concluir que é provável a existencia de raças do patógeno. No mesmo experimento sol observado năo haver relaçăo enure patogentclidade e os grupos de 1 solados. classificados quanto ao tipo e cor do micél10 aéreo, rorma da colónla e esporulaçăo. Apenas para duas culturas, pertencentes a dols grupos diferentes. roi observado que uma delas, de intensa esporulação, estava associada ao alto Indlce de tombamento. A outra. de batxa esporulação, estava relacionada com baixo indice de tombamento e superbrotamento. Observou-se correlação positiva entre a taxa de crescimento em melo de BDA e a patogenicidade des 1 solajos. Fol avaliada alnda. em casa de vegetaçăo a resistenc a de quatro linhagens de algodoeiro aos dez isolados do patogeno, observando-se diferenças no seu comportamento quanto a manifestaçáo de sintomas de ramul ose. Irés dessas 11 hhagens comportaram-se como resistentes e uma. como suscetivel. Os resultados deste trabalio permitiram tambem concluir que provavelmente uma planta resistente ao superbrotamento năo - necessariamente resistente ao tombamento e vice-versa. A seleça de plantas visando resistencia a ramulose em casa de vegetação, com o emprego de técnlcas padronizadas de inoculação, fol considerada pelo autor como mals adequada do que a seleção em condl ções de campo. 
CARVALHO et al11 (1885) investigaram, em 21 genótlpos de G. hirsutum var. Latifolium. com diferentes graus de pubescencia da folha, a influéncia da pilosidade na expressão de sintomas de ramulose. Verificaram que o nivel de resistencia esiava relacionado com o grau de pilosidade, sendo que os genótipos pilosos foram os mais suscetiveis e os de balica pilosidade, os mais resistentes.

CARVALHO et al11 (1888) evidenciaram que a resisténcia à ramulose e controlada por um par de genes. sendo a suscetibilidade parcialmente dominante. com grau de dominañcia 0.85 e herdabil1 dade 0.51 . No mesmo trabal ho os autores determinaram uma correlaçăo genética de 0.55 entre pilosidade e suscetibilidade a ramulose, isto o. as plantas glabras, via de regra, são resistentes e as pilosas suscetiveis. Portanto, a seleçăo de plantas para resistencia à ramulose podera ser felta. também. pela menor pllosidade na superficie da folha.

\footnotetext{
2.5. Resistência relactonada à transmissão de patógenos por sementes.
}

A ampla variabilidade genetica existente quanto a resistencia das plantas aos patógenos. presumi vel mente deve se estender ao nIvel de transmissão destes pelas sementes.

Alguns trabalhos realizados com algodoeiro 
- outras culturas. no entanto, evidenciaram que nem sempre existe essa correspondéncia.

Sob esse aspecto. DHINGRA \& KUSHALAPPA (1980). trabalhando com a mancha angular do seljoelro. verificaram que nào nouve correlação entre a intensidade da doença no campo e a incidencia de Isariopsis griseola nas sementes. Somente $1.85 \%$ das sementes originadas de vagens doentes transportavam o patogeno, correspondendo áquelas que estavam localizadas diretamente em contacto com leşres na sutura da vagem. Em todas essas sementes, 0 rungo se desenvol veu no local correspondente ao hilo.

Estudos realizados por LASCA et alii (1880), sobre a relaçăo entre ocorréncla de antracnose em cultura de felja e a lncidencia de colletotrichum indemuthionum em sementes, mostraram não ter havido correspondencia entre a quantidade de doença nas plantas e quantidade do patogeno nas sementes por elas produzldas. DHINGRA et al11 (1986) realizaram exper1mentos com feljoelro em duas localidades do estado de Minas Gerals. nas estaçôes chuvosas e não churosas, para determinar a relação entre incidencia de antracnose no campo e a produção de sementes transmissoras de $C$. inderuthianum. Os resultados mostraram que. embora a porcentagem de sementes que transmitem o patogeno dependa da Incidencia na parte aérea (folhas e vagens). este parametro nzo e um indlcador da proporção de sementes produzi- 
das portadoras do fungo. Os autores comentaram que pelo menos a proporçá de vagens doentes poderia estar relaciorada com a porcentagem de sementes com o patógeno. mas os dados demonstraram o contrário. Esses resultados estzo de acordio com aqueles obtidos por GOMES (1878), que embora tenha observado alta proporção de vagens doentes. verificou balxa incldencla nas sementes, não tendo sido observada correlaçăo entre a proporção de vagens com sintomas a porcentagem de sementes que transportaram $C$. Lirdemutrianum.

Em estudos realizados com gergelim CSesomun indicum, KUROZAWA et al11 (1985) analisaram 0 comportamento de 13 cultivares quanto a lncidoncla de Cercospora sesami em condlçoes de campo e sua presença na semente. Dols dos cultivares ut1lizados comportaram-se como resistentes e apresentaram balxa incldencla do fungo nas sementes. Os demals. comportaram-se como suscetivels, apresentando alta incldencla do patógeno nas sementes. A aisalise entre o comportamento dos cultivares quanto a doença a lncidéncia do fungo nas sementes mostrou uma correlaçăo positiva. Este fato demonstra a lmportancla de se utillzar cultivares mais resistentes, pols além de haver menores danos em campo, as sementes, em consequencia, estarão carregando menor quantidade de inoculo.

Irabalhando com ramulose do algodoeiro. 
PIZINATTO \& CIA (1887) estudaram a relação entre a incidencia de ramulose em plantas inoculadas no campo a a presença do patógeno nas sementes produzidas. Foram analisadas sementes de 11 cultivares, com diferentes mivels de resistencia, utilizando-se o neluvio do papel de Plitro, com sementes deslintadas e com linter. A porcentagem de deteção de colletotrichun fol sempre malor nas sementes deslintadas do que naquelas com linter. Verificou-se que nem sempre houve uma relaçăo entre a infeç̧a no campo e a presença do patógeno nas sementes.

$$
\text { PIZANATTO et al11 (1888) realizaram }
$$

estudos sobre a transmlssåo de c. gossypit var. cephalosporioides por sementes de algodoeiro e sua disseminação em campo, utilizando os cultivares EPAMIG-3 (testemunha resistente). IAC-12-2, IAC-19 e a I1nhagem Nu-15 (testemunha suscetivels. Os resultados permitiram observar que a porcentagem de incidancla da doença no campo e a porcentagem de transmissão pela semente foram menores para o cultivar EPAMIG-3 e malores para a linhagem Nu-15. No entanto.' nem todos os cultivares mostraram relaçáo entre severidade da doença e incidencia do patógeno na semente. Por outro lado, a porcentagem de sementes com o patógeno rol menor para o cultivar mals resistente, portem, não rol malor para a 1 inhagem Nu-15 Cmais suscetivel), e sim. para o cultivar IAC-12-2. 
3. MATERIAL E METODOS.

- presente trabalho rol realizado nos laboratórios e casa de vegetação do Departamento de Fitopatologia da Escola Superior de Agricultura "Luiz de Queiroz". da Universidade de STo Paulo, em Piracicaba, no perlodo compreendido entre marco de 1988 a revereiro de 1989.

3.1. Isolamento e preparo das suspensöes de conidios.

As culturas puras de Colletotrichum 8ossypii e C. gossypii var. cephalosporioides foram obtidas atraves de isolamentos em meio BDA Cbatata 200 g; dextrose $20 \mathrm{~g}$; agar $20 \mathrm{~g}$; água dest $1 \mathrm{lada} 1000 \mathrm{ml} \mathrm{l}$.

Quando os 1 solamentos foram feltos a partir de sementes, estas permaneceram 3 a 7 dias em cămara úmida. sendo as estruturas do fungo desenvolvidas na sua superficie transferidas para placas de Petri com BDA. através de uma agul ha Ilambada.

Os 1 solamentos de lesbes de rol has. maçăs. caules e plantulas foram reltos com pequenos fragmentos de 
tecidos, apos assepsia superficial em solução de hipoclorito de sod10 a $1 \%$ durante um minuto.

Os 1 solados dos dols patógenos ut1lizados. assim como sua procedencia e orgão da planta de onde foram obtidos, encontrañ- = Macionados na Tabela 1.

De cada isolado foram obtidas culturas monosporlcas, espalhando-se uma suspensăo dilulda de conidios sobre a superficle de agar-água em placas de Petri. Após aproxtmadamente 18 horas de incubação a $28^{\circ} \mathrm{C}$. as plạ cas foram observadas em microscopio. Os esporos Individua lizados foram transferidos com pequena quantldade de agar para novas placas contendo BDA, Incubadas a $28^{\circ} \mathrm{C}$.

Após a obtenção de culturas monospóricas. os 1 solados foram preservados em agua destilada ester1112ada, pelo método de Castellanl (FIGUEIREDO, 1987). Tal método consistiu na transferencia de discos $3 \mathrm{~mm}$ de diametro, retirados de colonias em crescimento ativo, para vidros com capacidade aproximada para $10 \mathrm{ml}$ (vidros de penicilina vazios. contendo $4 \mathrm{ml}$ de agua destilada esterilizada. Os vidros, após tampados com rolha de borracha - vedados com fllme transparente de PVC ("MAGIPACK"), roram mantidos sob temperatura de $10^{\circ} \mathrm{C}$ (geladeiras.

Para os experimentos de inoculação de sementes e plantas de algodoelro, as suspenszes de conidios foram obtidas adiclonando-se $10 \mathrm{ml}$ de agua destilada esterilizada a cada placa de Petri de $\theta$ cm de 
Tabela 1 - Relaç̧o dos 1 solados ut1l1zados. sua procedéncla e órgão da planta de onde foram obtidos.

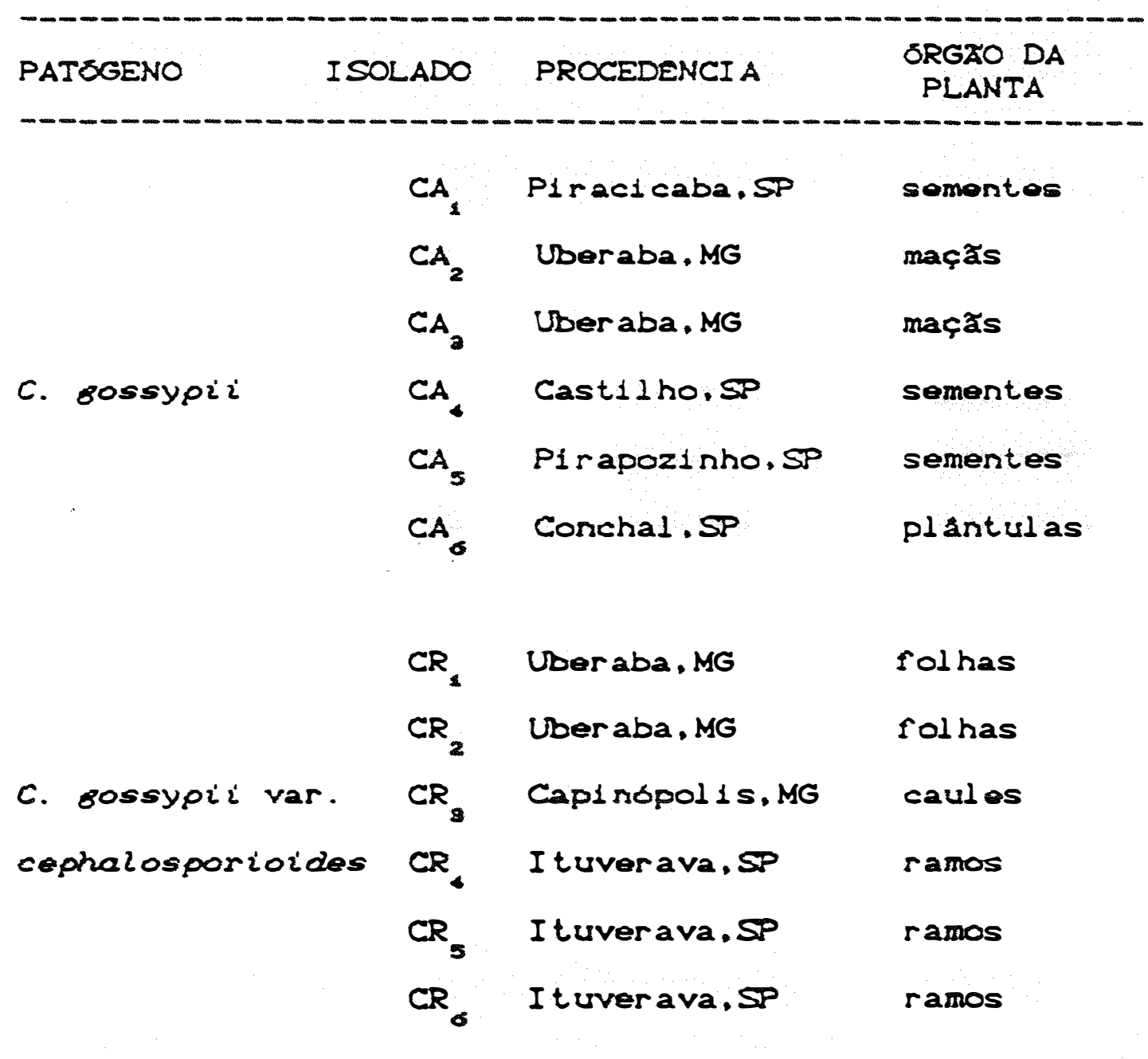


diametro contendo as culturas dos fungos desenvolvidos durante 8 dias à temperatura ambiente $\left(25-28^{\circ} \mathrm{C}\right.$, em melo de avela Cfartinha de avela 40 g; agar 20 g; água destilada $1000 \mathrm{ml}$. Um pincel fino rol passado sobre a superficie das colonias a I im ds factilitar a liberação dos conldios. Essas suspensరes foram flltradas atraves de duas camadas de gaze esterillzada e suas concentraç̧es ajustadas para $1 \times 10^{5}$ conldios $/ \mathrm{ml}$, atraves de contagens em hemocitometro e diluiçres com água dest1lada ester 111 zada.

3.2. Crescimento micelial e esporulação in vitro de C. gossypii var. cepralosporioides e C. sossypii.

\subsubsection{Crescimento micellal.}

Foram utilizadas culturas puras de $c$. gossypii e C. Bossypii var. cephalosporioides com 7 dias de 1dade, desenvol vidas em melo BDA a $28^{\circ} \mathrm{C}$. Com o auxil10 de um furador de rolhas foram retirados discos de $5 \mathrm{~mm}$ de diametro da parte periferica dessas culturas, que roram transferidos para o centro de placas de Petri de $\theta \mathrm{cm}$ de diametro, contendo BDA.

As placas assim preparadas foram mantidas a $28^{\circ} \mathrm{C}$. no escuro. Após 38 horas, a cada período de 10 e 14 horas, durante 96 horas, e ao rinal de 144 horas, fol medido o crescimento 11near, atraves de dols diametros das 
colónias, perpendiculares entre si, com o auxilio de uma rógua millmetrada.

O delineamento utilizado fol o intelramente ao acaso, com 3 repetiçzes por tratamento. A comparação de mélias fal reelizalia peio teste de Tukey.

\section{z. 2. 2. Esporulação.}

As placas foram praparadas de maneira semelhante a descrita no Item 3.2.1. ut1lizando neste caso os melos BDA e de aveia.

Após 6 dilas de 1 ncubação a $25^{\circ} \mathrm{C}$, no escuro. fol avaliada a esporulação, retirando-se de cada placa 3 discos de $1.5 \mathrm{~cm}$ de diametro. amostrando o centro e as duas extremidades do ralo das placas razendo-se a suspensão dos esporos em $10 \mathrm{ml}$ de água destilada. Após filtraçăo em camada dupla de gaze. a contagem do numero de conidios rol realizada mediante o emprego de hemocitómetro.

o dell neamento experimental ut1l1zado para cada patógeno fol o intelramente ao acaso, em esquema fato rial a (melos) $\times 6$ (isolados) com 3 repetif̧res, cada uma constituida por uma placa.

Os dados obtidos foram submetidos a analise de variancia. utilizando-se o teste de Tukey para a comparação das médias. 
3.3. Patogenicidade de sels isolados de C. 8ossypii var. cepralosporioides em plantas de nove genótipos de algodoeiro.

Neste experimento Iil avaidada a patogenicidade de sels isolados de C. 8ossypit var. cephalosporioides em nove genotipos de algodoelro, atraves da pulverização de suspensăo do 1 nóculo em plantas, em casa de vegetação.

Os 1 solados utilizados, relacionados na Tabela 1. foram inoculados individualmente em cada um dos genot1pos : BR-1, CNPA-2H, IAC-12-2, IAC-17. IAC-19, IAC20. I APAR-4-PR-1. EPAMI G-3 e Nu-15-79/117. As plantas foram cultivadas em vasos de alumbio de $15 \mathrm{~cm}$ de diametro, contendo cerca de $1.5 \mathrm{~kg}$ de uma mistura esterilizada em autoclave de.solo, areia e materia organica, respectivamente nas proporços de $2: 1: 1$ em volume.

O delineamento estatist1co ut111zado rol o inteiramente ao acaso. com 3 repetiçes por tratamento. cada uma delas constitus da por um vaso contendo 3 plantas. o esquema experimental sol o ratorial 6 (1solados) $x \theta$ (genotipos).

A Inoculação consistiu da pulverizaçzo de uma suspensão de esporos, preparada de acordo com o 1 tem 3.1. quando as plantas tinham 30 dias de 1dade. A pulverizaçao rol realizada ao slinal da tarde, através de 
um pulverizador manual "UNI-SPRAY" modelo 2000, procurando-se atingir principalmente a parte apical da planta.

Após a inoculação as plantas permaneceram om camara úmlda. proporclonada por uma cobortura plástica. por 48 horas, para garantir a umidade adequada para ocorrer a infecção.

como testemunha. 3 vasos, contendo 3 plantas de cada genotipo, foram pulverizados com agua destilada ester 111 zada.

A avaliação sol efetuada 25 dias após a inocul ação, determi nando-se a severidade da doença em cada planta por sintomas visuais, atraves da atribulçăo de notas de 1 a 5. conforme escala utilizada por CARVALHO et al11 (1985). doscrita a seguir:

$$
\begin{aligned}
& \text { Nota } 1 \text { - Ausencia de sintomas. } \\
& \text { Nota } 2 \text { - Aponas leszos nocrotleas nas } \\
& \text { rol has. } \\
& \text { Nota } 3 \text { - Plantas com Intornddios euperioros } \\
& \text { Nota - Suporbrotamonto acontuado; roduça } \\
& \text { do porte da planta. } \\
& \text { Nota } 5 \text { - Exccoesivo euporbrotamonto; porto } \\
& \text { reducldo, de maneira mals } \\
& \text { acontuada do quo no caso } \\
& \text { anterior. }
\end{aligned}
$$

A partir dessa escala de notas rol calculado o Indice de doença (IDS. pela fómula sugerida por MCKINNEY (1823): 


$$
\begin{aligned}
& \text { ID } C: D=\frac{\sum(r \cdot v)}{n \cdot x} \cdot 100 \text {, onde: } \\
& I D=1 \text { ndice de doença } \\
& f=\text { numero de plantas com determinada nota } \\
& v=\text { nota observada } \\
& n=\text { inmero toral de plantas avaliadas } \\
& x=\text { nota maxima }
\end{aligned}
$$

- Os dados obtidos. transformados para

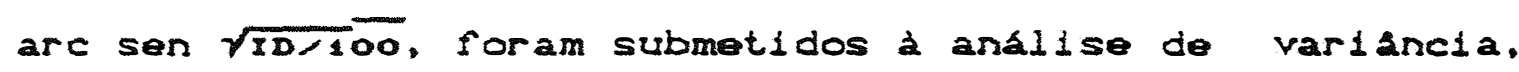
ut11izando-se o teste de Tukey para a comparaçao das médias.

As temperaturas minima. maxima e média observadas na casa de vegetaçăo durante o periodo em que soi realizado o experimento foram de 14,39 e $28,7^{\circ} \mathrm{C}$. respect1 vamente.

3. 4. Transmissão de C. sossypii var. cepholosporioides pelas sementes de cinco genótipos de algodoeiro Inoculados em dols estadios de desenvolvimento.

o experimento fol conduzido em casa de vegetaçăo. em delineamento inteiramente ao acaso. em esquema ratorial 5 (genótipos) $\times 2$ (estádios de desenvol vimentos. com cinco repetiços por tratamento. Cada repeticá rol constitulda por um vaso de plastico de $23 \mathrm{~cm}$ de diámetro - capacidade aproximada de $4.5 \mathrm{~kg}$. contendo o substrato mencionado no 1 tem 3.3. Em cada vaso foram cultivadas 
tress plantas.

Foram utilizados os cultivares IAC-ZO, IAC-12-2, IAPAR-4-PR-1, EPAMI G-3 (padrão de resistencia) e a I1nhagem Nu-15-78/117 (padrăo de suscetibil1dade).

Fes preparado o inóculo, com culturas puras dos 8 isolados do fungo relacionados na Tabela 1 , com 8 dias de idade, desenvolvidas em meio de avela. Foram preparadas suspenszes de esporos de cada 1solado. na concentração de $1 \times 10^{5}$ esporos $/ \mathrm{ml}$, mediante a tecnica ja descrita no ltem 3.1. Volumes 1guals de cada suspensão foram misturados, de modo a se obter a mistura de 1solados.

As plantas foram inoculadas atraves de pulverizador manual "UNI-SPRAY" mod. 2000, em dols estadlos de cresclmento : aos 30 dlas após a semeadura (plantas jovens) e quando a maloria das maçass estava formada. As pulverizaçzes foram realizadas ao final da tarde, procurando-se atingir principalmente a parte apical das plantas.

Após as inoculaçôes as plantas permaneceram em cámara úmida, proporclonada por uma cobertura plástica. por 48 horas.

Como testemunha. 5 vasos contendo 3 plantas de cada genótipo foram pulverizadas com agua destilada ester111zada.

As avaliaçós da severtidade da doença nas 
plantas foram efetuadas 30 dias após as inoculaçres. mediante a escala de notas de 1 a 5 , adotada por CARVALHO et al11 (1985). com as quals foram calculados os Indices de doença. de modo semelhante ao descrito no 1 tem 3.3.

As temperaturas minima. maxima a úcía observadas na casa de vegetaçăo durante a condução do exper 1 mento foram, respectivamente, 05, 39 e $22.1^{\circ} \mathrm{C}$.

As plantas desenvol veram-se ate a rase de maturidade, sendo as sementes colhidas e submetidas aos testes relacionados a seguir:

3.4.1. Anallise de sandiade das sementes.

As sementes colhidas foram previamente deslintadas com ácido sulfúrico comercial concentrado c96-98\%. na proporção de $200 \mathrm{ml}$ para cada $1 \mathrm{~kg}$ de sementes. As sementes em contato com o acido foram revolvidas com um bastăo de vidro durante cerca de 5 minutos e a seguir lavadas várias vezes em agua corrente e postas a secar a sombra CCOSTA \& SANTOS NETO, 1940.

A presença do patógeno fol detectada através do teste de sanldade ut1l1zando incubaçăo em papel de filtro (NEERGAARD, 1070 s. O método consistiu na incubaçz̃o das sementes em placas de Petri de plástico, de $0 \mathrm{~cm}$ de diametro, contendo 3 folhas de papel de filtro umedecidas com agua destilada. As placas. contendo cada uma 10 
sementes equidistantes entre si. foram colocadas durante 7 dias a $20-22^{\circ} \mathrm{C}$. fotoperiodo de 12 horas de escuro o 12 horas de luz, forneclda por duas lampadas GE 40 watts, UNIV F $40 \mathrm{SD}$ (super luz do dia), distantes $25 \mathrm{~cm}$ uma da outra a $40 \mathrm{~cm}$ das placas.

0 delineamento estatistico fol 0 inteiramente ao acaso, com 4 repetiçZes de 50 sementes por tratamento. O esquema experimental fol o ratorial 5 cgenotipos) $\times 2$ (estádios de desenvol vimento).

A avaliação foi efetuada observando-se a presença de estruturas do rungo sobre as sementes e plantulas, com 0 auxil10 de um estereomicroscóplo.

A analise de variancia fol efetuada com os dados, em porcentagem. transformados para are sen $\sqrt{\times / 100}$. ut1l1zando-se o teste de Tukey para a comparaçăo das medias.

3.4.2. Transmissão do patógeno semente-plântuia.

Para verificar a transmissão do patógeno para as plantulas, as sementes, deslintadas com ácldo sulftrico, de acordo com o item 3.4.1.. foram semeadas em calleas plasticas de $45 \times 30 \times 11 \mathrm{~cm}$, contendo o substrato menclonado no 1tem 3.3., em casa de vegetaçăo. En cada calsea foram distribuidas 25 sementes.

- delineamento estatistico rol o 
inteiramente casualizado. em esquema ratorial 5 cgenótpos) $x \geq$ (estádios de desenvolvimentos com 4 repetiç̧es por tratamento, cada uma delas constituida por 2 calxas (50 sementes). Como testemunha foram utilizadas sementes obtidas de plantas não lnucivacias.

Na avaliaçăo, realizada 14 dias apos a semeadura. foram contadas as plantulas sobreviventes. Todas as plantulas foram retiradas do substrato e examinadas quanto a presença de lesర̌es no colo, haste e rol has. calculando-se a porcentagem de plantulas sobreviventes com sintomas.

A porcentagem de redução da emerguncia referente a cada tratamento fol calculada pelo confronto da sua emergencia com a da respectiva testemunha. ut1l1zando-se a formula:

$$
\begin{aligned}
& P R E=\frac{E I-E I r}{E I} \cdot 100, \text { onde: } \\
& P R E=\text { porcentagem de redução da emergencia } \\
& E I=\text { emergencia da testemunha } \\
& \text { EIr = emergencia do tratamento }
\end{aligned}
$$

Relacionando-se os dados obtidos para porcentagem de plantulas sobreviventes com sintomas e porcentagem de sementes com o patógeno. fol calculada a porcentagem de transmissão semente-plantula:

Os dados obtidos foram transformados para arc sen $\sqrt{x / 100}$ e submetidos a analise de variancia. sendo as modias comparadas pelo teste de Tukey. 
3.5. Comparação de mítodos de inoculação de sementes de algodoeiro com C. gossypil var. cepralosporioides e C. gossypit.

Fü äi utllizadas sementes do cultlvar CNPA-2H, deslintadas com ácido sulfúr1co, conforme o item 3.4.1.. e submetidas a assepsia superficlal com hipociorito de sodilo a $1 \%$ durante 3 minutos, seguida de secagem ao ar. em papel absorvente, durante 24 horas.

Os seis isolados de $C$. gossypit e $C$. gossypi var. cephalosporioides relacionados na Tabela 1 foram ut111zados como inoculo.

3.5.1. MEtodos utillzados.

3.5.1.1 Motodo 1 - Contacto das sementes com colônias dos fungos durante 24 horas e secagem por 24 horas.

Como inoculo foram utilizadas culturas dos dois patógenos desenvol vidas em placas de Petri de $9 \mathrm{~cm}$ de diametro, com BDA, durante 8 a 10 dlas, em condlçăo amblente de laboratório, com a temperatura variando entre 25 a $28^{\circ} \mathrm{C}$. Em cada placa foram colocadas 50 sementes em contacto com a superficie das colonias, num procedimento semelhante ao descrito por IANAKA et al11 (1887). As 
placas foram agitadas manualmente para que as sementes entrassem em contacte com as colonias. permitindo maior àdesåo do inóculo a sua superficio. A incubaçăo foi realizada em condiçres de laboratório, durante 24 horas. Como testemunia as sementes permaneceram em contacto com a superflcie de BDA em placas de Petri durante 24 horas.

Após a inoculaçåo $\theta$ antes de serem utilizadas, as sementes foram postas a secar ao ar $\theta$ a sombra,durante 24 horas, sobre papel absorvente.

\subsubsection{Mbtodo 2 - Imorsão das sementes em suspensão de conidios durante 30 minutos e secagem por duas horas.}

As sementes foram imersas em uma suspensao de esporos do rungo, na concentraça de $1 \times 10^{3}$ esporos/ml, obtida da maneira descrita no Item 3.1, durante 30 minutos. Para cada 100 sementes foram utilizados $100 \mathrm{mlda}$ suspensão. Como testemunha, a sementes foran imersas em água destilada esterilizada durante 30 minutos.

Após a inoculaçăo, antes de serem utilizadas, as sementes foram postas a secar ao ar $\theta$ à sombra, durante 2 horas, sobre papel absorvente. 
3.5.1.3. Metodo 3 - Imersão das sementes em suspensão de conidios durante 2 horas e secagem por 16 horas.

As sementes foram imersoc distanie duas horas em uma suspensăo de esporos na concentraçăo de $1 \times 10^{5}$ esporos/ml. preparada conforme o Item 3.1. colocando-se 100 sementes para cada $100 \mathrm{ml}$ da suspensão. A segulr foram postas a secar ao ar e à sombra. sobre papel absorvente. durante 16 horas. Para a testemunha a suspensão de esporos fol substituida por água destilada esterilizada.

Artes e após a inocul açăo com cada método. uma amostra das sementes fol destinada à determinaçăo do grau de umidade pelo metodo da estufa a $105^{\circ} \mathrm{C}$ CMARCOS FILHO et ali1. 1987J. Foi também determinado o grau de umidade das sementes só deslintadas e deslintadas com assepsia. Procedeu-se a nova determinaçăo do grau de umidade das sementes inoculadas, após um mós de armazenamento em sacos de papel, a temperatura ambiente.

Os danos provocados pela presença dos patógenos em sementes a plantulas for am avallados atraves dos testes menclonados a seguir.

3.5.2. Anhilse de sanidade das sementes.

A avallação rol felta pelo teste de sani- 
dade. incubaça em papel de riltro. cuja tecnica rol descrita no 1tem 3.4.1. Foram analisadas 200 sementes por tratamento. sendo metade dinas submetidas a assepsia superficial com soluçăo de hipoclorito de sodio a $1 \%$ durante 3 minutos.

Fol utilizado o delineamento estatistico Inteiramente ao acaso. com 5 repetiçres de 20 sementes por tratamento. constituldas por $a$ placas de 9 cm de diámetro. cada uma delas contendo 10 sementes.

A analise de variancia fol efetuada com os dados, em porcentagem, transformados para arc sen $\sqrt{\times 100}$. utilizando-se o teste de Tukey para a comparaçao das medias.

3.5.3. Emergência em casa de vegetação.

As sementes foram semeadas om caixas plasticas de $45 \times 30 \times 11 \mathrm{~cm}$. contendo o substrato mencionado no 1 tem 3.3. em número de 25 por caixa.

o delineamento estatistico fol o inteiramente ao acaso. com 4 repetiçós de 50 sementes por tratamento. cada uma constitulda por 2 calxas.

Na avaliaçzo. roalizada 14 dias apos a semeadura. foram consideradas a emergencla a as plantulas sobreviventes com sintomas, de modo semelhante ao descrito para o Item 3.4.2. 
A analise de variancia roi efetuada com os dados transformados para arc sen $\sqrt{x / 100}$, uti11zando-se 0 teste de Tukey para a comparaçăo das médias.

As temperaturas minima. maxima e média

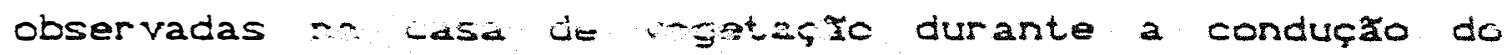
experimento foram 15,38 e $26,4^{\circ} \mathrm{C}$, respectivamente.

3.6. Patogenicidade de C. eossypi var.cephalosporioides - C. gossypiz a cinco genótipos de algodoeiro, atraves de inoculação de sementes.

Utilizando os genotipos IAC-12-2. IAC-ZO. IAPAR-4-PR-1. EPANI G-3 (padrão de resistencia a ramulose) e Nu-15-79/117 (padrão de suscetibilidade a ramuloses e os isolados de c. gossypii e c. gossypii var. cephalosporioides, relacionados na Tabela 1 , foi reita a inoculação das sementes pelo método 3. descrito no 1 tem 3.5.1.3.

- inóculo foi preparado de acordo com a técnica especificada no 1 tem 3.1. sendo preparada uma suspensão de esporos de cada isolado. na concentraçao de $1 \times 10^{5}$ esporos/m. Para cada patogeno, volumes iguals do cada suspensão for am misturados para a obtençăo da mistura de isolados. da qual foram utilizados $100 \mathrm{ml}$ para 100 sementes.

Foram inoculadas 400 sementes de cada 
genótipo. sendo metade delas utilizada para anallse om laboratorto a a outra metade. para verificar a emergóncia e sintomas em plantulas, em casa de vegetaçăo.

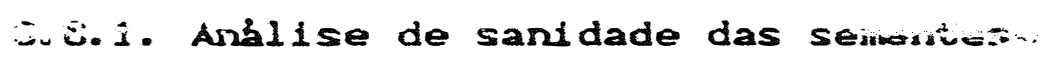

Em laboratório a patogenicidade rol avaliada pelo teste de sanidade. incubaçăo em papel de filtro. cuja descriçăo e modo de avaliação constam no 1 tem 3.4.1.

- delineamento experimental fol o inteiramente ao acaso, com 5 repetiçzes de 20 sementes para cada tratamento. constituldas por duas placas. com 10 sementes cada.

A analise de variancia foi realizada com os dados em porcentagem transformados para are sen $\sqrt{\times / 100}$. sendo as médias comparadas pelo teste de Tukey.

3.6.2. Emergência en casa de vegetação.

As sementes foram distribuidas em caixas plásticas de $45 \times 30 \times 11 \mathrm{~cm}$ contendo o substrato mencionado no 1 tem 3.3. Foram utilizadas 25 sementes em cada caixa. em delineamento experimental inteiramente casualizado. com 4 repetiçres, cada uma delas constituida por duas calxas.

As avaliaçzes e a analise de variancia foram realizadas de modo semelhante 20 deserito para 0 
Item 3.4.2.

As temperaturas máxima. minima e média observadas na casa de vegetaça durante a conduça do experimento foram. respectivamente. 13.38 e $25.6^{\circ} \mathrm{C}$. 


\section{$\therefore$ RESULTADOS}

No Apondice encontram-se os valores da diferenças minimas signiflcativas CDMSO, Utilizadas nas comparaç̧es de médlas.

As tabelas 6 a 23 referem-se a dados reais. tendo sido as comparaçóes das médlas realizadas após transfor mação.

4.1. Crescimento micelial e esporulacão in vitro de $C$. gossypii var. cephalosporioides e C. Bossypii.

\subsubsection{Crescimento micelial.}

Os resultados obtidos para o crescimento 11 near de $C$. gossypii var. cephalosporioides encontram-se na Tabel a 2 .

A analise de variancia mostrou serem signiricativas as diferenças entre o crescimento linear dos 1 solados utilizados. O 1 solado $C R$ apresentou malor cresclmento em relação aos demals após 144 horas de 1 ncubação. porém năo diferiu estatisticamente de $C R_{1}$ e $C R_{2}$ Os 1501 ados $C R_{5}$ e $C R_{6}$ foram os que cresceram menos durante o mesmo 
Tabela 2 - Crescimento rabsial de seis isolados de C. sossypil var. cephelosporioides en BDA.

\begin{tabular}{|c|c|c|c|c|c|c|c|c|}
\hline \multirow{2}{*}{ ISOLADOS } & \multicolumn{3}{|c|}{ HORAS } & DE & \multicolumn{2}{|c|}{ I NCUBACุÃO } & & \\
\hline & 38 & 48 & 62 & 72 & 86 & 86 & $144^{\circ}$ & \\
\hline & 1.83 & 2.48 & 3.30 & 3.86 & 4.73 & 5.42 & 8.43 & $\mathbf{a}$ \\
\hline$C R_{1}$ & 1.80 & 2.00 & 3.25 & 3.80 & 4.86 & 5.40 & 8.37 & $a b$ \\
\hline$C_{2}$ & 1.70 & 2.10 & 3.23 & 3.58 & 4,54 & 5.33 & 8,33 & $a b$ \\
\hline$C R$ & 1.73 & 2.23 & 3.13 & 3.86 & 4.50 & 5.26 & 8.08 & be \\
\hline$C R$ & 1.46 & 1.86 & 2.96 & 3.43 & 4.36 & 5.10 & 8.00 & $c$ \\
\hline $\mathrm{CR}_{\widehat{\sigma}}$ & 1.40 & 1.80 & 2.73 & 3.20 & 4.07 & 4.73 & 7.80 & $c$ \\
\hline
\end{tabular}

- Medras obtidas apos 144 horas de incubaçao.seguldas pela mesma letra. não diferiram entre si ao nivel de 5\% de probabil1dade pelo teste de Tukey. 
perído. năo diferindo estatisticamente de CR.

Para o crescimento de $C$. gossypiz a analise de variancia também mostrou diferenças significativas CTabela 3. Os 1 solados $\mathrm{CA}_{1} \cdot \mathrm{CA}_{+} \mathrm{CA}_{3}$ aprosentaram crescimentos estatisticamente semeinantes, diferindo dos demais. O isolado $C A_{\sigma}$ rol o que menos cresceu durante as 144 horas de incubaçăo. porém năo diferilu estatisticamente do isolado $\mathrm{CA}_{2}$, que por sua vez não diferiu de CA,

4. 1.2. Esporulação.

is dados obtidos quanto a esporvlaçăo dos dols patogencs em estudo. nos meios BDA e aveila encontram-se nas Tabelas 4 e 5.

Atraves da análise de variancia foram observadas diferencas significativas entre os malos de cultura. entre lsolados e para a lnteraçăo melos $x$ 1solados. tanto para C: sossypil como para C: gossypii var. cephalosporioides.

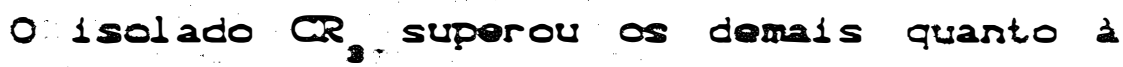
esporulação. sendo seguldo por $\mathrm{CR}_{5}$. do qual não diferiv estatisticamente. 0 1solado $C R$ apresentor a mals baitea esporulação. sicasdo $C_{1}$ i $C_{2}$ e $C_{0}$ em posição intermediar 1 a.

Para todos os 1 solados a esporulação em melo de avela fol superior aquela observada en BDA. Aponas para $C_{4} a$ dferença entre as esporulaçes obtıdas nos 
Tabela 3 - Crescimento micelial de seis isolados de C. gossypiz em BDA.

\begin{tabular}{|c|c|c|c|c|c|c|c|c|}
\hline \multirow{2}{*}{ ISOLADOS } & \multicolumn{3}{|c|}{ HORAS } & \multicolumn{3}{|c|}{ INCUBACÃO } & & \\
\hline & 38 & 48 & 62 & 72 & 86 & 96 & 144 & \\
\hline & -- & & - & $e m--$ & & $-\frac{-1}{2}$ & --- & -- \\
\hline$C A_{1}$ & 1.53 & 2.17 & 3.47 & 4.23 & 5.40 & 5.96 & 8.30 & $\mathbf{a}$ \\
\hline $\mathrm{CA}_{4}$ & 1.43 & 1.97 & 2.90 & 3.57 & 4.47 & 5.26 & 8.23 & $\mathbf{a}$ \\
\hline $\mathrm{CA}_{3}$ & 1.53 & 1.80 & 2.80 & 3.43 & 4.37 & 5.03 & 8.16 & a \\
\hline $\mathrm{CA}_{5}$ & 1.36 & 1.90 & 2.83 & 3.50 & 4.63 & 5.27 & 7.83 & $b$ \\
\hline $\mathrm{CA}_{2}$ & 1.43 & 2.07 & 3.17 & 3,57 & 4.33 & 5.27 & 7.66 & bc \\
\hline $\mathrm{CA}_{6}$ & 1.26 & 1.83 & 2.83 & 3.40 & 4.23 & 5.20 & 7.47 & c \\
\hline
\end{tabular}

- Medias obtidas após 144 horas de incubaçăo.seguidas pela mesma letra. não diferiram entre si ao nivel de 5\% de probabilidade pelo teste de Tukey. 
Tabela 4 - Esporulaçăo de seis isolados de C. gossypii var. cepralosporioides nos melos BDA e aveia.

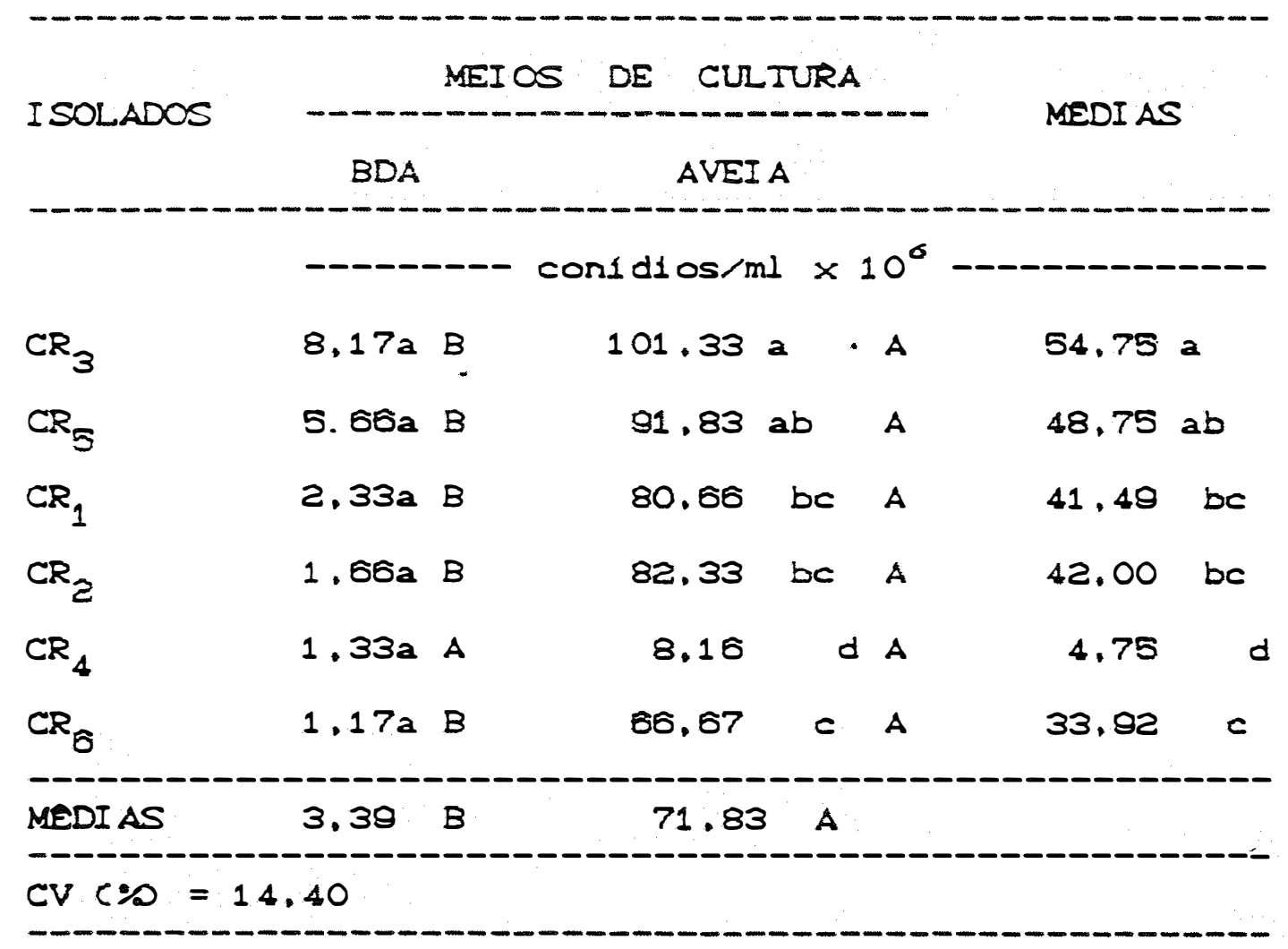

Letras minúsculas comparam medias na vertical e malúsculas na horizontal.

Medias seguidas pela mesma letra não diferem entre si ao nivel de 5\% de probabilidade pelo teste de Tukey. 
Tabela 5 - Esporulação de seis isolados de C. Bossypii nos meios BDA e areia.

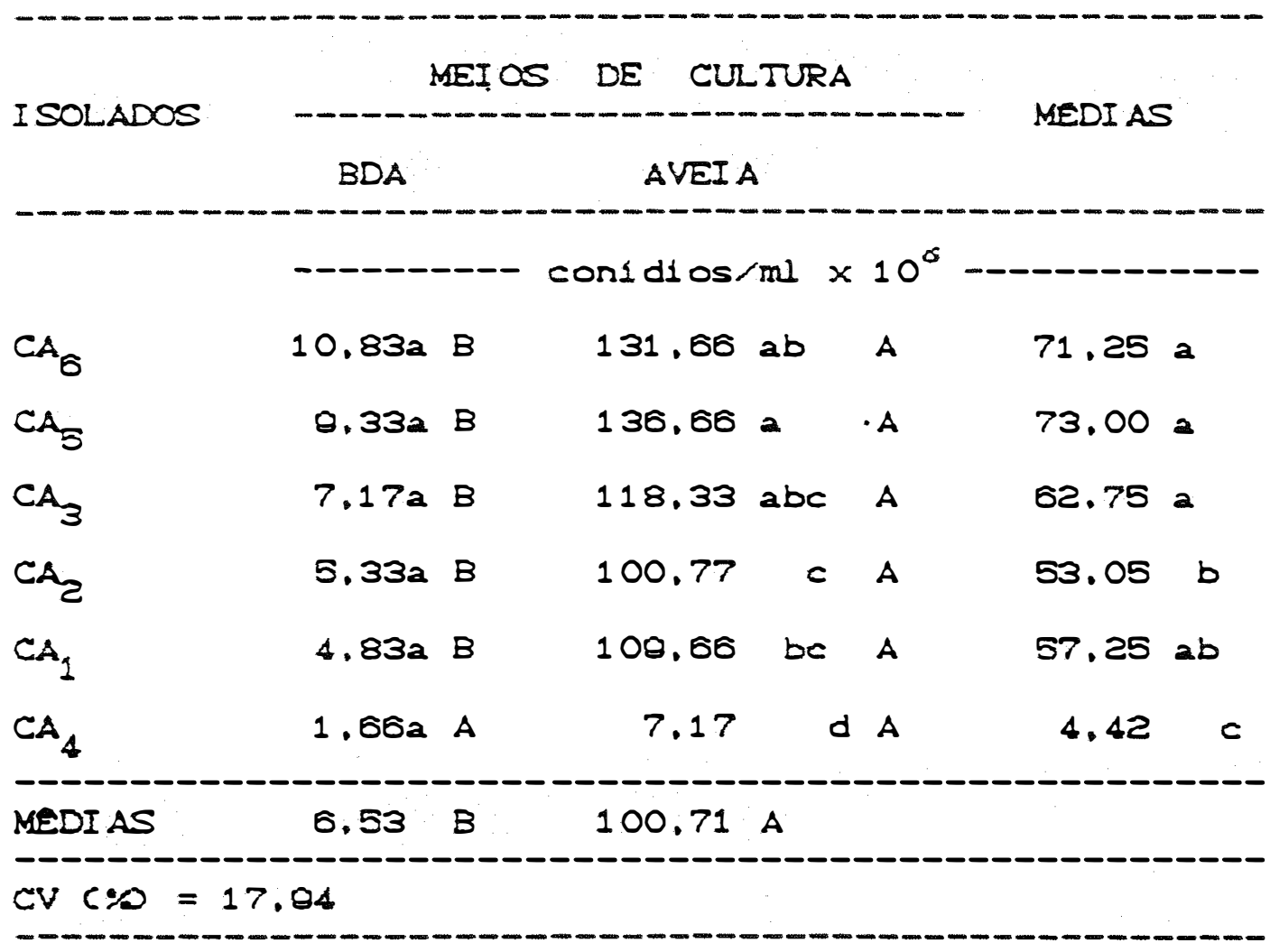

Letras mlnúsculas comparam medias na vertical e malúsculas na horizontal.

Médias seguidas pela mesma letra não diferem entre si ao nivel de $5 \%$ de probabilidade pelo teste de Tukey. 
dols melos năo roi signiricativa.

No desdobramento dos graus de liberdade da interação melos $x$ isolados de c. gossypii var. cephalosporioides, a analise de variancia revelou

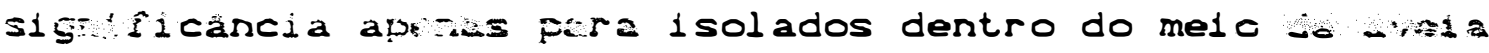
(Tabela 4). Neste meio. os isolados diferiram entre si de modo semelhante ao observado para a média geral.

Também para C. Eossypiz (Tabela 5). a análise de variancia para o desdobramento dos graus de 11 berdade da interação melos $x$ isolados mostrou haver significancia apenas para lsolados dentro do melo de avela, no qual se sobressalram os 1 solados $C A_{5}, C A_{6}$ e $C A_{9}$. Náo rol acusada siginificancia para os melos dentro de CA . $^{\circ}$ Na media geral, os isolados $C A_{1}, C A_{3}, C A_{5}$ e $C A_{6}$ nao diferiram estatisticamente entre $\mathbf{s}$, sendo no entanto, superiores ao CA, e $\mathrm{CA}_{2}$.

No estudo de correlação entre crescimento e esporulação foram obtidos os coeficientes de 0.37 e 0.48. năo significativos ao nivel de 5\% de probabilidade pelo teste $t$. respect1vamente para os 1 solados de $C$. gossypii yar. cephalosporioides e C. Bossypii.

4. 2. Patogenicidade de seis isolados de C. bossypii var. cepraiosporioides em plantas de nove genbtipos de al godoeiro. 
se manifestar tres a quatro dias apos a inoculaçao. na forma de pequenas leşes necroticas no $11 \mathrm{mbo}$ foliar. nerviras. e ao longo dos peciolos. com posterior necrose da parte apical. cuja intensidade variou com a suscet:Li11dide do genotipo.

As plantas testemunhas mantiveram-se sem sintomas da doença.

Na Tabela 6 săo apresentados os resultados das reaçరes exibidas pelos genotipos de algodoelro aos isolados de C. sossypit var. cephalosporioides.

A analise de variancia mostrou diferenças significativas para genotipos, 1 solados e para a interação genótipos $\times$ isolados.

No desdobramento dos graus de liberdade da interação genótipos x lsolados, a analise de variancia mostrou exitirem diferenças significativas para isolados dentro de genótipos. com exceção de 1 solados dentro do cultivar EPAMIG-3 (Tabela 6). Tambem foram observadas diferenças estatisticamente significativas para genótipos dentro de isolados. com exceção de genótipos dentro do isolado CR

Na Tabela 6 observa-se que os 1 solados $C_{3}$ e $C_{5}$ destacaram-se como os mals patogenicos. Estes dols isolados foram estatisticamente iguais quanto a patogenicidade e diferiram dos 1 solados $C R_{1}, C R_{2}$ e CR $6^{\prime}$ com patogenicidade intermediaria. que. por sua vez. diferiram de CR . o menos patogenico. 


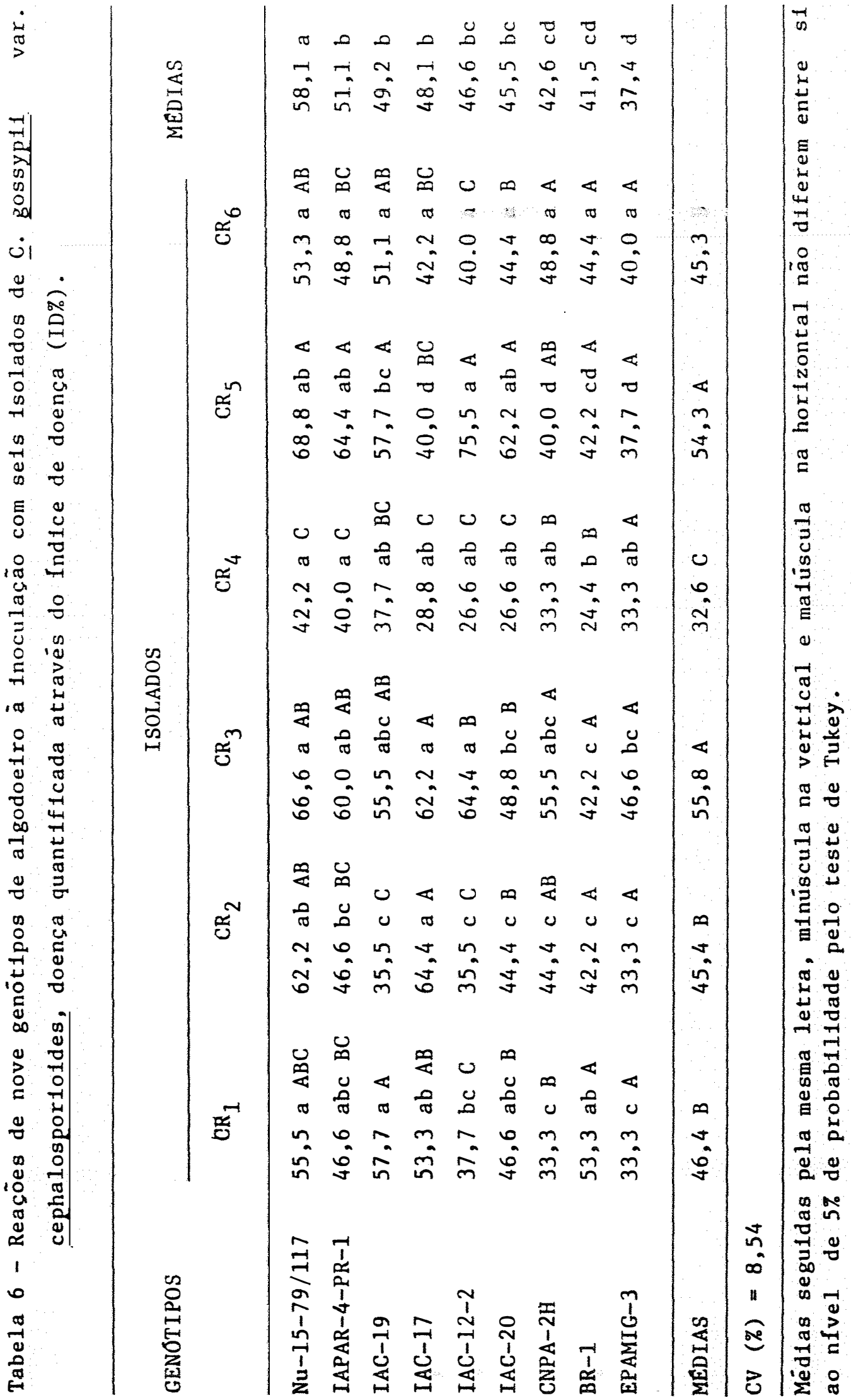


Os nove genótipos de algodoeiro apresentaram diferentes nlveis de reaç̧es quanto a sintomatologia resultante da inoculação com cada um dos seis isolados. conforme pode-se observar na Tabela E. A Iinhagem

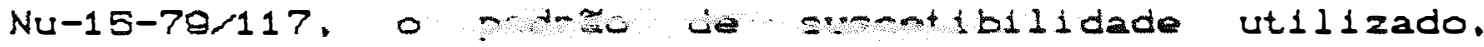
apresentou o mais alto Indice de doença em médla. sendo significativamente diferente dos demais. Os Indices de doença apresentados por esta linhagem em relação a todos os isolados. apenas foram superados pelos dos genotipos IAC-19. IAC-17 e IAC-12-2 frente aOs 1 solados $C R_{1}, C R_{2} e$ $C R_{5}$, respectivamente. Por outro lado, o cultivar EPAMIG-3 comportou-se como o genótipo mais resistente, com o menor Indice de doença em média. Seguiram-se em ordem crescente de suscetibilidade os cultivares BR-1. CNPA-2H. IAC-2O, IAC-12-2. IAC-17. IAC-1 8 e I APAR-4-PR-1.

4. 3. Transmussão de C. gossypii var. cephalosporioides pelas sementes de cinco genbtipos de algodoeiro Inoculados en dois estadios de desenvolvimento.

Decorridos tres a quatro dias após a inoculaçăo foram observados os primeiros sintomas da doença. na forma de pequenas manchas necroticas no 11 mbo Soliar e lesbes alongadas nas nervuras e peciolos. Essas leszes, com o tempo. provocaram enrugamento. deformaçzes ou queda das rolhas, e em progressao a parte apical fol atingida. com evoluçăo para o superbrotamento em malor ou 
menor grau. dependendo da suscetibilidade do genótipo.

$$
\text { As plantas testemunhas mantiveram-se sem }
$$

sintomas da doença.

Na Tabela 7 encontram-se os dados referent s a incice- to doença apresentados pelos ánco genótipos testados quando 1 noculados com uma mistura dos seis isolados de C. gossypii var. cephalosporioides, em dois estádios de desenvol vimento.

A analise de variancia mostrou serem significativas as diferenças observadas entre genótipos. épocas de inoculaçăo, e para a interação genótipos $x$ épocas.

A Iinhagem Nu-15-78/117 e o cultivar IAPAR-4-PR-1 foram os genotipos que apresentaram os mais altos indices de doença em média, não diferindo estatisticamente entre si. porém diferindo dos cultivares com Indice intermediario. IAC-12-2 e IAC-20. Estes, por sua vez, năo diferiram entre si. diferindo no entanto do cultivar EPAMIG-3, o mais resistente.

Os Indices de doença resultantes da inoculação realizada quando a maioria das maçăs estava formada foram. em media. estatisticamente inferiores aqueles obtidos quando a inoculaçăo fol efetuada 30 dias após a semeadura.

No desdobramento dos graus de liberdade da interação genótipos $x$ épocas. a analise de variancia mostrou. dentro de cada época de inoculação. os mesmos 
Tabela 7 - Indices de doença resultantes da inoculaçăo de mistura de seis isolados de C. Bossypiz var. cephalosporioicies em cinco genótlpos it algodoeiro, em dols estádi t- de desonumi. vimento.

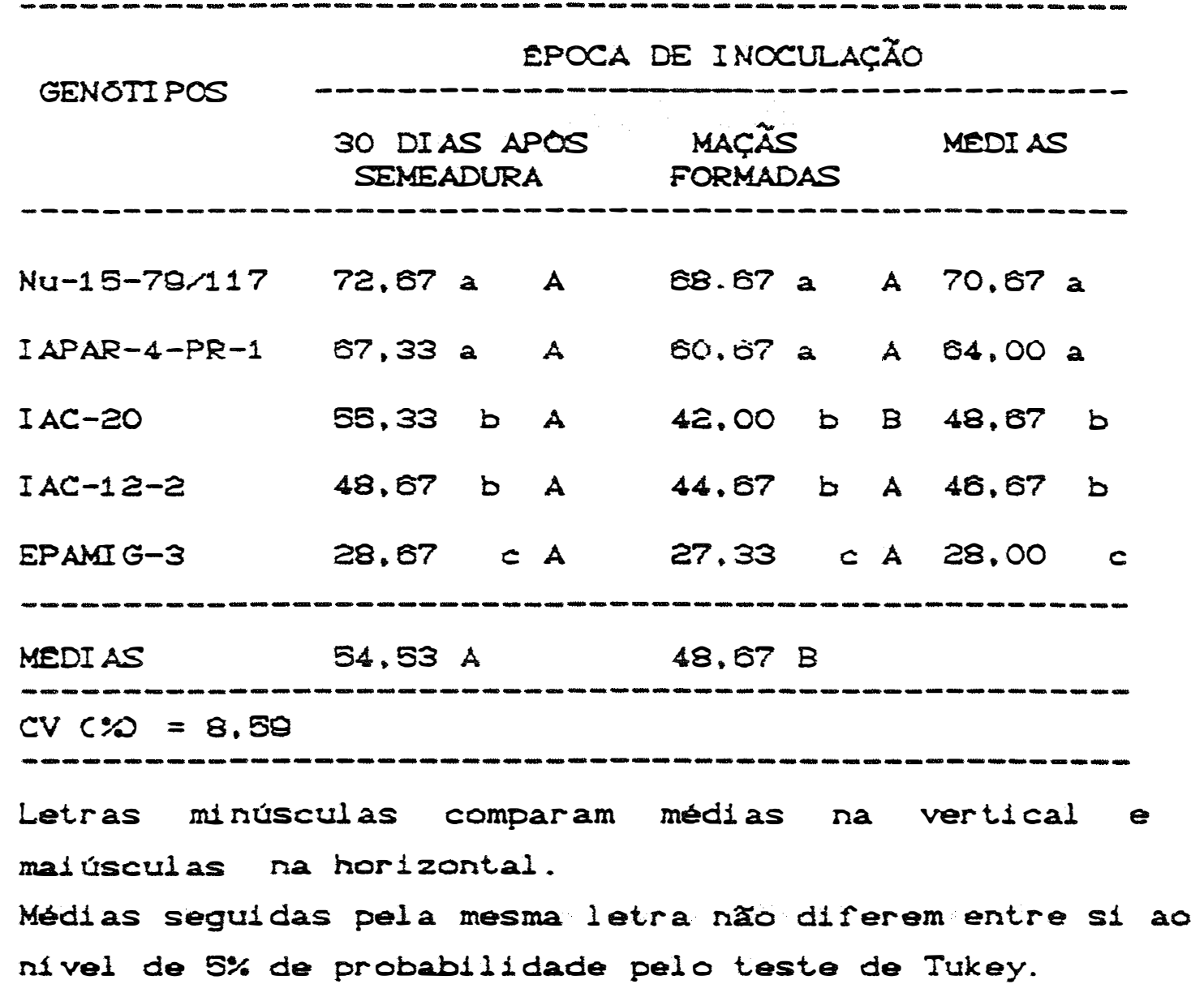


resultados constatados para as medias dos genotipos. A Inhagem Nu-15-79/117 e o cultivar IAPAR-4-PR-1 comportaram-se como os mais suscetiveis. IAC-20 e IAC-1Z-2, como intermediarios e EPAMI $5-3$, como 0 mais - pototente. Apenas para o culti $\cdots$ IAC-EO How diferença significativa entre os indices de doença observados para as duas épocas de inoculaçăo.

4.3.1. Analise de sanidade das sementes.

As porcentagens de sementes com $C$. gossypit var.cepralosporioides, provententes das plantas inoculadas 30 dias apos a semeadura e quando a maioria das maçãs estava formada, encontram-se na Tabela 8.

Atraves da analise de variancia foram observadas diferenças significativas entre genótipos. épocas de inoculação e para a interaçăo genótipos x épocas. As sementes dos cultivares IAC-12-2 e EPAMIG-3 apresentaram, em media, a maior o menor porcentagem do fungo. respectivamente.

Quando a inoculaçăo fol efetuada no estádio em que a maioria das maçăs estava formada. foram detectadas nas sementes porcentagens de C. Bossypii var. cephalosporioides, signiflcativamente superiores aos valores observados quando se 1 nocul ou aos 30 dias (Tabela 8). $\mathrm{Na}$ interação genotipos $x$ epocas do inoculação observa-se que as sementes do cultivar IAC-1Z-Z 
Tabela 8 - Porcentagens de sementes com C. gossypii var. cephalosporioides provenientes das plantas inoculadas em dois estádios de desenvolvimento Ctransilssao pianizanmertel.

\begin{tabular}{|c|c|c|c|c|c|}
\hline \multirow[b]{2}{*}{ GENOTI POS } & \multicolumn{5}{|c|}{ EPOCA DE INOCULAÇÃO } \\
\hline & $\begin{array}{l}30 \text { DI AS } \\
\text { SEMEADU }\end{array}$ & $\begin{array}{l}\text { APOS } \\
\text { RA }\end{array}$ & $\begin{array}{l}\text { MAÇÃS } \\
\text { FORMADAS }\end{array}$ & & MEDIAS \\
\hline I $A C-12-2$ & $5.00 \mathrm{a}$ & B & $11.50 \mathrm{a}$ & $A$ & $8.25 \mathrm{a}$ \\
\hline I AC-20 & $3,50 a b$ & B & $8.00 \mathrm{ab}$ & $\mathbf{A}$ & $5.75 \mathrm{a}$ \\
\hline$N u-15-78 / 117$ & $3,00 \mathrm{abc}$ & $B$ & $5.50 \quad b$ & $A$ & $4.25 \mathrm{a}$ \\
\hline I APAR-4-PR-1 & $1.50 \mathrm{bc}$ & B & $10.00 \mathrm{ab}$ & $\mathbf{A}$ & $5.75 \mathrm{a}$ \\
\hline EPAMI G-3 & $1.00 c$ & $A$ & $1.50 \mathrm{c}$ & A & 1.25 \\
\hline MEDI AS & $2.80 \mathrm{~B}$ & & $7.30 \mathrm{~A}$ & & \\
\hline$C V C \%=24$. & & & & & \\
\hline
\end{tabular}

Letras mí núscul as comparam

medias na vertical e malúsculas na horizontal.

Medias seguidas pela mesma letra não diferem entre si ao nivel de $5 \%$ de probabilidade pelo teste de Tukey. 
e EPAMI G-3 apresentaram malores e menores porcentagens do patogeno em ambas as epocas de 1 noculaçăo. respectivamente (Tabela 8).

O dasdobramento dos graus do libordado da interação jeribipus $x$ focas mostrou que apenas para cultivar EPAMIG-3 nåo houve diferença significativa entre as porcentagens de sementes portadoras do patogeno nas duas épocas testadas.

4. 3.2. Transmissão do patógeno semente-plântula.

Na Tabela $\theta$ são apresentadas as porcentagens de redução da emergencia das sementes originadas das plantas inoculadas nos dols estadios de desenvol vimento.

A analise de variancia mostrou serem significativas as diferenças entre genotipos. epocas de inoculação e a interação genótipos x epocas.

A malor porcentagem de redução da emergéncia. em média. fol verificada para o cultivar IAC-12-2. que diferiu significativamente dos demais genótipos. A menor redução da emerguncia fol verificada para o cultivar EPAMIG-3. Ficando os demais genotipos em posição intermediária.

- valor médio de redução da porcentagem de emergencia quando da inoculação aos 30 dias rol estatisticamente inferior lquele obtido para o estadio de 
Tabela 8 - Porcentagens de reduçăo da emergéncia do sementes provenientes de plantas 1 noculadas com C. Bossypii var. cephalosporioides em dois - túdios de desenvolvimento.

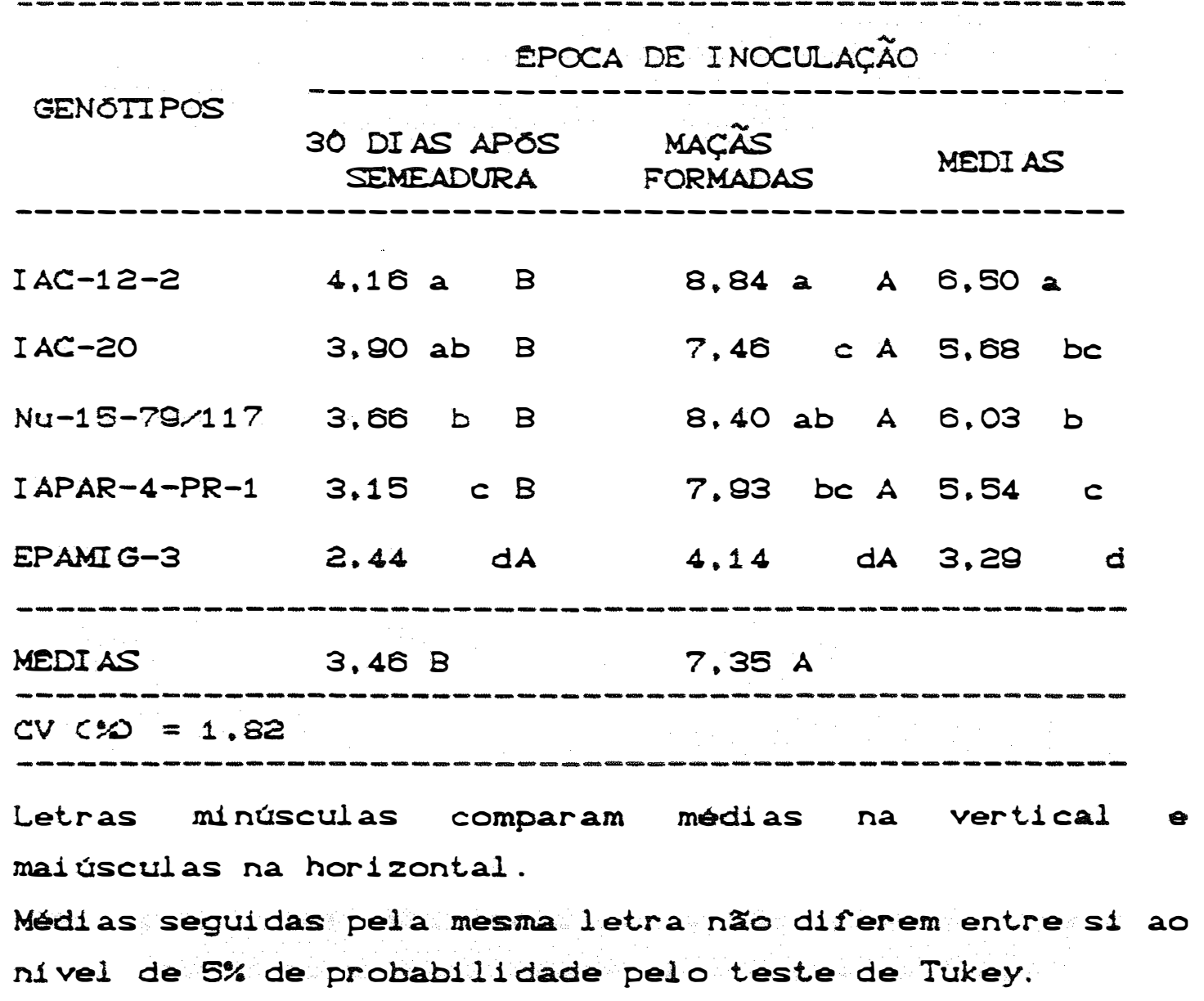


maçăs formadas (Tabela 9 ).

$\mathrm{Na}$ interação genótipos $x$ epocas. na inoculaçăo aos 30 dias, o cultivar IAC-12-2 apresentou a malor reduçăo da emergencia. não diferindo

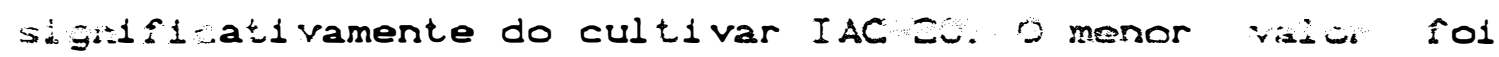
observado para o cultivar EPAMIG-3. Quando a 1 noculaçăo rol efetuada com maçăs formadas. houve altaração nesta sequéncia. Neste caso. o cultivar IAC-12-2 apresentou malor redução da emergéncia, porém năo diferiu significativamente de Nu-15-79/117. O cultivar EPANG-3 manteve-se com o mals balxo valor. flcando como interme. diarios os cultivares IAPAR-4-PR-1 e IAC-2O (Tabela 9).

Os cultivares IAC-12-Z e EPAMIG-3 apresentaram a malor e menor reduçao da emergencia dentro de ambas as épocas, respectivamente. A emergencia de todos os genotipos fol significativamente menor quando a inoculaçao fol efetuada no estádio de maçãs formadas (Tabela g).

Os dados referentes à porcentagens de plantulas sobreviventes com sintomas. provenientes das sementes das plantas inoculadas podem ser vistos na Tabela 10.

A analise de variancia mostrou existir ereito significativo para genótipos. épocas de inoculação a interação genótipos $\times$ épocas.

Os cultivares IAC-12-2 e EPAMIG-3 apresentaram. em média. malor e menor porcentagem de plantulas sobreviventes com sintomas. respectivamente, diferindo 
Tabela 10 - Porcentagens de plantulas sobreviventes com sintomas. provenientes das sementes de plantas inoculadas com C. gossypii var.

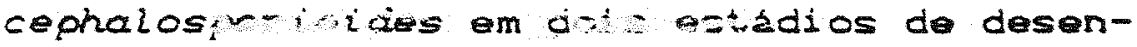
vol vi mento (Transmissăo semente-plantula).

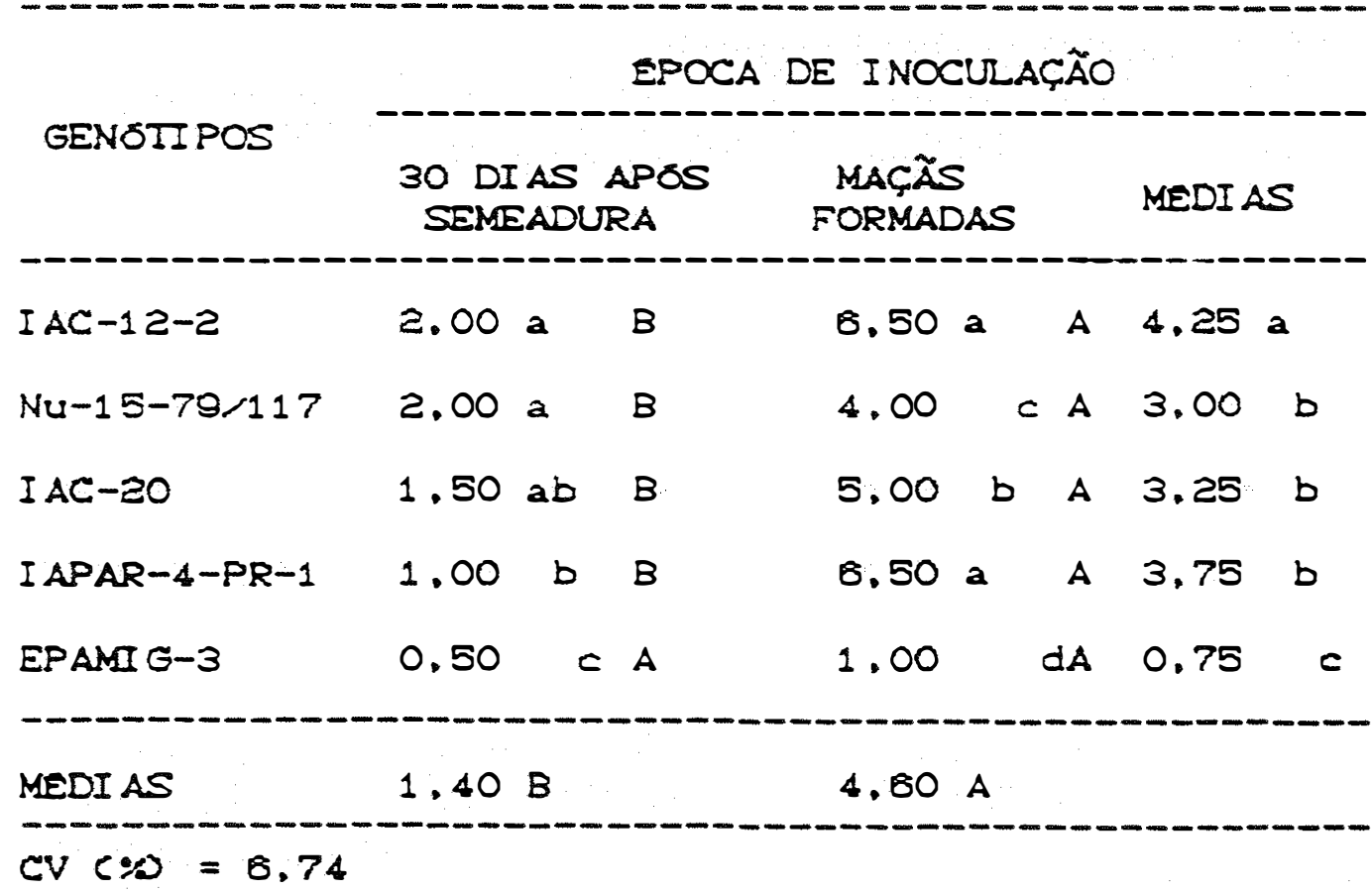

Letras minúsculas comparam médias na vertical e malúsculas na horizontal.

Médias seguidas pela mesma letra năo diferem entre si ao nivel de 5\% de probabilidade pelo teste de Tukey. 
significativamente dos demais cultivares.

Comparando os valores médios obtidos para as duas epocas de inoculaçăo, observou=se que eles foram significativamente diferentes entre si. com a inoculaçăo

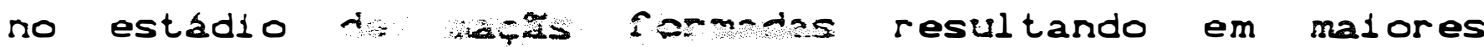
porcentagens de plantulas com sintomas.

A interação genotipos $x$ épocas mostrou que em ambas as épocas o cultivar EPAMIG-3 apresentou a menor porcentagem de plantulas com sintomas. (Tabela 10 .

Com os resultados das Tabelas 8 e 10 foram calculadas as porcentagens medlas de transmissão do patógeno pelas sementes, cujos resultados săo apresentados na Tabela 11

Os genotipos Nu-15-78/117 e EPAMIG-3 apresentaram a malor e menor porcentagem de transmissão semente-plantula, respectivamente.

4.4. Comparação de mśtodos de inoculação de sementes com C. gossypiz var. cephalosporioides e $c$. gossypiz.

4. 4.1. Análise de sanidade das sementes.

Os resultados obtidos para incidoncia de cada isolado de C. gossypii var. cephalosporioides nas sementes inoculadas com os métodos 1 , 2 e 3 . encontram-se nas Tabelas 12. 13 e 14. respectivamente. 
Tabela 11 - Porcentagens medias de transmissão de C. gossypil var. cefralosporioides pelas sementes de cinco genótipos de algodoeiro. c-j-- plantas-mãe foram inoculadas am anis estadios de desenvolvimento. em casa de vegetação.

\begin{tabular}{|c|c|c|c|}
\hline \multirow[b]{2}{*}{ GENOTIPOS } & \multicolumn{3}{|c|}{ EPOCA DE INOCURAÇÃO } \\
\hline & $\begin{array}{l}30 \text { DI AS APOS } \\
\text { SEMEADURA }\end{array}$ & $\begin{array}{c}\text { MAÇÃS } \\
\text { FORMADAS }\end{array}$ & MEDI AS \\
\hline $\mathrm{Nu}-15-79 / 117$ & 67 & 73 & 70 \\
\hline I APAR-4-PR-1 & 67 & 65 & 66 \\
\hline EPAMI G-3 & 50 & 67 & 58 \\
\hline I AC-2O & 43 & 63 & 53 \\
\hline I $A C-12-2$ & 40 & 57 & 48 \\
\hline MEDI AS & 53 & 65 & \\
\hline
\end{tabular}

Teste F năo signiflcativo ao nivel de 5\% de probabi11 dade. 
Tabela 12 - Porsentagens de sementes do cultivar CNPA2H com C. gossypit var. cephalosporioides, resultantes da inoculaçåo com o mátujo 1 contacto das sementes an cultuas t- furgo durante 24 horas e secagem durante 24 horas.

\begin{tabular}{|c|c|c|c|c|}
\hline ISOLADOS & $\begin{array}{c}\text { SEM } \\
\text { ASSEPSI A }\end{array}$ & $\begin{array}{c}\text { COM } \\
\text { ASSEPSI A }\end{array}$ & MEDI AS & \\
\hline${ }_{5}^{C R}$ & 98.00 & 83.00 & 90.50 & $\mathbf{a}$ \\
\hline$C R_{3}$ & 98.00 & 80.00 & 89.00 & $\mathbf{a}$ \\
\hline$C R_{1}$ & 96.00 & 74.00 & 85.00 & $a b$ \\
\hline $\mathrm{CR}_{2}$ & 95.00 & 70,00 & 82.50 & $a b c$ \\
\hline$C R_{6}$ & 84.00 & 65.00 & 74.50 & bc \\
\hline$C R_{4}$ & 80.00 & 81.00 & 70.50 & $c$ \\
\hline MEDIAS & $91.80 \mathrm{~A}$ & $72.20 \mathrm{~B}$ & & \\
\hline
\end{tabular}

Letras minúsculas comparam médias na vertical e mal úsculas na horizontal.

Medias soguidas pola mesma lotra nao diforom ontro sil ao nivel de 5\% de probabilidade pelo teste de Tukey. 
Tabela 13 - Porcentagens de sementes do cultivar CNPA2H com C. Bossypiz var cephalosporioides resultantes da 1 noculação com o método 2 imersão das wrentes na silponsã de inocu10 durante $30 \mathrm{minutos}$ e secagem por 2 horas.

\begin{tabular}{|c|c|c|c|}
\hline I SOLADOS & $\begin{array}{c}\text { SEM } \\
\text { ASSEPSI A }\end{array}$ & $\begin{array}{l}\text { COM } \\
\text { ASSEPSI A }\end{array}$ & MEDI AS \\
\hline$C_{3}^{C R}$ & 78.00 & 23.00 & 51.00 \\
\hline$C R_{5}$ & 75.00 & 20,00 & 47.50 \\
\hline$C R_{1}$ & 72.00 & 18,00 & 45,00 \\
\hline$C R_{2}$ & $6 \theta .00$ & 15.00 & 42.00 \\
\hline$C R_{\sigma}$ & 58.00 & 18.00 & 38,00 \\
\hline$C R_{4}$ & 55.00 & 14,00 & 34.50 \\
\hline MEDI AS & $88.00 \mathrm{~A}$ & $18.00 \mathrm{~B}$ & \\
\hline
\end{tabular}

Letras minúsculas comparam medias na vertical e malúsculas na horizontal.

Medias seguidas pela mesma letra nao diferem entre si ao mesmo nivel de 5\% pelo teste de Iukey. 
Tabela 14 - Porcentagens de sementes do cultivar CNPAZH com C. gossypii var. cephalosporioides resultantes da 1 nocul ação com o metodo 3 i...ersăo das senerites na suspensão de esporos durante 2 horas seguida de secagem por 16 horas.

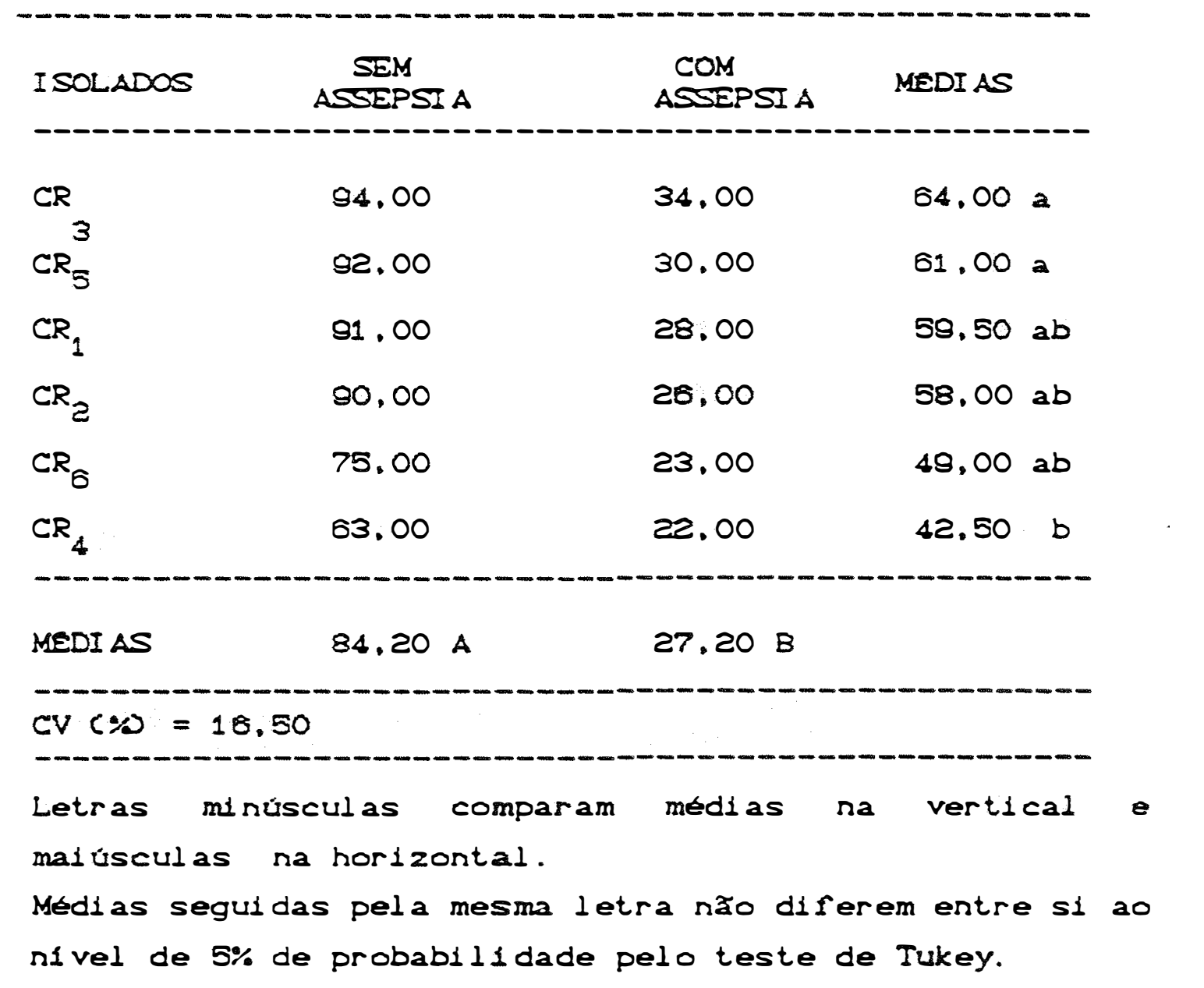


Para todos os métodos testados a analise de variancia mostrou serem significativas as diferenças entre isolados e assepsia. porém năo para a interaçăo isolados $x$ assepsia.

Conpar anóu us 1 sol ados em cada método. pode-se observar que no método 1 (Tabela 12 ). destacaram-se como mais jatogenicos $C R_{5}$ e $C R_{9}$. que năo diferiram significativamente de $C R_{1}$ e $C R_{2}$. 0 isolado $C R$. comportou-se como o menos patogénico.

Na tabela 13, verifica-se que pelo método 2 os isolados $C R_{3}$ e $C R_{4}$ destacaram-se como o mais e o menos patogénico, respecti...mente. ficando os demais em posiçao intermediária.

No método 3 (Tabela 14), destacaram-se como mais patogénicos $C R_{3}$ e $C R_{5}$ e como menos patogénico $C R_{4}$. de modo semelhante ao método 1 .

As porcentagens de incidencia do patogeno foram significativamente superiores nas sementes năo submetidas à assepsia. sendo o método 1 o mals eficiente na ootençăo de sementes infectadas. seguindo-se o método 3 CTabela 153

Nas Tabelas 16. 17 e 18 encontram-se os resultados referentes as porcentagens de sementes com $C$. gossypii. resultantes da 1 noculaçăo com os métodos 1 . 2 e 3. respecti vamente.

A analise de variancia mostrou existirem diferenças significativas apenas para presença ou ausencia 
Tabela 15 - Porcentagens de sementes do cultivar CNPAZH com C. gossypii var. ceprolosporioides, Inoculadas com 3 diferentes mátodos. com ou sem assepsia superricial.

\begin{tabular}{|c|c|c|c|}
\hline METODOS & $\begin{array}{c}\text { SEM } \\
\text { ASSEPSI A }\end{array}$ & $\begin{array}{l}\text { COM } \\
\text { ASSEPSIA }\end{array}$ & MEDI AS \\
\hline 1 & $81.80 \mathrm{a} A$ & 72.20 a B & $82.00 \mathrm{a}$ \\
\hline 3 & $84.20 \mathrm{~b} A$ & 27.20 b $B$ & $55.70 b$ \\
\hline 2 & $68.00 \subset A$ & $18.00 \subset B$ & $43.00 \mathrm{c}$ \\
\hline MEDI AS & $81.33 \quad A$ & 39.13 & \\
\hline
\end{tabular}

Letras minúsculas comparam medias na vertical e malúsculas na horizontal.

Médlas seguidas pela mesma letra não diferem entre si ao nivel de 5\% de probabilidade pelo teste de Tukey. 
Tabela 16 - Porcentagens de sementes do cultivar CNPAZH com C. gossypii. resultantes da inoculaça com o método 1 - contacto das samentes com culturas Lu fingo drimaive 24 horas e secagem durante 24 horas.

\begin{tabular}{|c|c|c|c|}
\hline ISOLADOS & $\begin{array}{c}\text { SEM } \\
\text { ASSEPSI A }\end{array}$ & $\begin{array}{l}\text { COM } \\
\text { ASSEPSI A }\end{array}$ & MEDI AS \\
\hline${ }_{5}$ & 97.00 & 76.00 & 86.50 \\
\hline $\mathrm{CA}_{1}$ & 84.00 & 79.00 & 86.50 \\
\hline $\mathrm{CA}_{4}$ & 84,00 & 79.00 & 86.50 \\
\hline $\mathrm{CA}_{3}$ & 93.00 & 84.00 & 88.50 \\
\hline $\mathrm{CA}_{2}$ & 90.00 & 73.00 & 81.50 \\
\hline $\mathrm{CA}_{6}$ & 80.00 & 75.00 & 82.50 \\
\hline MEDI AS & $93,00 \mathrm{~A}$ & $77.70 \mathrm{~B}$ & \\
\hline
\end{tabular}

Medlas seguldas pela mesma letra nao diferem entre sl ao nivel de $5 \%$ de probabilidade pelo teste de Tukey. 
Tabela 17 - Porcentagens de semente do cultivar CNPA-2H com C. gossypii. resultantes da inoculaçăo com o método 2 - imersão das sementes na susf-..silo de inc...- durante 30 minutos e secagem duas horas.

\begin{tabular}{|c|c|c|c|}
\hline ISOLADOS & $\begin{array}{c}\text { SEM } \\
\text { ASSEPSI A }\end{array}$ & $\begin{array}{c}\text { COM } \\
\text { ASSEPSI A }\end{array}$ & MEDI AS \\
\hline $\mathrm{CA}_{4}$ & 81.00 & 19.00 & 50.00 \\
\hline $\mathrm{CA}_{1}$ & 80.00 & 21.00 & 50.50 \\
\hline $\mathrm{CA}_{2}$ & 79.00 & 14.00 & 46.50 \\
\hline$C A_{5}$ & 78.00 & 10.00 & 43,00 \\
\hline $\mathrm{CA}_{3}$ & 73.00 & 18.00 & 44.50 \\
\hline $\mathrm{CA}_{6}$ & 72.00 & 14.00 & 43,00 \\
\hline MEDI AS & $78.80 \mathrm{~A}$ & $15.70 \mathrm{~B}$ & \\
\hline
\end{tabular}

Medias seguidas pela mesma letra năo diferem entre si ao nlvel de $5 \%$ de probablilidade pelo teste de Tukey. 
Tabela 18 - Porcentagens de sementes do cultivar CNPA2H com C. sossypii, resultantes da inocula̧̧ăo com o método 3 - 1 mersão das sementes na susp-risau de inóculo durante duas horas segulda de secagem 16 horas.

\begin{tabular}{|c|c|c|c|}
\hline I SOLADOS & $\begin{array}{c}\text { SEM } \\
\text { ASSEPSI A }\end{array}$ & $\begin{array}{c}\text { COM } \\
\text { ASSEPSI A }\end{array}$ & MEDI AS \\
\hline CA & 94.00 & 30.00 & 62.00 \\
\hline $\mathrm{CA}_{4}$ & 92,00 & 41.00 & 66.50 \\
\hline$C A_{1}$ & 80,00 & 36,00 & 63.00 \\
\hline $\mathrm{CA}_{3}$ & 89.00 & 33,00 & 61.00 \\
\hline $\mathrm{CA}_{6}$ & 89.00 & 28.00 & 58.50 \\
\hline $\mathrm{CA}_{2}$ & 84,00 & 44,00 & 64.00 \\
\hline MEDIAS & $89.70 \mathrm{~A}$ & $35.30 \mathrm{~B}$ & \\
\hline
\end{tabular}

Medlas seguldas pela mesma letra năo diferem entro si ao nivel de $5 \%$ de probablildade pelo teste de Tukey. 
de assepsia. Para todos os métodos testados. os valores me dios mostraram que a assepsia resultou em menores porcentagens de incidéncia do fungo, significativamente diferentes daqueles observados para sementes sem assepsia.

Ia Tabela 19 veriflca-se, de nudo semelhante ao observado para C. sossypii var. cephalosporioides, a superioridade do método 1 na obtenção de sementes infectadas.

Os graus de umidade apresentados pelas sementes inoculadas com C. Bossypii var. cephalosporioides roram de 13.0 .11 .7 e $15.0 \%$ para os métodos 1.2 e 3 , respectivamente. $E$ as sementes so deslintadas e deslintadas com assepsia estavam com unidade de 8.0 e 8.1\%, respectivamente. Após um mes de armazenamento a temperatura ambiente em sacos de papel. os graus de umidade das sementes inoculadas pelos métodos 1,2 e 3 foram. respectivamente, $8,0,7,8$ e $11.2 \%$

\section{4.2. Emergência em casa de vegetação.}

Na Tabela 20 encontram-se os resultados obtidos para porcentagem de plantulas sobrevivantes com sintomas e redução da porcentagem de emergencia. resultantes da inoculação de sementes com C. gossypii var. cephalosporioides, por tros diferentes mótodos.

A analise de variancia mostrou serem significativas as diferenças entre os isolados comparados 
Tísala 19 - Porcentagens de sementes do cultivar CNPA$2 H$ com C. Bossypi: inoculadas com 3 diferentes métodos, com ou sem assepsia superricial.

\begin{tabular}{|c|c|c|c|}
\hline METODOS & $\begin{array}{c}\text { SEM } \\
\text { ASEPSI A }\end{array}$ & $\begin{array}{c}\text { COM } \\
\text { ASSEPSIA }\end{array}$ & MEDI AS \\
\hline 1 & 93.00 a $\mathrm{A}$ & 77.70 a $B$ & $85.35 \mathrm{a}$ \\
\hline 3 & 88.70 a $A$ & $35,30 b \mathrm{~B}$ & $62.50 \mathrm{~b}$ \\
\hline 2 & $76.80 \mathrm{~b} \mathrm{~A}$ & $15.70 \mathrm{C} B$ & $46.25 c$ \\
\hline MEDI AS & $86.50 \quad A$ & $42,80 \mathrm{~B}$ & \\
\hline
\end{tabular}

Letras minúsculas comparam médias na vertical e maiúsculas na horizontal.

Medias seguidas pela mesma letra não diferem entre si ao nivel de 5\% de probabilidade pelo teste de Tukey. 


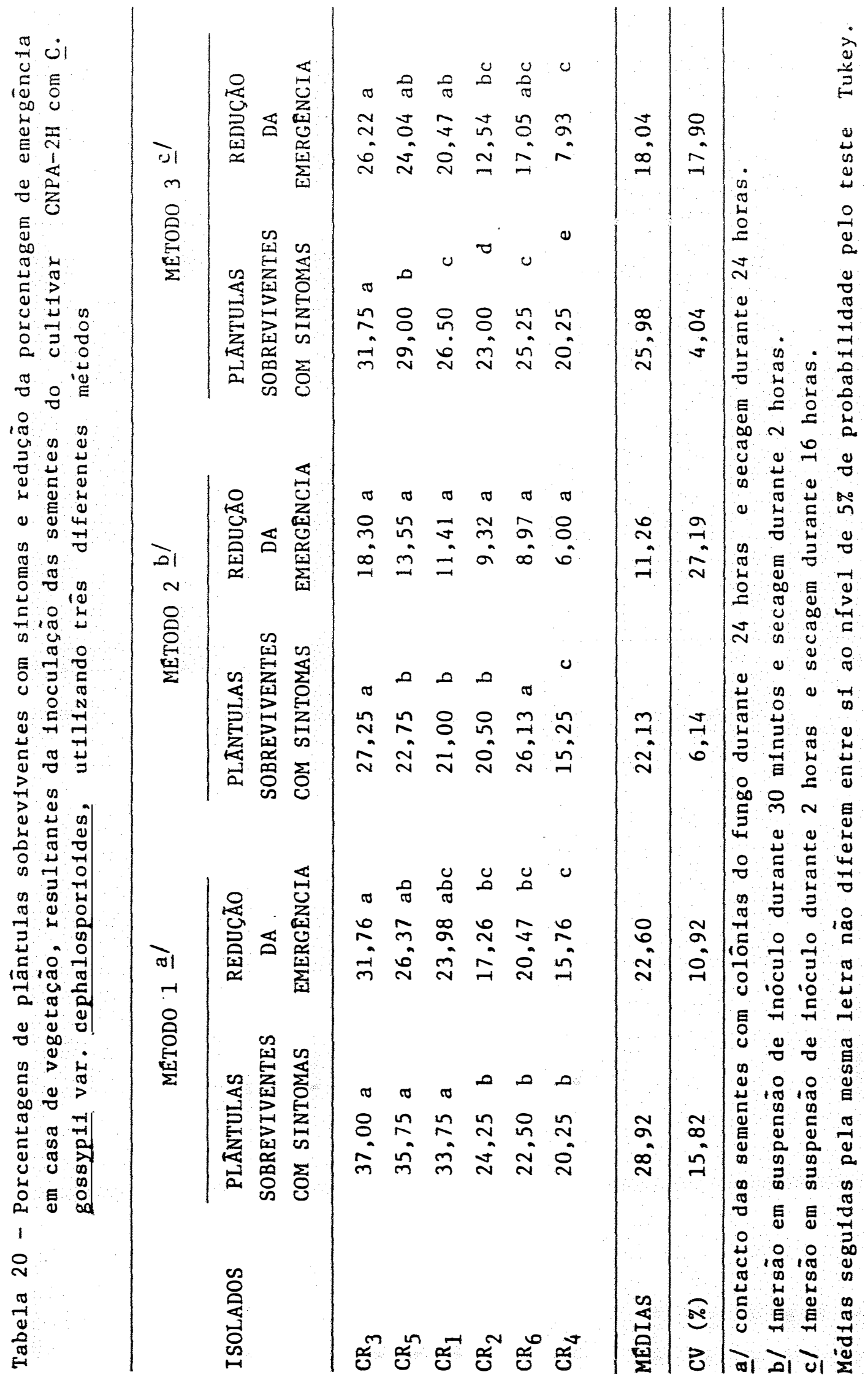


quanto aos parametros avaliados em cada método, exceto para redução da porcentagem de emergencia no método 2.

Os resultados obtidos para porcentagens de plantulas sobreviventes com sintomas evidenciaram.em todos os métodos. a maior pairejanicijade do isolado CR 3 , embora no método 1 os isolados $C R_{5} e C R_{1}$ tenham apresentado resultados semelhantes, sem diferenças significativas entre si. No método 2 . destacaram-se os isolados $C R_{3} e C_{6}$. que se apresentaram com patogenicidade semel hante. Para o parámetro em questão, em todos os 3 métodos, 0 isolado $C_{4}$ fol o menos patogénico. sendo que apenas no método 1 os valores obtidos para este isolado năo foram significativamente inferiores a todos os demais C Tabela 20s.

Considerando as reduç̧̃es da porcentagem de emergência, verifica-se na Tabela 20 que, embora a análise de variancia năo tenha evidenciado efeito significativo para o método 2 . nos trés métodos utilizados o isolado $\mathrm{CR}_{3}$ roi o mais patogénico. Nos métodos 1 e 3 pode-se observar que 0 isolado $C R_{9}$ não diferiu significativamente de CR. $C R_{1}$ e $C R_{\sigma}$

Para C. 8ossypit. os resultados referentes as porcentagens de plantulas com sintomas e redução das porcentagem de emergéncia encontram-se na Tabela 21.

Através da análise de variancia foram observadas diferenças significativas entre os valores obtidos para os parametros avaliados nos trés matodos. 


\begin{tabular}{|c|c|c|c|c|c|c|c|c|c|c|c|}
\hline 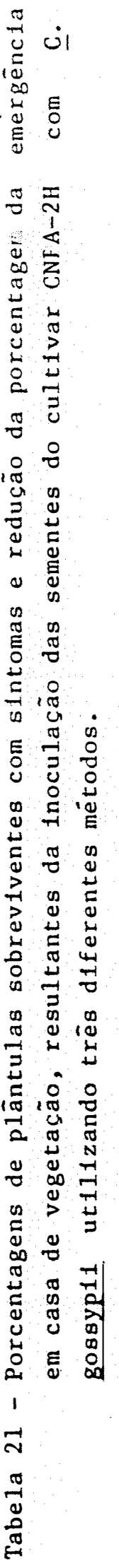 & $\begin{array}{c}01 \\
2 \\
8 \\
0 \\
0 \\
\frac{6}{2}\end{array}$ & 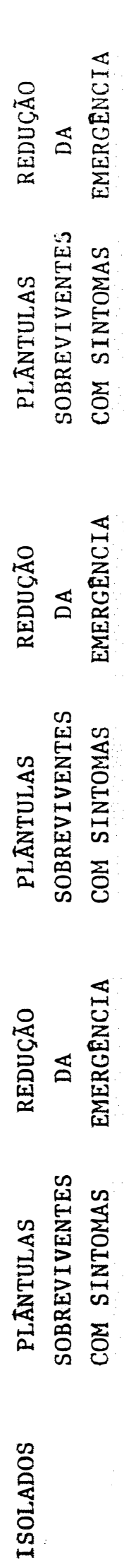 & $\begin{array}{l}n \\
\text { ñ } \\
\sim \\
\tilde{n}\end{array}$ & \begin{tabular}{l}
0 \\
0 \\
$\infty$ \\
$\infty$ \\
\multirow{\sigma}{0}{}
\end{tabular} & 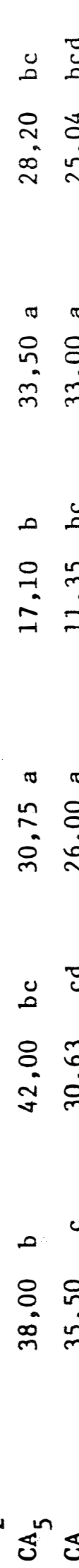 & $\begin{array}{l}0 \\
\tilde{0} \\
\hat{0} \\
0 \\
0 \\
0\end{array}$ & $\begin{array}{l}0 \\
\stackrel{m}{\tilde{m}} \\
\text { लें }\end{array}$ & $\begin{array}{l}0 \\
\text { ñ } \\
\text { ते }\end{array}$ & 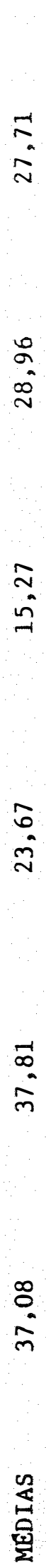 & O己 & 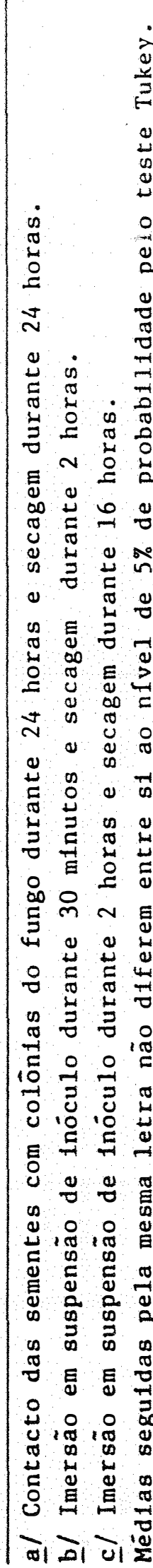 \\
\hline
\end{tabular}


No método 1 . os 1 solados $\mathrm{CA}_{2}$ \& $\mathrm{CA}_{3}$ destacaram-se como os mals patogenicos, tanto para porcentagem de plantulas com sintomas como para a reduçăo da porcentagem de emergéncia.

No método 2 . tambéri o isolado ch toi o mais patogénico. Este isolado năo diferiu significativamente de $C A_{5}-C A_{1}$ para 0 parkmetro porcentagem de plantulas com sintomas.

No método 3, também fol evidenciada a maior patogenicidade do 1 solado $\mathrm{CA}_{9}$ nos. dols parametros avaliados, sendo que para porcentagem de plantulas com sintomas este isolado não diferiu significativamente de $C A_{1} \odot C A_{5}$

Pela Tabela 21 pode-se observar que, embora nem sempre ao nivel estatistico, 0 isolado $C A_{6}$ comportou-se como o menos patogenico.

A análise de correlação entre a variável independente, esporulaçăo (Tabela 4). as variávels dependentes. Indice de doença (Tabela 6). porcentagem de redução da emergencia CTabela 20J. porcentagem de plantulas com sintomas CTabela zOS e porcentagem de sementes com C. sossypii var. cephalosporioidos CTabe12 14J. apresentou. respectivamente. os coeficientes de correlaçăo: $0.96,0.86,0.86$ e 0.95 , significativos ao nivel de $1 \%$ de probabilidade pelo teste $t$. Tendo como variavel independente o crescimento micelial. somente houve correlação signiflcatı́va com a variável dependente porcen- 
tagem de sementes com o patógeno $(r=0,58)$, ao nivel de $5 \%$ de probabilidade pelo teste $t$.

4.5. Patogentaldade de C. Bossypii e C. sossypii var. cephalosporioides - chro gentilivo de algodoelro, atraves da inoculacão de sementes.

4.5.1. Aralise de sanidade das sementes.

Os resultados obtidos encontram-se na

Tabela 22 .

A analise de variancia mostrou existirem difenças significativas entre os valores obtidos para os parametros avaliados. para os dols patogenos.

Os cultivares testados comportaram-se de maneira semelhante quanto as porcentagens de sementes mortas por ambos os patogenos, ou seja, os cultivares IAC-12-2 IAC-20 apresentaram os malores valores. diferindo significativamente dos demais. que por sua vez. năo diferiram entre si.

Quanto as porcentagens de raizes apodrecidas, a inoculaçăo com ambos os patógenos resultou em menores valores para os cultivares IAC-12-2 e IAC-20. A I inhagem Nu-15-79/117 e o cultivar IAPAR-4-PR-1 foram os genotipos mais afetados por C. eossypii var. cephalosporioides. Por outro lado, na inoculaçăo com C. gossypii a IInhagem Nu-15-79/117 e os cultivares I APAR-4-PR-1 e EPANIG-3 foram 


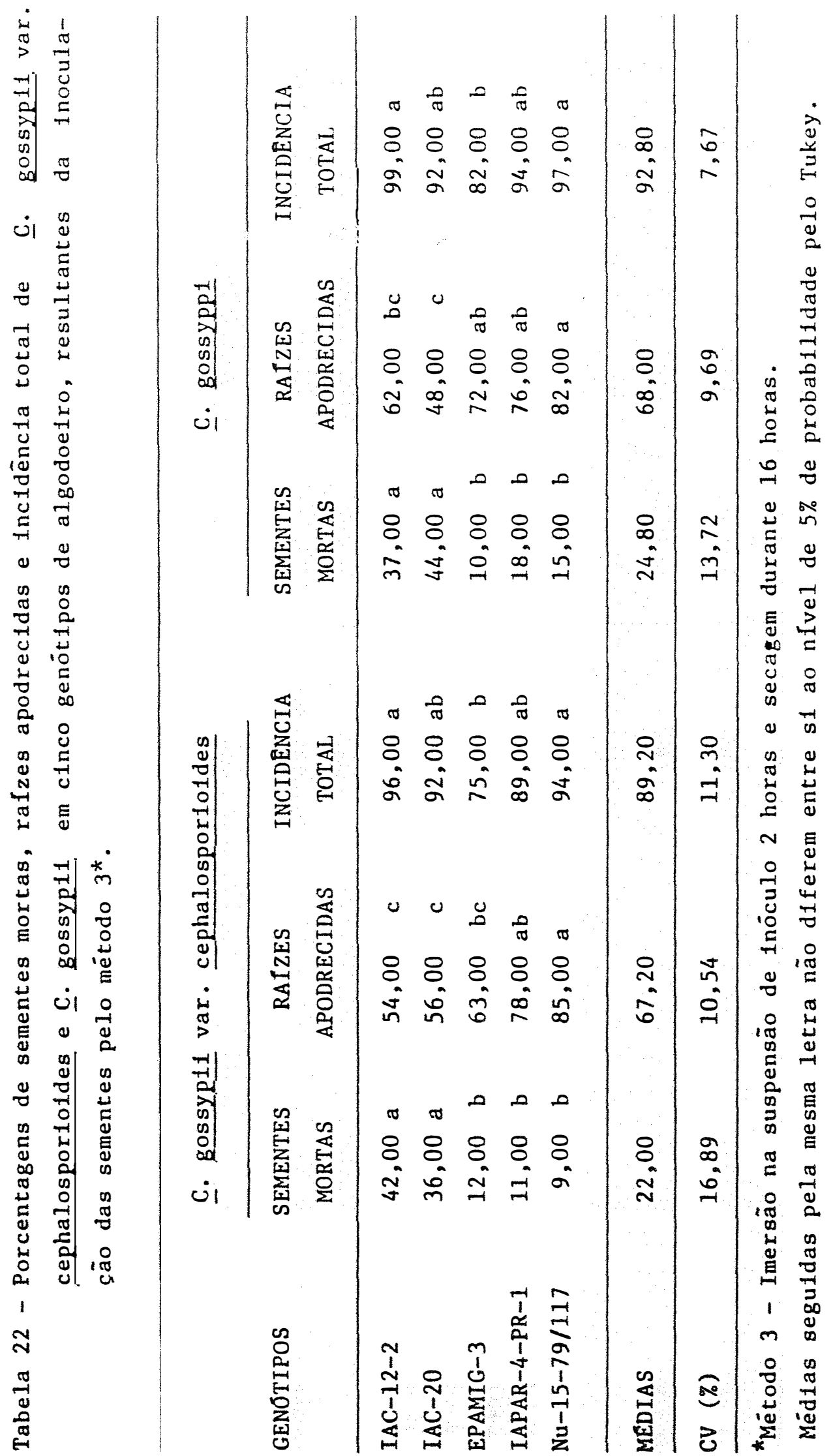


os mals afetados. năo diferindo significativamente entre si (Tabela 22).

A porcentagem de incidéncia total de ambos os patogenos fol significativamente maior no

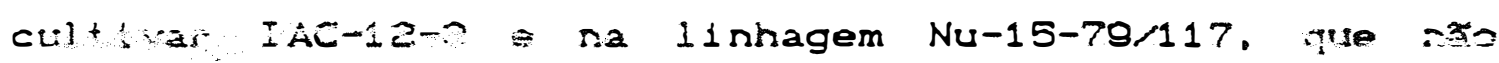
diferiram significativamente dos cultivares IAC-2O e I APAR-4-PR-1. Por outro lado. a menor incidéncia fol observada para o cultivar EPAMIG-3 (Tabela 22).

4.5.2. Emergência em casa de vegetação.

Os resultados obtidos encontram-se na

Tabela 23 .

A analise de variancia mostrou oxistirem diferenças significativas entre os valores obtidos para ambos os parametros estudados. para os dois patogenos.

Observou-se que para C. gossypii var. cepralosporioides os genotipos IAC-12-2 e Nu-15-79/117 comportaram-se como os mals suscetivels para ambos os parâmetros estudados. năo tendo diferido significativamente entre si. 0 cultivar EPAMTG-3 mostrou-se o mais resistente. enquanto que IAC-20 e IAPAR-4-PR-1 foram intermediarios (Tabela 23).

$\mathrm{Na}$ inọculaçåo com c. gossypit. o cultivar EPAMIG-3 comportou-se como o mais resistente em aubos os parametros. Para porcentagem de plantulas com sintomas o maior valor fol observado para a linhagem 
Nu-15-78/117, que nao diferiu significativamente do cultivar IAŨ-12-2. Quanto a porcentagem de reduçăo da emergencia. = cultivar IAC-20 e a I1nhagem Nu-15-78/117 apresentaram os malores valores. sendo estatisticamente semeits-te= entre si e entre os cult-vares TAC-I-2-2 e IAPAR-4-PR-1 (Tabela 23). 


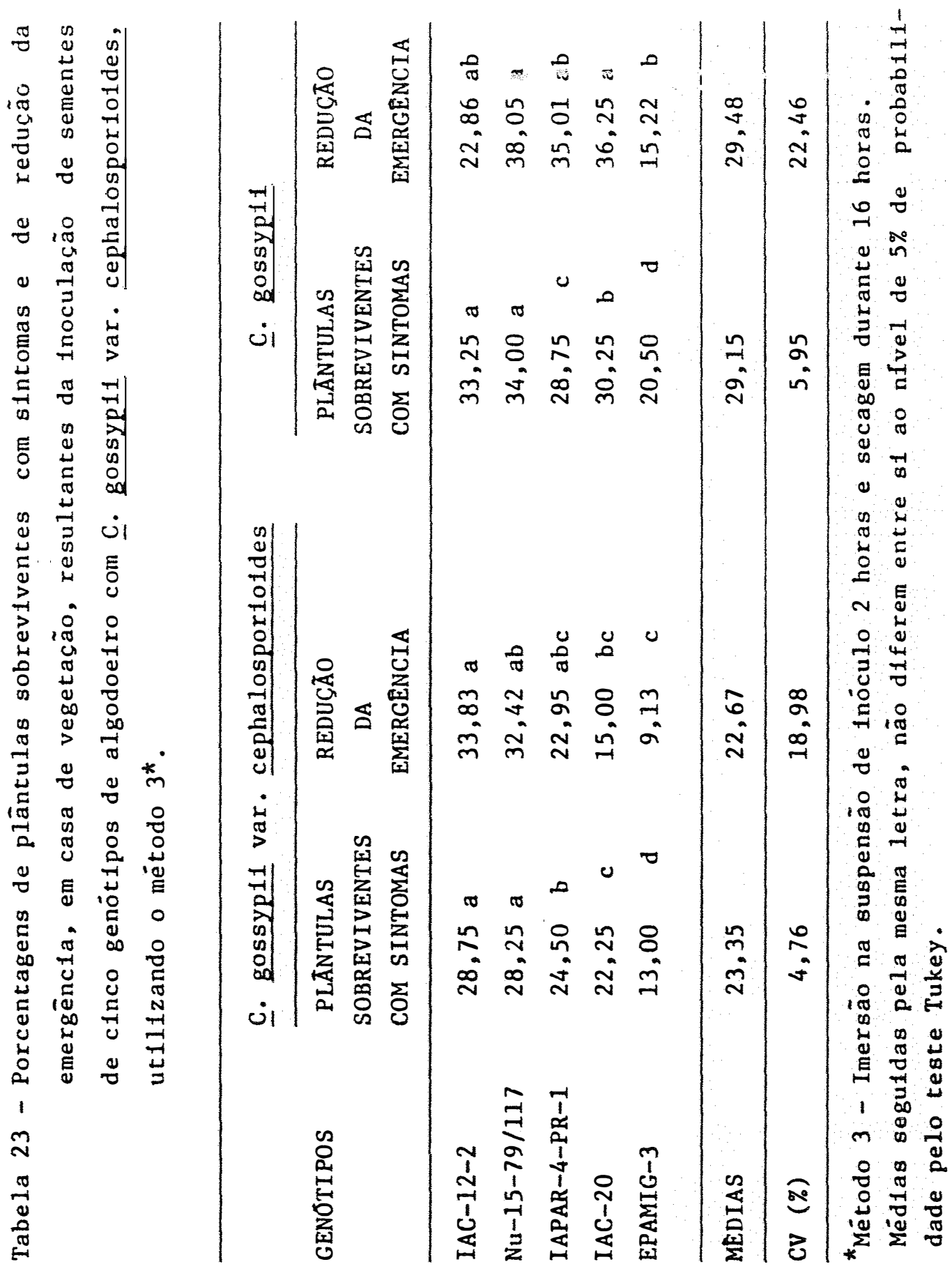


5. DISCUSSÃo.

5.1. Crescimento micelial e esporulaçăo in vitro de $C$. gossypii var. cephalosporioides e C. possypit.

Utilizando o meio BDA observou-se que houve variação no crescimento linear dos isolados dos dois patógenos em função dos intervalos de leitura. Ao final de 144 horas de incubação fol possivel detectar, atraves da análise de variancia. diferenças significativas tanto entre os isolados de C. gossypii como de C. gossypiz var. cepralosporioides (Tabelas 2 e 3 J.

Quanto a esporulação. o meio de aveía rol superior ao BDA para ambos os patogenos (Tabelas 4 e 5 ). Esse meio. de preparo relativamente fácil. possibilita a obtenção de grande quantidade de inóculo para utilizaçăo em testes que necessitem da inoculaçăo de plantas ou sementes.

o crescimento linear năo fol correlacionado com a esporulação para ambos os patógenos. isto é. nem sempre o isolado que apresentou maior crescimento fol o que mais esporulou e vice-versa.

Comparando o crescimento dos diferentes 
isolados de C. gossypii var. Cepinalosporioides (Tabela e) com os dados das Tabelas 6,14 e 20 , vorificou-so que nao houve correlaçao com a patogenicidade dos mesmos. 0 isolado CRa" embora com patogenicidade semelhante à de CR." apresurtou um cres-inento mais rápido em função dos 1 nuervalos de leitura. O isolado GR, com crescimento mais lento. nao roi o menos patogenico. Por outro lado. CR, o menos patogenico, nåo apresentou o crescimento mais lento. A ausencia de correlaça entre o crescimento e os dados das Tabolas 6 o 20 , confirmam essas obsorvagaos.

$$
\text { Para os isolados do } C \text {. gossypit }
$$

observou-se a mesma tendancia. O isolado CA, com crescimento maior em comparaçăo com os demais (Tabela 3), não foi, no entanto, o mais patogenico (Tabela 21 ).

Por outro lado, os dados da Tabela 4 , comparados com aqueles das Tabelas 6, 14 e 20, mostram que a esporulaçao dos isolados de C. sossypii var. cephalosporioides foi diretamente correlacionada com a sua patogenicidade.

LIMA (1881), comparando dois isolados de $C$. 8ossypii var. cephalosporioides, um de intensa o outro de baixa esporulaçao, verificou que eles estavam associados a alto e baixo Indice de tombamento, respectivamente. Embora - autor nåo tenta observado correlaçao entre esporulaça e patogenicidade para todos os isolados testados, os dados do presente trabaliho confirmam em parte aqueles resul tados. 
5.2. Patogenicidade de seis isolados de $C$. 8ossypii var. cophaiosporioides em plantas de nove genbtipos de algodoeiso.

As variaças de sintomas apresentiacias pelos genotipos do hospedeiro indicaram a grande variabilidade dos isolados testados, como pode ser observado na Tabela 6.

Foi observado que os isolados utilizados apresentaram patogenicidade variávol emi funçæo do genótipo no qual foram inoculados CTabela 6J. De modo geral, 0 isolado CR foi o menos patogenico. Os isolados CR, a CR. comportaram-se como os mais patogenicos, e os demais, como intermadiários.

Esses resultados estao de acordo com LIMA (18812, que, ao testar treze isolados de C. sossypii var. cephalosporioides em tres cultivares e sete linhagens de algodoeiro, observou haver variabilidade entre os isolados quanto à capacidade de provocar sintomas de superbrotamento. Ficou evidenciado que os genótipos tamberm variam na sua reaça aos diferentes isolados, levando o autor a sugerir a provável existoncia de racas do patogeno.

Os genótipos testados no presente trabaliho tambem variaram na sua reaçao diante da inoculaça com os diferentes isolados CTabela 6J. Os valores modios obtidos da inoculaça dos seis isolados, separadamente, em cada um dos nove genótipos destacou a cultivar EPAMIG-3 como o 
mais resisteile o a linhagem Nu-15-79/117 como a mais suscetivel. Esses dados. obtidos em casa de vegetaçăo. concordam com resultados relatados por CIA et alli C1882b; $1988 a$ a 1888b), PIZZNATIO \& CIA (1987) \& PIZINATIO

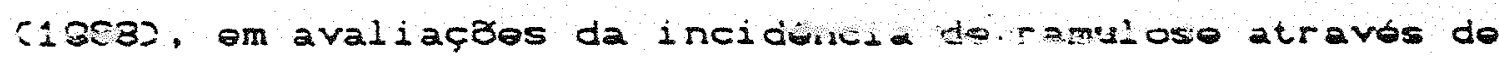
inoculaçß̋es em campo, utilizando os mesmos genttipos.

Confirmaram-se, portanto, as consideraçes de LIMA (1981), ao afirmar que provavelmente a inoculaçao de plantas em casa de vegetaço, empregando técnicas padronizadas, seja perfeitamente adequada à selecáo visando resistencia ao patógeno. Alia-so a estas observaços - fato de que o ambiente em casa de vegetaço $b$ mais controlado, as regas sao equilibradas e evita-se a contaminaça das plantas testemunhas, que frequentemente ocorre em experimentos de campo, mascarando as informaças obtidas.

No entanto, deve-se considerar que no campo, além da variaço da temperatura ser menor do que no interior da casa de vegetaça, ha a ocorréncia de orvalho, que pode ter um importante papel na manifestaçao da doen६a.

Sogundo VAN DER PLANK (1868; 1875; 18842 a existência ou nå de significáncia da interaça diferencial entre variedades do hospodeiro e isolados do patógono, permite a distincao entre dois tipos de racas patogenicas : racas virulentas o racas agressivas. As raças virulentas são caracterizadas pola significancia 
dessa interação, ou seja, pela impossibilidade de ordenamento dos isolados segundo sua patogenicidade. independentemente das variedades, ou destas segundo sua resisténcia, independente dos isolados. A inexisténcia

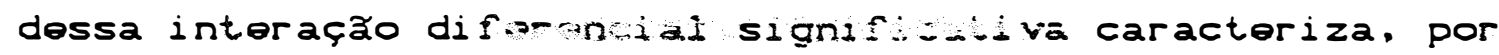
sua vez, as raças agressivas. A resistencia vertical horizontal såo consequencia da presença de raças virulentas e at isivas, respecti vamente.

No presente trabalho, cinco dos seis isolados utilizados diferiram significativamente om sua patogenicidade, expressa pelo indice de doença. Por sua vez, os genótipos, com excecão do cultivar EPAMIG-3, diferiram significativamente na resistencia à infecç̃o pelos diferentes isolados. A impossibilidade de ordenamento dos isolados em relaçăo aos genótipos $\theta$ destes, om relaça aos isolados, caracterizou a existoncia de raças virulentas de C. sossypii var. cephalosporioidos - resistencia vertical incompleta em algodoeiro CVAN DER PLANK, 1884 J.

Essa afirmação é reforçada pelo rato da resistancia do algodoeiro a ramulose ser monogenica CCARVALHO ot alii, 1888$)$ o por VAN DER PLANK (1068) ter caracterizado a resistencia vortical como sendo geralmente mono ou oligogenica. sustentado pela teoria gene-a-gene de Flor.

Em trabalhos visando seloça de plantas resistentes a ramul ose em condiçăo de campo, normalmente se 
utiliza mistura de isolados coletados em diversos locais onde ocorre a doença. Tal procedimento visa selecionar - plantas seï. resistencia raça-especifica, porém o resultado nåo indica necessariamente a natureza da resistencia, pois

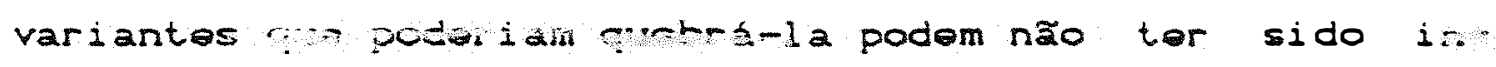
clufdos na mistura, por mais abrangente que tenha sido a coleta dos isolados. Desta maneira, evita-se a possibilidade de se usar um isolado com alta ou baixa patogenicidade, que poderia levar à interpretaç̧es erroneas.

Em decorroncia disso e com base nos resultados do presente trabalho, nos experimentos seguintes, realizados com o objetivo de testar a resistencia de diferentes genótipos 20 patógeno, foram utilizadas misturas dos isolados.

5.3. Transmissão de C. gossypii var. cephalosporioides pelas sementes de cinco genótipos de algodoeiro inoculados em dois estadios de desenvolvimento.

Por transmissao entende-se a transferencia do patógeno da planta-mäe para a semente Ctransmisszo planta-sementes ou da semente para a plantula (transmissao semente-plantulas. Por se tratar de uma associaçá biologica, a taxa de transmissao é bastante influenciada pelo ambiente e pelas caracteristicas inerentes do patogeno $\theta$ 20 hospedeiro. 
fæo de plantas doentes leva a se supor que o patógeno seja transportado pelas sementes produzidas, proporcionalmente a incidencia e à severidade de ocorrencia da doença. No entanto, relatos de literatura tem demonstrado quo nem somp ajtete oesa corralação positiva.

Os resultados do presente trabal ho mostraram que, embora a inoculaçåo 30 dias após a semeadura tenha resultado em maiores indices de doença. a incidencia do patógeno nas sementes foi maior quando a inoculaça foi ofetuada em plantas com maças formadas (Tabelas $7 \bullet 85$.

Esses resultados estzo de acordo LIMA et. alii (1885) que, inoculando plantas de algodoeiro em quatro épocas diferentes, tamben verificaram ausencia de correlaça entre severidade da doença e porcentagem de sementes portadoras do patógeno. Foi observado que as sementes das plantas inoculadas com maçs formadas transportaram o patógeno em maiores proporf̧es do que quando a inoculaça foi efotuada nas demais epocas. Ds autores concluiram que a semente adquire o patógeno atravos do seu contacto com tecidos da maça colonizados pelo fungo. Essa hipotese foi sustentada pelo fato do patógeno ter sido isolado de pequenas lesbes encontradas na superficie das maças.

Essas lesbes, mencionadas por LIMA et alii (1985), foram observadas nas maças das plantas inoculadas no presente trabalho, com mais frequencia quando a 
inoculaçăo foi efetuada no estádio de maçăs formadas. Em camara úmida, póde-se observar estruturas do patógeno nessas leszes, consubstanciando a hipótese de que as sementes foram infectadas ou contaminadas pelo contacto entaridos infectados da maça.

Essa de uma possivel explicação para os resultados encontrados, uma vez que as sementes produzidas nas maças com leşes provavelmente tiveram muito mais oportunidade de entrar em contacto com o patógeno e transporkz-10.

Esta hipótese a reforçada pelo fato da maioria dos fungos que infectam as plantas atingirem as sementes pela atuaça ativa sobre os tecidos do fruto ou da própria semente CMACHADO, 18882.

As sementes produzidas pelas plantas inoculadas no estádio de maças formadas resultaram em maiores porcentagens de redução da emergencia e de plantulas sobreviventes com sintomas (Tabelas o 102 . A inoculaçao nesse estádio resultou em maior transmissão semente-plantula. Ial resultado era esperado, uma vez que essas sementes apresentaram maiores porcentagens do patbgeno.

Dentre os genótipos testados o cultivar IAC-12-2, embora tenha ocupado o penúltimo lugar no ordenamento quanto a suscetibilidade (Tabola 72 foi o que produziu sementes com maior incidencia do fungo. Como consequência, para este cultivar foram observadas maiores 
porcentagens de redução da emergencia e de plántulas com sintomas (Tabelas \& 810 .

A inoculaçåo das plantas no estádio de maças formadas resultou, para todos os genótipos, om maiores porcentagens to trausuifsir do patógono polas sementes em comparação com a inoculaçã aos 30 dias após a semeadura (Tabela 11). As porcentagens de transmissáo podem ser consideradas al tas, mesmo para o cultivar EPAMIG-3, - genótipo mais resistente.

- conhocimento do estadio do dosenvolvimento das plantas no qual a infecço se traduz em maior transmissão para as sementes, e destas para as plantulas, pode ser de grande valor em trabalhos de inspecáo sanitaria de campos. Essas informaços pormitem determinar em que época a incidencia da doença na planta pode significar maiores riscos de contaminação ou infecद̧o das sementes (MACHADO, 1888 ).

A Iinhagem Nu-15-78/117, o genótipo mais suscetivel (Tabela 7), apresentou a maior porcentagem de transmissão pela semente. Porom, contrariamento ao esperado. a porcentagem de transmissão mais baixa nåo foi observada para o cultivar EPAMIG-3, o genótipo mais resistento, o sim, para o cultivar IAC-12-2.

Sogundo MENTEN (1885). generalizando. quanto maior a resistencia da planta-mae, monor será a transmissão do patógeno para a semente, como tambóm menor será a transmissao dessa semente para a plantula. No entanto, 
os mecanismos de infeç̧o das sementes e de transmissão podem ser independentes da suscetibilidade da planta-ma.

Pela Tabela \& verifica-se que para 0 cultivar IAC-12-2 a presença do patogeno nas sementes originou mai-- polvęa d. porconłagem de emergencia, em relaça a des demais genótipos. Os seja. para este cultivar = ereito do fungo o imediato, matando a plantula. Em decorrencia disso, os genótipos com menor roduça da emergencia deram origem a plantulas sobreviventes com sintomas em maiores proporgbes do que as obtidas para o cultivar IAC-12-2, o que se verifica comparando as Iabelas 8 - 10. E como a porcentagem de transmissão foi calculada baseada noe dados destas duas tabelas, evidoncia-se a coerencia dos resultados obtidos, aparentemento contraditorios, para o cultivar IAC-12-2.

PIZZNATIO ot alii (1088), vtilizando as genotipos EPAMIG-3, IAC-12-2, IAC-10 9 Nu-15-70/117. inoculados com C. sossypii var. cephalosporioides em condiços de campo, verificaram que o cultivar IAC-12-2, embora tenha dado origem a sementes com maiores porcentagens do patogeno, aprosentou a mais baixa taxa do transmissão, calculada atravos da porcentagem do plantas adultas com sintomas notas 4 a Polos resultados do presente trabalho. podo-so supor que a prosenca do patógeno nas sementes do cultivar IAC-12-2 rosultou om maior reduço da emergencia do que nos demais genótipos. Nestes, a mnior sobrevivoncia de plantulas infoctadas podo 
ter originado, proporcionalmente, maior número de plantas adultas com sintomas, que foram consideradas no cálculo da taxa de transmissão, originando os resultados encontrados.

$$
\begin{aligned}
& \text { 5. 4. Compara-20 de métodos de inoculaç̃o de -.mantos } \\
& \text { com C. 8ossypii var. tephalosporioidos o C. } \\
& \text { gossypii. }
\end{aligned}
$$

A assepsia superficial permitiv verificar se os patógenos estavam interna ou externamento associados às sementes, e portanto, a eficiencia do método na obtença de sementes infectadas. Para esta finalidade. o método 1. que consistiu no contacto das sementes com colonias do fungo, mostrousse o mais eficiente, seguindo-so os mbtodos 3 (imersao 2 horas e secagem 18 horas) e 2 (imersăo 30 minutos o secagem 2 horasl, conforme as tabelas 150 19.

Na natureza, a maneira mais comum de associação de patogenos com as sementes e o transporte interno, com o inoculo presente nas camadas mais internas ou no embriå. E, portanto, de grande interesse a obtenç̃o de sementes infectadas, de maneira semelhante a que ocorre naturalmente, para serem utilizadas em trabalhos sobre transmissão ou epidemiologia.

Os métodos 2 e 3 , com algumas variaçôs, têm sido usados com relativa frequencia para inocular sementes de algodao com colletotrichun CBALMER ot alii, 
1866; HALFON-MEIRI \& VOLCANI, 1977 ; LIMA, 1881 ; FOLLIN \& MANGANO, 18832 . O método 1 , já utilizado por COSTA (10302. - avaliado com mais detalhes por IANAKA et alii (1887), nao tom sido utilizado.

Considerando que o grat de umidedh tes sementes deslintadas e com assepsia ccondigăo antes da inoculaçå) era de $\beta, 1 \%, a$ inoculaçăo com os métodos 1,2 - 3 elevou essa umidade em 3,8, 2,6 e 5,8 pontos percentuais, respectivamente. Após armazenamento durante um mos om condiços do laboratório, om sacos do papol. a umidado das sementes inoculadas pelos métodos 1 o estava praticamente idsntica à das sementes que sofreram apenas assepsia. As sementes inoculadas pelo método 3 , apos o mosmo periodo de armazenamento encontravam-se com $11.2 \%$ de umidade, portanto 2,1 pontos percentuais acima da umidade das sementes nao i noculadas.

Consequentemente ressalta-se como desvantagem do método 3 um acréscimo no grau de umidade das sementes, provocado pela imersao das mesmas na susponsao do inóculo durante duas horas. Essa elevaçă da umidade pode provocar a perda da viabilidade das sementes e impossibilitar o seu armazanamento. No ontanto, essa desvantagem nå e relevante se as sementes forom utilizadas logo após a inoculaço, como aconteceu no presente trabalho. E como vantagens doste método podem ser citadas a possibilidade de se utilizar inóculo com concentraço contocida o dosojada. al ém da eficiencia na obtença de sementes infoctadas. 
- mótodo 2, por sua voz, ombor nå apresente o inconveniente da elevaça do grau de umidade $\theta$ permita padronizar o inoculo na concentraça desejada. foi - menos eficiento na obtença do sementes infoctadas.

o método 1 +rosanta mantagens a facilidade de execuçå, a oficioncia na infoção nas sementes e a pequena elevaçá do grau de umidade, permitindo o armazenamento das sementes infoctadas e nåo restringindo o seu uso para logo apos a inoculaça. Nos outros dois métodos, principalmente no método 2 , grande parte do inesulo fica em associaço externa com as sementes, com menor possibilidade de ocorrer infecça da plantula que dela será originada. Além disso, a semente apenas mol hada na suspensao de indeulo,20 ser secada ao ar, poderá resultar na morte da maioria dos conflios por rossecamento. Evidencia-se como desvantagem do mótodo 1 a impossibilidade de padronizaçăo do inóulo, o que inviabiliza a sua utilizaçăo quando é necessário misturar diferentes isolados em quantidades iguais a na mesma soncentração.

5.5. Patogonicidado do C. soeoypii o C. goopypit var. cephalosporioides a cinco genótipos de algodoeiro, através de inocul acäo das sementes.

Para esta otapa do trabal ho, ombora 0 mbtodo 1 tenha se mostrado o mais erleiento na obtencro de 
sementes infectadas, o método 3 foi escolhido por permutir a infecção das sementes em ni vel satisfatorio e utilizaçăo do inóculo na concentração desejada.

Comparando os dois patógenos. em valores médios, o ofetode C. gosss.t sobre os parametros avaIiados foi maior, apesar desta comparaço năo ter sido feita ao nivel estatistico (Tabelas 22 e 23). Estes dados confirmam observaços feitas por FOLLIN \& MANGANO (1983), que consideraram $C$. sossypii muito mais patogennico que $C$. sossypii var. cephalosporioides, em virtude do primeiro ter provocado sintomas mais severos e com maior rapidoz. Os citados autores afirmaram que a infeç̧o por C. gossypii var. cephalosporioiodes resulta em menor porcentagem de plantulas mortas, provenientes de sementes inoculadas por método bastante semelhante ao do presente trabalho, num perfodo de dez dias de observaçăo. No entanto, essas afirmaçoses foram baseadas em apenas um isolado de cada patógeno.

Pelos resultados das Tabelas 12 a 21 observa-se que houve grande variaçao na patogenicidade dos isolados testados. So nesta etapa do trabalho tivessem sido utilizados os isolados CA de C. sossypii lo mais patogenicos e CR de C. gossypii var. cephalosporioides co menos patogenicos, 20 invés de uma mistura de isolados de cada patogeno, provavol monte os rosultados so aproximassom ainda mais daqueles de FOLLIN \& MANGANO ( 19832.

Confrontando os resultados da Tabela 23, 
referentes a C. eossypii var. cophalosporioides, com aqueles das Tabelas a e 10. observa-se que a inoculaça artiricial das sementes resultou em efeito muito mais drástico do patogeno do que a associaça natural, através da planta doert,. Verillica-ts, portm, que o comportamento dos gene tipos testados seguiu a mesma tendencia. Assim, o cultivar EPAMI G-3 comportou-se como o mais resistente no estádio de plantula, enquanto que o cultivar IAC-12-2 e a linhagem Nu-15-79/117, como os mais suscetiveis. Os cultivares IAC20 - IAPAR-4-PR-1 ficaram, de modo goral, om posiça intermediária.

Os resultados das Tabelas $\&, 10$ a 23 podem ser comparados com aqueles da. Tabela 7 , que retrata o comportamento dos mesmos genótipos quanto ao superbrotamento em plantas adultas. Observa-se que o cultivar EPAMIG-3 O a Iinhagem Nu-15-70/117 foram os genótipos mais resistente o mais suscetivol. respectivamente, tambem em planta adulta. Os cultivares IAC-20 e IAPAR-4-PR-1, de modo análogo, permaneceram em posiça intormediaria. No entanto, o cultivar IAC-12-2 comportou-se como moderadamente resistente 20 superbrotamonto, tendo sido o mais suscetsvol no cetadio de plantula.

Este resultado pode ser interpretado de modo semolhante 20 adotado para os dados da Iabola 0 . Os seja, a associ aça do patógeno com as sementes do cultivar IAC-12-2 tom un of eito imodiato, matando as plantulas. 


$$
\text { Esses resultados confirmam evidancias }
$$

encontradas por LIMA (1881) que, trabalhando com o mesmo patógeno, inoculado em tres cultivares e sete linhagens de algodoeiro, concluiu que provavelmente uma planta resistonte 20 tombamento não $\&$, necessariamonto rasiatento 20 superbrotamento, e vice-versa. 
6. CONCLUSÕES.

Os resultados obtidos no presente trabal ho permitiram extrair as seguintes conclusbes :

- A patogenicidado dos isolados tostados, de ambos patógenos, nao foi correlacionada com o seu crescimento linear, havendo, no entanto, corrolaça positiva entre a esporulaçăo a patogenicidado.

- Existe variaço fisiológica a patogenica entre isolados de C. gossypii a C. gossypit var. cephalosporioidos o variaço na rosistoncia oxibida por diferentes genótipos de algodoeiro aos patógenos.

- Evidenciou-se a ocorrencia de raças virulentas de C. gossypii var. cophaiosporioidos e resistoncia vertical incompleta no hospedeiro.

- A inoculação no estádio de maças formadas, comparada à inoculaço 30 dias após a semoadura. rosultou em maior associaço do patógeno com as sementos produzidas.

- Nem sempre a resistencia a ramulose em planta adulta foi correlacionada com a resistoncia no estádio de plantula, com a porcentagem do patógeno nas semontes, ou com a porcentagem de transmissao semento- plantula. 
- O método de inoculaça de sementes que consistiu no contacto das mesmas com culturas dos fungos durante 24 horas, seguidas de secagem por 24 horas. apresentou maior eficisncia na obtençao de sementes infectadas. 
7. REFERFMCTAS DIDITXGRAFTCAS.

ABRAHzO, J. Manifestaço tardia da ramulose ou superbrotamento do algodoeiro. O Biolbgico, Sa Paulo,18:135-138. 1952.

ABRAHZO, J. Combate à ramulose tardia do algodoeiro. 0 Biolbgico, Sao Paulo, 27: 121-123, 1861 .

ABRAHZTO, J. \& COSTA, A.S. Instruç80s para 0 reconhecimento da "ramulose" do algodoeiro. O Biolbgico, Sio Paulo, 15:58-60, 1848.

ARANTES, E.M.; FUZATIO, M.G.; CHI AVEGATO, E.J.; CIA. E. Comportamento de variedades nacionais de algodoeiro em Mato Grosso, na presença de ramulose. In: REUNIJ̃o NACIONAL DO ALGODEO, 4., Bel em, 1986. Resumo. Bel ém, EMBRAPA. 1086 . P. 25.

ARAúJo, F.E.; CAVALCANIE, R.D.; CaVAlcaNte, M.L.S. Ccorrancia de ramulose em algodoeiro herbacoo no Ceará. Fitossanidade, Fortaleza, 2:80, 1878.

ARNDT, C.H. Effoct of storage conditions on survival of Colletotrichzon sossypii. Phytopathology, St. Paul. 36: 24-20, 1046. 
BALMER, E.; SALGADO, C.L.; CIA, E.; CAMPOS, H. Efoito do potencial de inoculo de Colletotrichm sossypii South. sobre o tombamento das mudinhas do algodoeiro. Arais da E.S.A. "Luiz de : juiroz", Piracicaba, 23: 325-338, 1966.

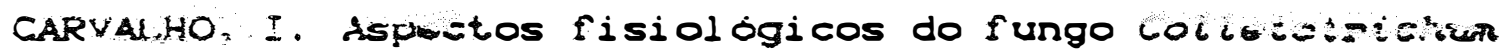
8ossypi South. .... cephalosporioides Costa. Revista da Sociedade Brasileira de Fitopatologia, 4:1-2, 1871 .

CARVALHO, L.P.; G.RVALHO, J.M.F.C.; LIMA, E.F.; CAVALCANTE, F.B. Inflluencia da concentraçZo de esporos na patogenicidade de Collototrichum sossypii South. var. cephalosporioidse A.S. Costa o avaliaçio da resistencia de cultivares o linhagens de algodooiro herbáceo a ramulose. Fitopatologia Brasileira, Brasilia, 6: 385-402, 19812.

CARVALHO, L.P.; CAVALCAVTE, F.B.; LIMA, E.F.; CARVALHO, J.M.F.C. Determinaça de motodo de amostragem na avaliaça de ramulose no algodoeiro em condicbos de campo sob infeccao natural. Fitopatologia Brasileira, Brasilia, 6: 403-407, 1081 b.

CARVALHO, L.P.; CAVALCANTI, F.B.; LIMA, E.F; SAVTOS, E. O. Influoncia da ramulose nas caracterfsticas de flbra e produçzo do algodoeiro. Fitopatologia Brasileira, Brasilia, 9:583-598, 1884.

CARVALHO, L.P.; LIMA, E.F.; RAMALHO, F.S.; LUKEFAHR, M.J.; CARVALHO, J.M.F.C. Influéncia da pilosidado do algodoeiro na expressao de sintomas de ramulose. Fitopatologia Brasiloira, Brasilia, 10:640-654, 1088. 
CARVALHO, J.M.F.C.; LIMA, E.F.; CARVALHO, O.S.; CARVALHO, L.P. Identificaço de fonte de resistencia à ramulose em Iinhagens de algodoeiro. In: REUNIZO NACIONAL DO ALGODZO, 4. , Bel $\mathrm{em}, 1886$. Resumo. Bel em, EMBRAPA-CNPA, 1986. P. 105.

CARVALHO, L.P.; LIMA, E.F.; CARVALHO, J.M.F.C.; MOREIRA, J. A.N. Herança da resistencia à ramulose do algodoeiro (Colietotrichum sossypii var. cephaiosporioidoss. Fitopatologia Brasileira, Brasflia, 13:10-15, 1988.

CIA, E. Ocorrancia e conhecimento das doenças de algodoeiro anual Gossypium hirsutum L. no Brasil. Summa Phytopathologica, Piracicaba, 3:187-193, 1877.

CIA, E. ; GRIDI-PAPP, I.L. ; FUZATIO, M.G. AvaliąIO do linhagens o variodados para resistoncia múltipla a doonças do algodoeiro. In: REUNI ZO NACIONAL DO ALGODZO, 2. . Salvador, 1082. Resumo. Campina Grande. EMBRAPA CNPA, $1882 a$. p. 230.

CIA, E. ; FUZATIO, M.G.; GRIDI-PAPP, I.L.; SOAVE. I. ; CIONE, J. Avaliaça da incidoncia de ramulose do algodoeiro atraves de inoculaçao artificial. In: REUNIZOO NAGIONAL DO ALGODTO, 2., Salvador, 1982. Resumo. Campina Grande, EMBRAPA-CNPA; 1 882b. p. 241.

GIA, E.; FUZATTO, M.G. ; GRIDI-PAPP, I.L.; CHIAVEGATO, E.I.; DUDIENAS, C.; CAMARGO, A.P.; CAMPANA, M.P. ; LELIS, L.G. Comportamento dos materiais gentilicos estudados nos ensaios nacional e regional paulista de variedades em $1086 / 87$ em face de doenças e nomatóldes. Ia: REUNITO NACIONAL DO ALGODTO, 5., Campina Grande, 1988. Resumo. P.27. Campina Grande, EMBRAPA-CNPA, 18882. P. 27 . 
GIA, E. ; FUZAITO, M. G. ; GRIDI-PAPP, I.L.; CHI AVEGATO, E.J.: DUDIENAS, C.; CAMARGO, A.P.; CAMPANA. M.P.; LELIS, L.G.L.; BORTOLETIO, N.; PAULO, E.M.; KASAI. F.S. Comportamento de materiais geneticos estudados nos ensaios nacional o regional paulista de variedados em $1987 / 88$ em face das doenças * nematoides. In: REUNI Z̃o NACIONAL DO AlgODÃo, 5., Campina Grande, 1888. Resumo. p. 28. Campina Grande, EMBRAPA/CNPA, $1988 \mathrm{~b}$. p. 28.

COSIA, A.S. Infestaça de sementes de algodoeiro com Colletotrichwn sossypii South. Q C. 8ossypii var. cophalosporioidos. Jormal da Agronomia, Piracicaba, 2: 265-272, 1030.

COSTA, A.S. Investigaç8es sobre a ramulose. Relatório da Seça de Algodão do Instituto Agronomico de Campinas. 42p. . 1841 .

COSTA, A.S. \& FRAGA JUNIOR, C.G. SUpOrbrotamonto ou ramulose do algodoeiro. Revista de Agricultura. Piracicaba, 12:240-252, 1037.

COSIA, A.S. \& FRAGA IUNIOR, C. G. Sobre a natureza da ramu$10 s \theta$ ou superbrotamento do algodoeiro. Jornal de Agronomia, Piracicaba, 2: $151-160,1939$.

COSTA, A. S. \& SAVTOS NETO, J.A. 0 deslintamento das sementes de algodão pelo acido sulfurico em comparaço com outros tratamentos. Rovista do Agricultura, Piracicaba, 15: 120-132, 1940.

DHINGRA, O.D. \& KUSHALAPPA, A.C. No correlation botwoen angular leas spot intensity and seod infoction in boon by Isariopis 8riseola. Fitopatologia Brasileira, Brasilia, 5: 140-152, 1080. 
DHINGRA, O. D. ; FERNANDEZ, C. M. A.; KUSHALAPPA, A. C. LaCK of relationstip between field incidence of been anthracnose and production of seods, transmitting Colletotrichum indemuthianum.

Fitopatologia Brasileira, Brastlia, 11:85-101, 1886.

FIGUEIREDO, M. B. Estudos sobre a aplicaço do método de Castellani para conservaçao de fungos patógenos om plantas. O Biolbgico, Säo Paulo, 33:8-13, 1987.

FOLLIN, J.C. \& MANGANO, V. Etude sur la ramulose du cotonnier. Cotton et Fibres Tropicales, Paris, 38: 208-215, 1883.

GOMES, I.C. Avaliaçao da reaço de cultivares de foi jao CPhaseolus vulgaris L.J a raça alfa de Colletotrichum indomuthianum (Sacc. \& Magn.) Scrib. o transmissao do patógeno por sementes. Viçosa, 1070. 113p. CMestrado-Uni vorsidade Foderal de ViçosaluFV.

HALFON-MEIRI, A. \& VOLCANI, Z. A combinod mothod for detecting Colletotrichum sossypii and Xanthomonas malvacearwm in cotton sood. Soed Science and Tehnology, Zurich, 5:128-138, 1877.

KIMATI, H. Doenças do algodooiro - Gossypiun spp. In: GALLI, F., od Manual de Fitopatologia. Sa Paulo, Editora Ceres, 1080 . Vol. II, P. 28-48.

KUROZAWA, C.; NAKAGAWA, I.; DOI, I.; MELOTIO, E. Comportamento de 13 cultivares de gergelim CSoscmm indicuo a Cercospora sescmi, sua transmissibilidado por sementes e controle. Fitopatologia Brasileira. Brasilia, 10:117-122, 1885. 
LASCA, C.C.; ROLIM, P.R.R.; BRIGNANI NEIO, F.; ROSTON, A.J. Estudos preliminares sobre a relaço ontro ocorrsncia de antracnose em cultura de feijao $\theta$ infecço de sementes por Colletotrichwn lindomuthiarum. Fitopatologia Brasileira, Brasilia, 5: 412, 1880.

LIMA, E.F. Variabilidade de Collototrichum gossypii South. var. cophalosporioidos A.S. Costa o avaliagáo da resistancia de linhagens de algodoeiro a ramulose. Vicosa. 1981. 47p. CMestrado-Universidade Federal de Vicosa UFV.

LIMA, E.F.; GARVALHO, L.P.; SANTCS, E. O.; CARVALHO, J.M.F.C. Avaliaço de germoplasma de algodoeiro para resistancia a ramulose causada por Collototrichum gossypii var. cephalosporioidos. Fitopatologia Brasileira, Brasilia, 9: $561-565,1884$.

LIMA, E.F.; CARVALHO, J.M.F.C.; GARVALHO, L.P.; COSTA, J.N. Transporto o trasmissibilidado de Collototrichum 8ossypii var. cophalosporioides, atraves da semente do algodoeiro. Fitopatologia Brasileira, Brasilia. 10:88-108, 1885 .

LIMA, E.F.; GARVALHO, L.P.; CARVALHO, J.M.F.C. SOl OC:O para resistóncia a ramulose om algumas cultivaros $\theta$ linhagens de algodoeiro CG. hirsutum L. r. latifolium HUTCHS. In: REUNITO NACIONAL DO ALGODAO, 4., BOI 1886. Reswno. Bol fm, EMBRAPA, 1086. p. 104.

LIMA, E.F.; CARVALHO, J.M.F.C.; CARVALHO, L.P. Sobrevivencia do Colletotrichum sossypii var. cophalosporioidos em sementes de algodoeiro CGossypiem hirsutun L. r. latifolizon. Fitopatologia Brasileira, Brasilia, 13:247-248, 1888. 
LUDWIG, C. A. Studies of anthracnose infection in cotton serd. Phytopathology, St. Paul, 14:52, 1024.

MACHADO, J.C. Patologia de Somentes: fundamentos aplicaçßes. Brasiliz, Ministerio da Educaçao, ESAL FACDF, $1388.107 p$.

MALAGUTI, G. La escobilia del algodon en Venezuela. Agronomia Tropical, Ma-acay, 5:73-83, 1855.

MARCOS FILHO, J.; GICERO, S.M.; SILVA, W.R. AValiaçZ̃o da qualidade das sementes. FEALQ, Piracicaba, 230p., 1887.

MATHIESON, J.T. \& MANGANO, V. Ramulose, a now cotton disease in Paraguay caused by Collototrichum gossypii var. cophelosporioidos. Sumba Phytopathologica, Piracicaba, 11:115-118, 1885.

MCKINNEY, H. H. Influence of soil temperature and moisture on infection of wheat seodlings by Helminthosporium sativum. Jour. Agric. Res., Washington, 26:108-210, 1023.

MENTEN, J.O.M. Importancia da semente na transmissáo de patógenos. In: SIMPOSIO BRASILEIRO DE PATOLOGIA DE SEMENTES, 2. , Campinas, 1886. Resumos. Campinas, Fundaça Cargill, 1086. p.17-8.

NEERGAARD, P. Soed Pathology. London, MCMillan Press. Z ๑d. , 1878. 1180p.

PIZINATIO, M.A. Testes de sanidade de sementes de algodao. In: SOAVE, J. \& WEIZEL, M.M.V.S., od. Patologia de Sementes. Campinas, Fundaçao Cargill, 1887, p. $331-346$. 
PIZINAI:O, M.A. \& CIA, E. Relaç̃o entro incidencia do ramulose do algodoeiro em campo $\theta$ deteç̧o de $C$. sossypii var. cephalosporioides em sementes. Summa Phytopathologica, Piracicaba, 13:15, 1887.

PIZINATIO, M.A.; CIA, E.:. FUZA2.0, M. E. Estudos preliminares sobre a transmissao de C. gossypii var. cophalosporioidos por sementes do algodáo o sua disseminaço em campo. Fitopatologia Brasileira, Brasilia, 13:111, 1888.

IANAKA, M.A.S. Doenças do algodoeiro. Informo Agropocukrio, Belo Horizonte, 02: 70-73, 1082.

IANAKA. M. A.S.; MARI ANO, M.I.A.; MENIEN, J. O. M. InoCul aço artificial de sementes de algodaro com collototrichum gossypi var. cophalosporioides o infecfá das semontes em runça do tempo de exposi ç̃o. Suma Phi topathol ogica Jaguari úna, 15: 232-237, 1880.

TOFFANO, W.B. \& SILVEIRA, A.P. Fusariose o ramulose do algodoeiro. Campinas, Secretaria de Agricultura do Estado de So Paulo, DAIESIR, serie D/n- 8. 16p.. 1964.

VAN DER PLANK, J.E. Disease Resistance in Plants. New York, Academic Press, 1968. 206p.

VAN DER PLANK, J.E. Principles of Plant Protection. Now York. Academic Press, 1075. 216p.

VAN DER PLANK, J.E. Disease Resistance in Plants. Z. od. Orlando, Academic Press, $1884.194 \mathrm{p}$.

WATKINS, G.M. Compondium of Cotton Diseases. SL. Paul. The American Phytopathological Society, 1881. 87p. 
8. APÊNDICE.

$$
\begin{aligned}
\text { Apondice } 1 \text { - Diforenças minimas significativas CDMSO, } \\
\\
20 \text { nivel de } 5 \% \text { de probabilidade pelo tes- } \\
\text { te Iukey, utilizadas nas médias das Tabo- } \\
\text { las } 2 \text { a } 23 .
\end{aligned}
$$

\begin{tabular}{|c|c|c|}
\hline IABELAS & MEDI AS COMPARADAS & DMS $^{\circ}$ \\
\hline 2 & Isol ados incubados após $144 \mathrm{~h}$. & 0,20 \\
\hline 3 & Isol ados i noubados apos $144 \mathrm{~h}$. & 0,10 \\
\hline 4 & Isol ados & 0,66 \\
\hline 4 & Meios do cultura & 3.73 \\
\hline 4 & Isol ados dentro de meios de cultura & 13,86 \\
\hline 4 & Meios dentro de isolados & 0,13 \\
\hline 5 & Isol ados & 17,12 \\
\hline 5 & Meios de cultura & 6,60 \\
\hline 5 & Isol ados dentro de meios de cultura & 24.21 \\
\hline 5 & Moios dentro do isolados & 16.18 \\
\hline 6 & Genótipas & 3,87 \\
\hline 6 & Genótipos dentro de isolados & 0,47 \\
\hline 7 & Genótipos & 0,21 \\
\hline 7 & Epocas de inocul açăo & 2,34 \\
\hline 7 & Genótipos dentro de épocas & 7.38 \\
\hline 7 & Epocas dentro de genótipos & 8.22 \\
\hline 8 & Genótipos & 4.17 \\
\hline 8 & Epocas de i nocul ação & 1,88 \\
\hline
\end{tabular}


Continuaçăo

TABELAS

8

5

8

8

8

8

10

10

10

10

12

12

13

13

14

14

15

15

15

15

16

17

18

18

10

18

18

20

20
MEDI AS COMPARADAS

DMS

5,80

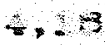

epwas viniro de genótipos

0,37

Epocas de inoculação

0.37

Genotipos dentro de épocas

0.53

Epocas dentro de genótipos

0.36

Genótipos

0,81

Epocas de inocul ação

0.40

Genotipos dentro de épocas

1,28

Epocas dentro de genótipos

0,80

Isol ados

8,12

Assepsia

3,09

I sol ados

6,83

Assopsia

2.67

Isol ados

11.14

Assepsia

4,35

Mótodos

2,80

Assepsia

$1, \infty$

Mótodos dentro de assepsia

4,80

Assepsias dentro de método

3,32

Assepsia

3,54

Assepsia

4,18

Assepsia

5,32

Mśtodos

3,62

Assepsia

2,30

Mótodos dentro de assepsia

5.12

Assepsias dentro de método

4.14

Plantulas com sintomas (mótodo 12

0.85

Redução da emergencia (método 1 )

6,80 
Conti nuaçao

IABELAS MEDIAS COMPARADAS DMS

\begin{tabular}{|c|c|c|}
\hline 20 & Plantulas com sintomas cmotocu as & 1.18 \\
\hline 20 & Redução da emergencia (método a) & 11,22 \\
\hline 20 & Plantulas com sintomas (método 3) & 0,84 \\
\hline 20 & Redução da emergéncia (método 3) & 9.85 \\
\hline 2 & Plantulas com sintomas (mótodo 1 ) & 0,87 \\
\hline 2 & Reduçáo da emergencia (metodo 1 ) & 8,08 \\
\hline 21 & Redução da emergenciâa (mátodo 2) & 5,60 \\
\hline 21 & Plantulas com sintomas (método 3 ) & 0,78 \\
\hline 2 & Redução da emergencia (motodo 3 ) & 0,52 \\
\hline $2 a$ & Sementes mortas (ramulose) & 8,55 \\
\hline 22 & Radiculas apodrecidas (ramulose) & 11.13 \\
\hline 22 & Incidancia total (ramulose) & 15,75 \\
\hline 2 & Somentes mortas (antracnose) & 7,51 \\
\hline 20 & Radiculas apodrecidas (antracnose) & 10,10 \\
\hline ר & Incidencia total (antracnose) & 10,04 \\
\hline רמ & Plantulas com sintomas (ramulose) & 0.76 \\
\hline & Redução da emergencia (ramulose) & 12.04 \\
\hline & Plantulas com sintomas (antracnose) & 0,54 \\
\hline & Reduçao da emergencia (antracnose) & 14.02 \\
\hline
\end{tabular}

- Valores referentes as Tabelas 2 a 5 , para comparar dados reais e referentes as demais, para comparar dados transformados. 